
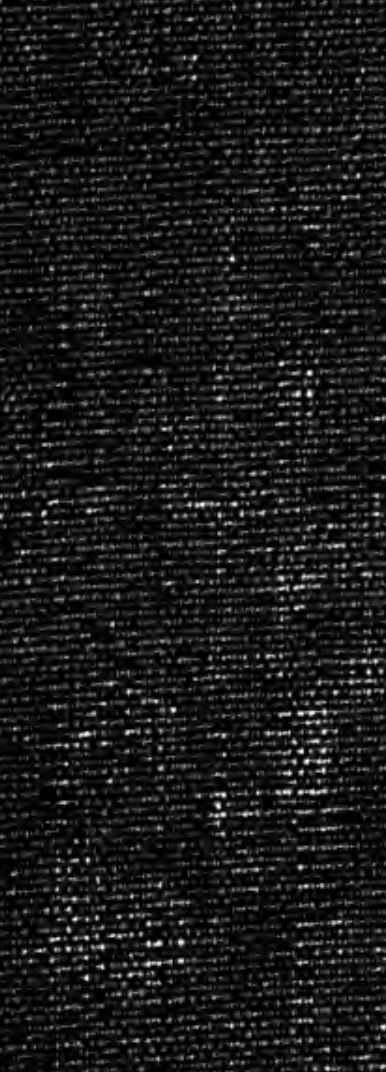

$+\cdots$

X.t.

$+2$

$2=$

सtom

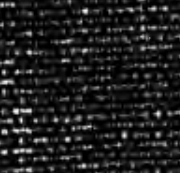

T.t.

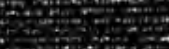

सhe

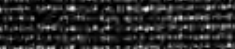

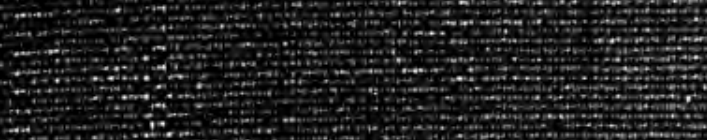

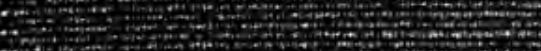

$x+2+2+2+2+2$

$+1+2+1$

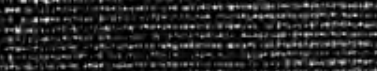

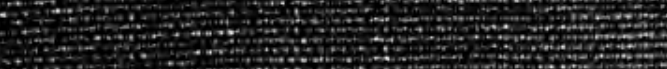

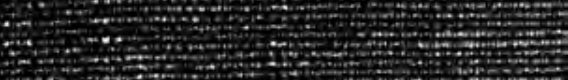
$4+4+2+2=$ $4+4+2+2+2$ TI

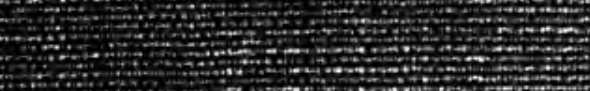

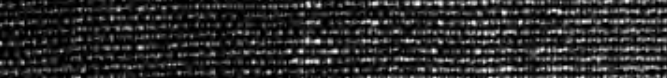

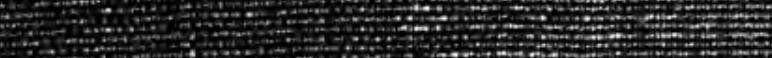

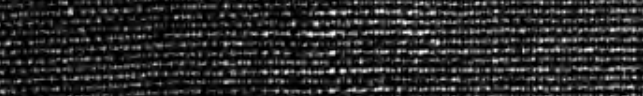

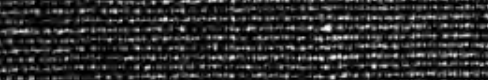
$40+2+2+2=$ $4+7+2+2+2=$

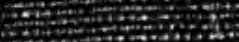

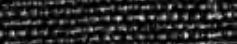




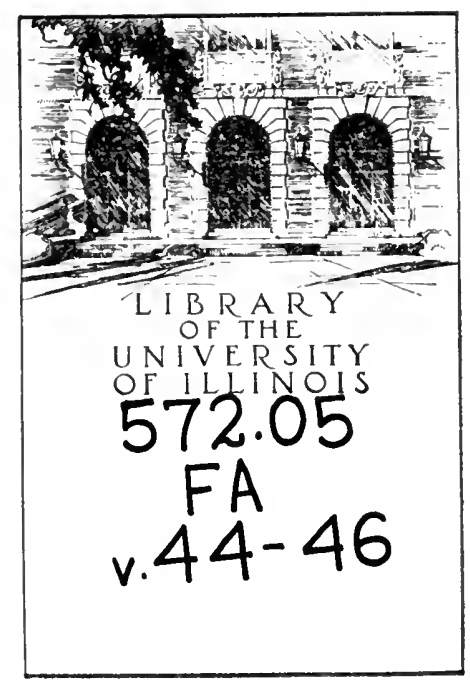


Return this book on or before the Latest Date stamped below.

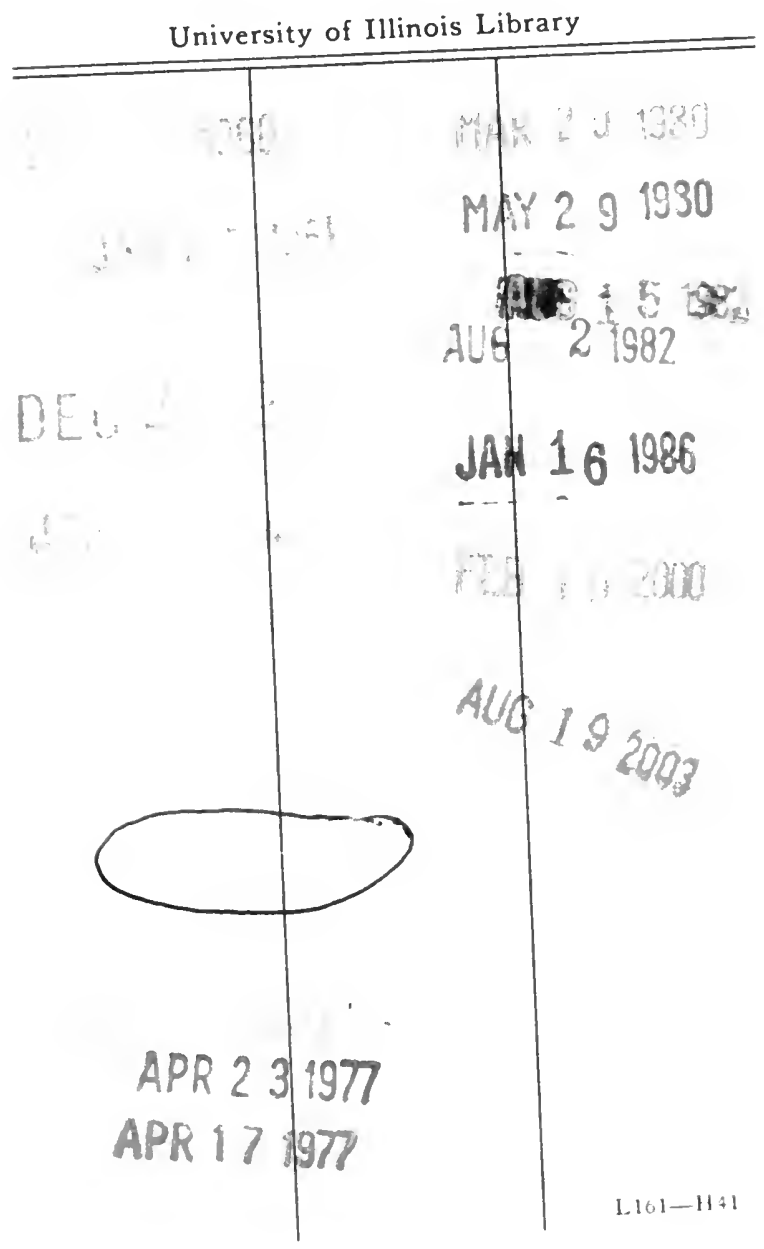





OLD AKKADIAN INSCRIPTIONS IN

\title{
CHICAGO NATURAL HISTORY MUSEUM
}

\author{
Texts of Legal And Business InTerest
}

\author{
IGNACE J. GELB
}

FIELDIANA: ANTHROPOLOGY VOLUME 44, NUMBER 2

Published by CHICAGO NATURAL HISTORY MUSEUM JUNE 30,1955 



\section{OLD AKKADIAN INSCRIPTIONS IN}

CHICAGO NATURAL HISTORY MUSEUM

TEXTS OF LEGAL AND BUSINESS INTEREST 



\section{OLD AKKADIAN INSCRIPTIONS}

IN

\section{CHICAGO NATURAL HISTORY MUSEUM}

\section{Texts of Legal and Business Interest}

IGNACE J. GELB

Professor of Assyriology, The Oriental Institute

The University of Chicago

FIELDIANA: ANTHROPOLOGY VOLUME 44, NUMBER 2

Published by

CHICAGO NATURAL HISTORY MUSEUM

JUNE 30,1955 
PRINTED IN THE UNITED STATES OF AMERICA BY CHICAGO NATURAL HISTORY MUSEUM PRESS 


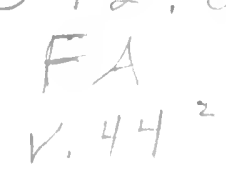

\section{Preface}

It is an old and well-known story that not alone the ancient tells of the Near East, but also our modern museums are fertile soil for the would-be discoverer of antiquities. Dug up from their ancient resting place and shipped along with a host of other objects to a museum, valuable items are sometimes stored away and forgotten for years until a lucky stroke of fortune brings them to light again.

The rediscovery of the now famous Babylonian Chronicle telling of the fall of Nineveh is a case in point. Excavated and brought to the British Museum in London toward the end of the last century, it lay hidden and unrecognized for years before it was finally brought out of its oblivion and published in 1923. Immediately it became evident that this long-lost document was of fundamental importance for the correct understanding of the historical events in the last days of the Assyrian Empire.

A similar discovery, though not of such epoch-making proportions, has been made in Chicago Natural History Museum. Shortly after the first World War the late Lieutenant Colonel J. H. Patterson, D.S.O., British Army of Occupation in Iraq, purchased a collection of cuneiform tablets from an Arab at Babylon. In 1925 he presented these tablets to the Museum. There they remained in oblivion until they were found in the latter half of 1936 by Mr. Richard A. Martin, at that time Curator of Near Eastern Archaeology, now Curator of the Department of the N. W. Harris Public School Extension, who then requested me to investigate the collection and ascertain its importance.

From the very first there has never been any question about the importance of the collection. The tablets are inscribed in a dialect of the Old Akkadian language and date back over four thousand years, almost to the very beginning of written history in Mesopotamia. Their importance is immediately apparent from several points of view.

In the first place, the texts provide a most important source of material for the study of the oldest Akkadian dialect. At the same time they make possible the clarification of many problems con- 
nected with the reconstruction of Proto-Semitic. The texts likewise greatly further our understanding of the development of social institutions in the Near East, for their subject matter is largely legal and administrative in nature. Containing, as they do, many words attesting to the existence of certain tools and implements used in industry and agriculture, the texts shed light on these activities of the ancient Akkadians as well. And, finally, the personal names mentioned in the texts help in the reconstruction of the ethnic background of the area in which the tablets originated.

Contrary to the normal procedure in text publications of this sort, the tablets are here presented in the form of photographs rather than in autographed copies. Since Old Akkadian texts are usually written in a clear, legible script, it is hoped that this will inflict no hardship upon the reader. The plates show the tablets in their actual size.

Elsewhere in this monograph (pp. 169ff.) it is suggested that the tablets of the Museum ultimately originated in the region of the Diyala River, east of the Tigris. Since almost no tablets of the Old Akkadian period from this region have as yet been made public, it is more than fortunate that I have had access to materials from the Diyala region in the Oriental Institute of the University of Chicago. They have been most useful for comparison with the Museum tablets. To Professor John A. Wilson, the past Director of the Oriental Institute, I owe a debt of gratitude for his kind permission to use this material in the present monograph.

To Colonel Clifford C. Gregg, the Director of Chicago Natural History Museum, I wish to express my thanks and gratitude for giving me the opportunity to study the collection and for approving its publication by the Museum press. Both Dr. Paul S. Martin, Chief Curator of Anthropology in the Museum, and Mr. Richard Martin have been helpful in technical matters pertaining to the publication of this study. Professors Frederick W. Geers and Thorkild Jacobsen of the Oriental Institute were kind enough to read the manuscript and offer valuable suggestions. To each of these scholars I express my sincere appreciation of their kind help.

The manuscript of the work here presented had been completed in 1941, when several conditions, all indirectly evolving from our entry into the Second World War, interrupted its publication. In the few years after the war my preoccupations with the administration of the Chicago Assyrian Dictionary project and with the publication of the Oriental Institute Diyala tablets (issued in the mean- 
time in my Sargonic Texts from the Diyala Region [Chicago, 1952]) caused a further delay in bringing the Museum project to a speedy and successful conclusion. This delay was rather fortunate in one respect, however. A thorough study of the Oriental Institute materials enabled me to solve a number of difficult problems in the Museum texts, which were not clear to me before.

December, 1954

I. J. GELB 



\section{Contents}

Notes on Transliteration _. . . . . . . . . . . 167

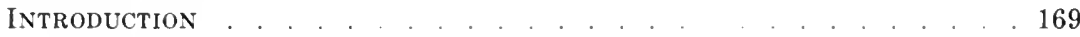

The Tablets . . . . . . . . . . . . . . . . . 169

Date and Provenience . . . . . . . . . . . . . . . 169

Contents . . . . . . . . . . . . . . . . 174

The Writing . . . . . . . . . . . . . . . 176

The Language . . . . . . . . . . . . . . . . . . 179

The Culture . . . . . . . . . . . . . . . 180

Tables of Measures . . . . . . . . . . . . . . . . 184

Transliterations, Translations, and Notes . . . . . . . . . . 186

Indices of Proper Names Found in the Texts . . . . . . . . . . . . 324

Personal Names . . . . . . . . . . . . . . . . . 324

Divine Names . . . . . . . . . . . . . . . . . . . . . 333

Geographic Names .. . . . . . . . . . . . . . 333

Indices of Text and Museum Numbers . . . . . . . . . . . . . 335

Abbreviations of Books and Periodicals . . . . . . . . . . . . 336 



\section{Notes on Transliteration}

Akkadian words are transliterated in italics, with doubtful elements in roman. Sumerian words and signs are transliterated in roman capitals, with doubtful elements in italic capitals. Doubtful elements in the English translation are in italics.

All syllabic signs have been transliterated with their first and most common value. Thus, the form taprus is transliterated as written, da-ap-ru-us, and not as tá-ap-ru-us. Signs with the initial sibilant $s$, as $s a, s i$, su, etc., are transliterated as such and not as $\check{s} a_{\mathrm{x}}, \check{s} i, \breve{s} u_{\mathrm{x}}$, respectively, in spite of my belief, expressed in $A J S L$ LIII (1936/37) 34, that the Old Akkadian written $s$ was pronounced as $\check{s}$. This has been done partly to avoid a superabundance of diacritic marks and partly in order not to anticipate ThureauDangin's new and revised system of transliteration before it is accepted by all the scholarly world. Wherever diacritic marks were absolutely necessary, as in distinguishing such partially homophonous signs as those for $a \dot{a}, \grave{u}, g i_{4}, m \dot{a}$, Thureau-Dangin's system of transliteration as expounded in his Le syllabaire accadien (Paris, 1926) and Les homophones sumériens (Paris, 1929) has been followed.

The so-called logograms or word signs appear transliterated with their Sumerian values, owing to the numerous difficulties in ascertaining the correct Akkadian forms for the early period in which these tablets were written. Of course, it would have been easy and safe to transliterate such signs as Sumerian ARÁD with wardum, or Sumerian DINGIR with ilum. But the problem of Sumerian EN, for instance, is another matter. Is its Old Akkadian equivalent be $e^{\text {lum }}$ or bêlum? Or, to cite another example, is Sumerian DUMU to be transliterated by marum, merum, or by a different form? Because of these and other similar difficulties all Sumerian logograms in the texts have been retained as such in the transliterations. However, in the English translations, whenever possible, the Sumerian logograms occurring in personal names have been replaced by their Akkadian equivalents. 
The following symbols are used:

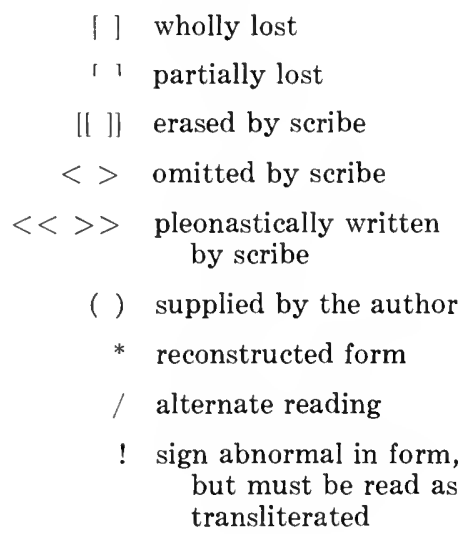

$<$ develops out of

$>$ develops into

- $x$ a single lost or unreadable sign

lost or unreadable signs, number uncertain or unessential

^ long vowel resulting from contraction (as in dînum, dânum, $i d \hat{i} n, r a b \hat{\imath})$

- morphologically long vowel (as in mahărum, mãhir )

Very few determinatives are used in our texts: ${ }^{\mathrm{d}}$ for divine names, GIŠ for trees and wooden objects, KUŠ for objects made of leather, and ${ }^{\text {TUG }}$ for garments. The determinative ${ }^{\mathrm{KI}}$ is used after geographic names. In the discussions referring to tablets of later periods also the determinatives ${ }^{\mathrm{m}}$ for masculine and ${ }^{\mathrm{f}}$ for feminine personal names and ${ }^{\mathrm{URU}}$ for cities are found. The transliteration of determinatives here followed is provisional; a revision of the whole system is badly needed. 


\section{Introduction}

\section{THE TABLETS}

Originally the collection comprised fifty-four tablets bearing the Field Museum numbers 229201-54. Later, when no. 229229 was joined to no. 229225, this total was reduced to fifty-three.

There are now no fragments in the collection. All the tablets are complete, except for some which have chipped edges. The majority are well preserved, and the signs on them are easily readable; some are, however, so badly worn in spots that successful decipherment is impossible.

A few of the tablets were badly incrusted with salt crystals, which, however, disappeared upon chemical treatment. Most of the tablets range in color from light brown to red. Some of them are blackish, and these are usually more elegant in appearance than the tablets in other colors.

The tablets vary considerably in size. The largest, no. 229201, is about $12 \mathrm{~cm}$. long and about $8 \mathrm{~cm}$. wide, while the smallest, no. 229208 , is only about $4 \mathrm{~cm}$. long and less than $3 \mathrm{~cm}$. wide. Normally, however, the tablets vary but little in width; the greatest variation is in length. In other words, the small tablets approach the shape of a square, while the larger ones are rectangular, with their length often twice their width.

On many tablets, particularly on good specimens, obverse and reverse exhibit distinctly different profiles, that is, a flat obverse and a convex reverse. But this is not always the case; as a result, in some instances, notably in the tablets containing lists, it is difficult to distinguish the obverse from the reverse.

\section{DATE AND PROVENIENCE}

It has already been stated in the Preface that the tablets here published did not come to the Museum by way of a scientifically controlled excavation. Since they were obtained through private channels and without any definite information about their 
provenience, ${ }^{1}$ only internal evidence offered by the tablets themselves can be used in an attempt to reconstruct their ultimate origin.

Even the most superficial inspection of the sign forms, of the orthography, and of the language used in the tablets of the Museum collection leaves no doubt that they belong to the Old Akkadian period. Since none of the tablets in this collection are dated, it is of course impossible to assign them with any degree of certainty to any single king of the Old Akkadian dynasty. However, our tablets exhibit so many resemblances to the published and unpublished tablets bearing dates of Narâm-Sin and Šar-kali-šarrī in other collections that it is permissible to assume that ours likewise were written about the time of these two Old Akkadian kings, or about 2261-2199 B.C. ${ }^{2}$ The newly published tablets from Nippur dated to Sargon, the first king of the Old Akkadian dynasty, ${ }^{3}$ show so many differences in orthography ${ }^{4}$ that they may be safely excluded from comparison.

So much for the date of the tablets. In order to ascertain their provenience it is necessary to study several larger groups of excavated tablets of similar type, also from the Old Akkadian period, and to compare them with the Museum collection.

In the land of Sumer in southern Babylonia several sites, such as Lagaš, ${ }^{5}$ Adab, ${ }^{6}$ and Nippur ${ }^{7}$ as well as some others of less importance, have yielded a considerable number of Old Akkadian tablets. The main characteristic of the texts from this region is that they

1 The Arab who sold the tablets to Lieutenant Colonel Patterson (see the Preface) told him that they had been dug up "somewhere southeast of Babylon." Anyone who has had any experience with purchased oriental antiquities knows how unreliable such general statements from the natives can be.

${ }^{2}$ Owing to present uncertainties concerning the older chronology of Mesopotamia, an exact date for the reigns of these two kings cannot be given. V. Christian and E. F. Weidner's approximate date of 2448-2387 B.C. for these two kings, proposed in $A O F$ V $(1928 / 29) 140$, and Thorkild Jacobsen's date of 25362474 , proposed in $A S$ no. 11, Table II, seem to be too high. The dates here reconstructed are based on Jacobsen's figures minus 275 years required by the "low" chronology now generally favored.

${ }^{3}$ A. Pohl, TMH V 85, 151, 181.

${ }^{4}$ In this connection note especially the characteristic forms of the $\breve{S}$ and DA signs. The tablets dated to Sargon have the first vertical wedge written with an upward stroke, and they are thus linked epigraphically to the Pre-Sargonic period. Tablets written after Sargon show this vertical wedge made with a downward stroke. Pohl's statement, op. cit., p. 7, on the forms of these two signs should be corrected in respect to Sargon's period.

${ }^{5}$ Published chiefly in F. Thureau-Dangin, RTC and ITT I; H. de Genouillac, ITT II Part 2 and V.

${ }^{6}$ D. D. Luckenbill, OIP XIV.

${ }^{7}$ Chiefly in G. A. Barton, PBS IX Part 1 and A. Pohl, TMH V. 
employ very little Akkadian (being written mostly in Sumerian) and that the persons occurring in them bear predominantly Sumerian, not Akkadian, names.

In northern Babylonia, in the land of Akkad, relatively few sites have been excavated. Our scarce material for the Old Akkadian period in this area comes chiefly from Sippar ${ }^{1}$ and Kiš. ${ }^{2}$ From the region of Kiš comes the famous Obelisk of Maništušu. ${ }^{3}$ As expected, the Akkadians predominate in this area.

Southeast of Babylonia lies Elam with its capital, Susa, excavated by the French. From there we have several dozen Old Akkadian tablets, ${ }^{4}$ written for the most part in Akkadian. The population seems to have been also chiefly Akkadian, with some Sumerian and native Elamitic admixture.

North of Babylonia, in the region of the Diyala River, several sites have recently been excavated by expeditions of the Oriental Institute of the University of Chicago. Of these, Tell Asmar, Khafaje, and Tell Agrab have furnished a large amount of valuable material from the Old Akkadian period. The tablets are normally written in Akkadian and contain almost exclusively Akkadian names.

Several groups of Old Akkadian tablets come from the north in Assyria and Mesopotamia proper. The largest group consists of tablets excavated at Gasur, later called Nuzi, situated east of the Tigris in the neighborhood of Kirkuk. ${ }^{5}$ Much smaller collections come from Assur, the ancient capital of Assyria, ${ }^{6}$ and from Chagar Bazar $^{7}$ and Tell Brak, ${ }^{8}$ two small sites south of Mardin in central Mesopotamia. The language of the texts is Akkadian. The great majority of the personal names are Akkadian, with a few sporadic examples of Sumerian names. A number of other personal names, whose linguistic affiliations are difficult to identify but which are clearly non-Akkadian and non-Sumerian, are also found in the texts.

On the basis of the facts presented above we may try to reconstruct the ethnic background in the region of the Tigris and Eu-

${ }^{1}$ H. V. Hilprecht, $B E$ I pls. VIff.

${ }^{2}$ L. C. Watelin and S. Langdon, Excavations at Kish III (Paris, 1930) pl. XI, W. 1929, 160 and Langdon in RA XXIV (1927) 90 and 96 (letters).

${ }^{3}$ V. Scheil, Mém. II.

${ }^{4}$ Chiefly in V. Scheil and L. Legrain, Mém. XIV.

${ }^{5}$ T. J. Meek, HSS X.

${ }^{6}$ See the remarks by A. Falkenstein in Zeitschrift der Deutschen Morgenländischen Gesellschaft XC (1936) 714 and n. 2.

' C. J. Gadd in Iraq IV (1937) 178 and 185.

${ }^{9}$ Idem in Iraq VII (1940) 42, 60f., and 66. 
phrates in the Old Akkadian period. To be sure, the following ethnic picture is drawn solely from our knowledge of the languages used in the texts and of the linguistic affiliations of the personal names found in them, but, lacking any other indications, this must suffice for the present.

In Sumer, in southern Babylonia, we find the Sumerians with a limited admixture of Akkadians, while in Akkad, in northern Babylonia, and in the Diyala region, we find a small Sumerian element among the predominantly Akkadian population. Elam, in the southern wing, presents a mixture of Akkadians, Sumerians, and natives. To the north, around Gasur, and also to the west of the Tigris, the Akkadians predominate, but they occur there together with a certain non-Akkadian and non-Sumerian stock.

To return to our original inquiry, it may now legitimately be asked how the Museum collection fits into this picture. As has already been mentioned, the language employed in the Museum texts is Akkadian throughout, and the personal names mentioned are largely good Akkadian, with scarcely any names of Sumerian or foreign origin.

Thus, it is self-evident that, lacking as it does almost all trace of a Sumerian element, the population represented by the Museum tablets must have lived in a region outside of southern Babylonia. Similarly, the tablets cannot have originated in or near Elam, since no Elamitic names have been discovered in our texts. In like manner, the far north may be eliminated as their possible home, because the texts contain no foreign, that is, non-Akkadian or non-Sumerian, elements.

This leaves only two possibilities, the land of Akkad and the Diyala River region. It so happens that the texts from both of these areas, like those of the Museum tablets, indicate a thoroughly Akkadian population. The question then arises, which of these is the one and only possibility? To answer it we must turn to the geographic and divine names in our texts.

Turning first to the largest and perhaps the most important tablet, no. 33, we find that it contains lists of various objects and provisions delivered to certain places. Among the geographic names mentioned are Ibrime (written $I b$-ri-me), Banga (written $B a n-g a^{\mathrm{KI}}$ ), and Kite (written $K i$-d $\dot{e}^{\mathrm{KI}}$ ). Of these, Banga (the possibilities are $\mathrm{B} / \mathrm{pang} / \mathrm{k} / \mathrm{qa}$ ) is unknown to me from outside sources. But the other two cities, Ibrime and Kite, are well attested in the inscriptions 
from Tell Asmar in the Diyala River region. ${ }^{1}$ Since geographic names mentioned in economic texts usually refer to localities within a small area around the site where the texts originated, we may legitimately assume that at least no. 33 of the Museum collection originated at some site in the Diyala River region.

However, the fact that one tablet comes from a certain area does not mean that the whole collection must necessarily have originated there. It must be borne in mind that the collection was purchased from an Arab, who could easily have obtained the tablets from several different sources.

Here can be brought to bear on our investigation one of the divine names found in the Museum collection, namely Tišpak. This god is found in our collection in the theophorous names $P u$ Tišpak (no. 4:4? and 10) and Warad-Tišpak (no. 13:2) as well as in the phrase "gate of Tišpak," in the texts nos. 7:26 and 51 rev. $x+2$. Tišpak is the chief god of Ešnunna (modern Tell Asmar) and occurs frequently in texts of all periods from Diyala region. ${ }^{2}$ This method of identification may be applied in linking several other tablets of the Museum collection with the Diyala region.

Further evidence favoring the unity of origin of the collection is provided by the names of persons involved in the texts. Thus, the name Ginunu is found on ten tablets, and in at least seven cases it denotes evidently the same person, judging by the similarity in type of the documents in which he is concerned. Also, the recurrence again and again of the same witness names in the legal business transactions favors the assumption that the tablets represent archives of one or more private individuals living in the same locality.

It is noteworthy also that the personal names in the Museum collection find more correspondences in the tablets from the Diyala region than in any other group of texts. Elsewhere in this study are discussed the correspondences between certain names of rare occurrence. To these might be added many more correspondences between common names. Often the similarity is a striking one. For

${ }^{1}$ See notes to no. $33: 25,32$, and 50 .

${ }^{2}$ See the study of Jacobsen in H. Frankfort, T. Jacobsen, and C. Preusser, Tell Asmar and Khafaje. The First Season's Work in Eshnunna, 1930/31 ("Oriental Institute Communications," no. 13 [Chicago, 1932]) pp. 51-59. In scanning through the Old Akkadian material at my disposal I could find no reference to Tišpak outside of the Diyala River region. The occurrence of Tišpak in the personal name $A$-bi-d Tispak in a tablet published by H. F. Lutz in University of California Publications in Semitic Philology IX pp. $204 \mathrm{f}$., no. 83 means simply that that tablet, too, comes from the Diyala region, as best indicated by the occurrence of Išnun (=Ešnunna) ibid. l. 46. 


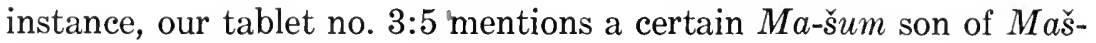
tum; on a tablet from Tell Asmar (published in MAD I 96: 4f.) two men named $M a$-šum and $M a$-áš-tum appear side by side. Evidence of this character is naturally not of decisive importance, but it can and should prove very profitäble when added to other considerations of greater weight.

The language of the Museum texts is Akkadian, and to all intents and purposes it is identical with the language employed in the tablets from the Diyala region. From the grammatical standpoint, the only difference lies in the use of the subjunctive in $-a$ (discussed under no. 1:12), not found as yet outside of our collection.

When all the facts are marshaled together, the evidence pointing toward the Diyala River region as the place of origin of the Museum collection seems convincing; but the exact locality from which it comes within this region must remain unknown for lack of sufficient comparative material.

\section{CONTENTS}

Like most texts from the Old Akkadian period, those in the Museum collection are predominantly of legal, business, and administrative character. There are probably also some school tablets and two private letters. There are no tablets of a literary, religious, or historical nature.

Perhaps the most important group of tablets in the collection is that of the legal documents (nos. 1-19). The main external characteristic of these is the appearance of witnesses. As P. Koschaker ${ }^{1}$ observed, throughout the whole of Assyro-Babylonian history the legal business document was a witnessed document. If one recalls that among the entire Gasur material are found only two legal documents with witnesses ${ }^{2}$ and that elsewhere in this period this class of documents is very sparsely represented, it is easy to see that the legal documents in our collection form a welcome and important addition to our knowledge.

The documents in this class can be divided into several smaller groups. The first and largest group (nos. 1-7) consists of legal transactions of the type: "These are the witnesses (to the fact) that A gave (sold etc.) something to B." The second group (nos. 8-11) contains declarations with the usual phraseology of the type: "These

${ }^{1}$ In $O L Z$ XXXIX (1936) 150 .

${ }^{2}$ Discussed ibid. col. 150. 
are the witnesses (to the fact) that A said (swore, etc.) thus to B." 1 Interesting is no. 8 , in which both a declaration by a certain man and a transaction are attested by witnesses. Nos. 12 and 14 mention the witnesses, but the tablets are in such bad condition that it is impossible to determine in which group of documents they should be classed. The witnesses are usually mentioned at the beginning in the text, but sometimes, as in nos. 4 and 7, they are listed at the end. The variation shows that the form of legal documents had not yet become firmly fixed in this period.

The texts of nos. 15-19 have one characteristic in common. They first enumerate the names of certain persons and then describe the transaction made between certain other persons. I do not know how else to interpret these inscriptions but to consider the names of the men listed at the beginning of the inscription as being those of witnesses to the transaction. The omission of the word "witnesses" (invariably included in nos. 1-14) in these texts should not be too difficult to explain in view of the general brevity of the inscriptions in question. Observe that in all those cases in which the word "witnesses" is omitted even the verb describing the transaction is lacking. Thus in no. 15 it is stated that the barley of $\mathrm{A}$ (is) with $\mathrm{B}$, in no. 16 that $\mathrm{A}$ (received) barley, in no. 17 that A (gave) barley to B (and similarly in nos. 18 and 19). The omitted words can usually be surmised. Again the lack of a firmly established legal phraseology is evidenced by these examples.

Next in order come the administrative texts (nos. 20-39), in which likewise several classes are represented. No apparent order or formula governs the composition of these documents. Usually absolute brevity of expression prevails. Certain texts are so terse as to give the impression that they are private memoranda. Also the personal tone ("I gave this and this") of some of the texts (as in nos. 21 and 35) tends to support this supposition. It is interesting to compare tablet no. 32 , recording the loan of a lamb and of a certain amount of barley to two individuals, with tablet no. 15, attested by witnesses and referring to a loan of barley by one person to another. While the first text is an administrative document or a memorandum

${ }^{1}$ With but slight modifications in form both groups of documents are well represented in the later periods. See Koschaker and Ungnad, Hammurabi's Gesetz VI (Leipzig, 1923) 153, n. to no. 1769 (for Old Babylonian); Koschaker, Neue keilschriftliche Rechtsurkunden aus der El-Amarna-Zeit "Abhandlungen der philologisch-historischen Klasse der Sächsischen Akademie der Wissenschaften" XXXIX, no. 5 [Leipzig, 1928]) p. 23 (for Middle Babylonian); M. San Nicolò and A. Ungnad, Neubabylonische Rechts- und Verwaltungsurkunden I (Leipzig, 1935) $607 \mathrm{ff}$. (for New Babylonian). 
for private use, the other is a legally binding business document because it is witnessed.

The tablets nos. 20-24 concern mainly the distribution-of barley among various individuals. Such documents are found frequently in all periods. Two rather important tablets, unfortunately badly preserved in spots, give us the dimensions of certain fields (nos. 25 and 26). Three tablets enumerate personal names, evidently those of workers who were supposed to perform certain services for certain other persons (nos. 27-29). One tablet lists persons designated as ŠEŠS.SAL and $k u l u^{\top} \bar{u}$ (no. 30 ). Another discusses certain property in Agade (no. 31), and still another refers to the loan of a lamb and of a certain amount of barley to two individuals (no. 32).

Perhaps the most important group of tablets after the witnessed documents (nos. 1-19) is the group of administrative texts containing lists of various objects such as metals, skins, and provisions, sometimes accompanied by the names of the persons for whom they were destined and sometimes not (nos. 33-39). The importance of these tablets lies chiefly in the extensive vocabulary for provisions and various objects of daily life employed in them.

Nos. 40-44 are difficult to interpret. For the most part it is not so much that they are difficult to read but that they are so difficult to understand. Some of them may possibly be lists like nos. 33-39, discussed above; others may be school tablets. The most troublesome of this group is no. 40 , the obverse of which is perfectly readable yet completely unintelligible.

Nos. 45-51 comprise tablets which are either so badly preserved that hardly a word can be read with safety, or well preserved in general but so badly damaged in some essential parts of the inscription that their character cannot be ascertained.

Finally, at the end of the volume are published two private letters from one individual to another (nos. 52 and 53). Because of their richness in vocabulary and grammatical forms they are valuable for the reconstruction of the Old Akkadian dialect. But like most ancient letters they also present their difficulties of interpretation. The introductory formula in our letters is the same as that in other letters of the Old Akkadian period: "Thus (says) A to B." No salutation or date ever accompanies the Old Akkadian letters.

\section{THE WRITING}

The texts are in cuneiform writing, developed by the Sumerians and adapted by the Akkadians for writing their own language. 
The epigraphic and orthographic features of the Museum tablets are identical with those known from other tablets of the same period. Local peculiarities occasionally manifest themselves, but in general one system of writing prevails during this period and throughout the entire area from Susa in the south to Chagar Bazar in the north.

This uniformity in writing is evidenced most strikingly in the standardization of the sign forms. Thus, a person well versed in Old Akkadian inscriptions from Susa, for example, would encounter no difficulty in reading the signs on the tablets in our collection. Slight deviations are observable in the writing of some signs, such as ŠUBUR (cf. the occurrence in nos. $33: 15$ and $39: 1$ with the normal forms in no. 33:20, 23, 55), DUN (nos. 16:2, 37:6, 38:3), ÙR (no. 33:3 and 54), DUBBIN (no. 33:34). Tablet no. 34 uses several signs which deviate in form from the normal usage (MU, ŠAKAN, TÚG, GÍD).

From the esthetic point of view the Old Akkadian writing is perhaps more beautiful than that of any other period. In regularity of form, attention to detail, and elegance of appearance it can hardly be matched in all the long history of cuneiform writing. ${ }^{1}$

The so-called phonetic indicators are used very sparsely in our texts. See, for example, $\mathrm{AB}+\overline{\mathrm{A}} \breve{S}-b u-u t, \mathrm{AB}+\overline{\mathrm{A}} \breve{S}-b u-t u m$, and $\mathrm{AB}+$ $\bar{A} \breve{S}-b u-z u$, discussed under no. 1:9 (but also $A B+A \bar{A} \breve{S}$ alone is found),

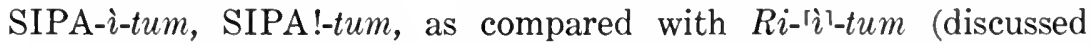
under no. 6:4), DUMU- $a$ in no. $2: 12$ (as against the commonly used DUMU), and ŠÁM-me (no. 10:9) or ŠÁM-mu-su (no. 33:62).

As compared with other tablets of similar type and from the same period, the tablets in the Museum collection employ phoneticsyllabic writing to a much greater degree. The order of signs in the syllabic writing is firmly established, and deviations from this order are no longer permitted in the Old Akkadian period.

The lines of writing are regularly separated by horizontal rulings. The text normally reads from top to bottom of the obverse, around the lower edge, down the reverse, then along the left edge and finally the right edge of the tablet. Variations occur, of course. Sometimes only the obverse is inscribed. Often, too, only obverse and reverse are inscribed and the lower edge is left blank. Or the left edge may

1 It may be mentioned here that this regularity of form conveniently enables the decipherer to read badly preserved signs, even when their outlines alone are visible and all details are broken away. 
be used but not the upper edge. Occasionally, long lines on the obverse may run onto the right edge of the tablet.

Sometimes, when the sense of an inscription is obscure, it is difficult to determine which side is the obverse and which the reverse. In some cases, the shape of the tablet itself furnishes a clue in that the obverse is usually flat and the reverse convex. ${ }^{1}$ This failing, it may be possible to ascertain which is the obverse by observing the position of the left edge. Judging from such tablets as nos. $7,8,10,37$, and 40 , whose arrangement is well fixed, the writing on the left edge begins at a point near the left bottom of the obverse. ${ }^{2}$

Only one tablet in the entire collection (no. 33) is divided into columns, perhaps because it is the only one large enough to require columnar arrangement. In the Sargonic period large tablets pertaining to administration are arranged in columns very frequently.

Some of the tablets have blank spaces between one section of the inscription and the next. Thus in no. 3 a list of the names of four men is divided by a blank space from the description of the business transaction, which those four men witnessed. Similar observations can be made on the basis of nos. $1,9,15,30,36$, and in some other, less clear cases. Uninscribed spaces of this type serve the same function as our modern division into paragraphs. Sometimes double horizontal rulings are used to separate sentences, as in no. 33.

In the Pre-Sargonic period numbers are expressed by forms which are not far removed from the old pictorial stage of cuneiform writing. By the time of the Third Dynasty of Ur, however, these signs had already developed the forms which they were to bear in all the succeeding stages of cuneiform writing. The Old Akkadian period, being intermediate between these two periods in time, therefore represents the transitional stage in the writing of numbers. Thus in the tablets of the Museum collection both old and new forms appear. This is best shown by text no. 36 , in which 30 SÍG MA.NA is written with the old type of numbers in line 18 and with wedges in line 26. ${ }^{3}$ Similarly, the number "one," used as the personal name determinative, ${ }^{4}$ is written indiscriminately in the old and in

${ }^{1}$ See also above, page 169.

${ }^{2}$ It is to be noted that this was not necessarily the rule elsewhere, and perhaps not without exception even in our collection. Thus both of the examples from Susa (Scheil and Legrain, Mém. XIV 7 and 45) and three of the Gasur tablets (Meek, HSS X 6,9,162) exhibit the same left edge position as do our tablets, while one Gasur tablet (ibid. no. 5) does not.

${ }^{3}$ Similar variations appear also in no. 26.

${ }^{4}$ On this see later, pages $324 \mathrm{f}$. 
the new form (cf. for example, no. 6 with no. 8). By and large, however, the old type of writing numbers predominates in the Sargonic period.

It may be pertinent to discuss here some other orthographic features in which the Museum tablets diverge from the general practices of the period.

Double consonants are usually written singly in Old Akkadian. But there are several exceptions to this rule in our tablets: Al-lu-lu (no. 25:4), al-lum (no. 33:16), Al-lum (no. 9:2), at-ti-kum (no. 8:13; but $i$-ti-nam and ${ }^{\top} a^{\top}$-ti-šum in no. 35:10f.), $I b$-bu-bu (no. 3:11), Mim-ma-sa (no. 37:5), mim-ma-su (no. 8:14), su-tu-uh-ha-tim (no. 52:6), and te-er-ri-iš (ibid. line 8). Such cases as A-hu-li-bur-ra (no. 28:4) or Li-bur-ri-im (no. 30:5) cannot, of course, be considered as forms in which double consonants were intended (see $n$. to no. 28:4). Expression of double consonants by means of "broken" writing in such cases as $A$-dam- $u, A$-nin- $u, D a r-e-t u m$, and Dar-u-ma is discussed under no. 18:20.

Thureau-Dangin long ago established the rule that the Old Akkadian written $\check{s}$ usually corresponds to Proto-Semitic $\underline{t}$, while written $s$ corresponds to Proto-Semitic śs and $\check{s}^{1}$ In the Old Akkadian period the two consonants $\breve{s}$ and $s$ are normally well distinguished; only in the later period of the Third Dynasty of Ur are these two sounds frequently interchanged.

In contrast to this general rule, the texts in the Museum frequently show the interchange of writings with $s$ and with š: Su-ni-tum

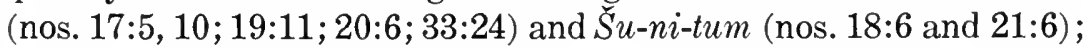
si-tim (no. 10:9), 'si'-tum (no. 53:7), and ši-tum (no. 9:27, not sure); $a l-s u$ (no. 7:27), mim-ma-su (no. 8:14), É-ti-su $u_{4}-n u$ (no. 36:29), and ma-ha-ar-šu-nu (nos. 8:16;12:16). ${ }^{2}$

\section{THE LANGUAGE}

The language used in the Museum texts is Akkadian, or AssyroBabylonian. To be more specific, it is a local Diyala dialect of Old Akkadian, which differs but slightly from the Old Akkadian spoken elsewhere.

It is impossible to give here all the characteristics of the Old Akkadian dialect as evidenced by the Museum texts. Nevertheless, some of the new and interesting facts pertaining to grammar and

${ }^{1}$ In $R A$ XXIII (1926) 28.

${ }^{2}$ For interchange of $s u$ and $s u_{4}$ ef. $i k-s u-r a$ (no. $\left.14: 30\right)$ with $i k-s u_{4}-r a$ (no. 36:9). 
vocabulary may be briefly pointed out, together with references to the more detailed discussions.

As far as the grammar is concerned, the noun shows no important irregularities. Case endings are regularly used, and mimation is always preserved. Some seeming exceptions in personal names are discussed under nos. 25:2 and 49:12. The dual is used regularly in this period, as, for example, in $a$-za-an (no. 33:5), zu-zu-la-an (no. 7:19), DUMU-a (construct state, no. 2:12), sa-ti-da (no. 49 rev. $\mathrm{x}+3$ ). The interesting fucullā $u m$ formation is discussed under no. 49. Unique and important is the use of the subjunctive ending $-a$ beside the normal ending $-u$ (discussed under no. 1:12). The verbal form eppiš (discussed under no. 53:15) is the same as that of the Old Babylonian period. The declension of the determinative-relative pronoun šu can be observed in many cases (nos. $7: 22 ; 21: 5 ; 31: 4$; 36:7; 43:7; and perhaps 44:6f.). The occurrence of quddušiš (discussed under no. 47:11) testifies to the use of the -iš formation so popular in the Old Akkadian period. In regard to phonology note the $m>n$ development discussed under no. 36:5.

The vocabulary likewise has its peculiarities. Thus, words may occur with meanings that are either completely unknown or infrequently attested in other periods. Cf. the discussions of the nouns enûm (no. 7:21), kišamarum (no. 52:7), šutuhhatum (no. 52:6), and the verbs kašărum (no. $36: 2$ ), šadādum (no. 1:12), etc.

Perhaps the most important single negative result deriving from our study of the texts is that Sumerian influence is totally lacking in them. Not a single Sumerian nominal or verbal form and not one single Sumerian legal expression is to be found anywhere in the Museum texts. This fact is in complete agreement with our conclusion that the Sumerians as an ethnic group were non-existent in the region of the Diyala River (see pp. 172ff.).

\section{THE CULTURE}

The extant texts do not furnish us with a complete, straightforward account of the government, religion, agriculture, or industry of the Diyala River region in the Old Akkadian period. But they do give us hundreds of words which are, indirectly, of great help in reconstructing the conditions under which the people of our texts lived.

It is of course self-evident that many objects used in daily life will not be found in the following description, not because they were 
not used at the time when our texts were written, but simply because the available material upon which our description is based is not comprehensive enough. Other objects are known to us from texts outside our collection. However, even if all the written material of the period were at hand, our knowledge would still be incomplete, for it does not necessarily follow that everything pertaining to the daily life would be recorded.

Social and religious conditions can be reconstructed only very sketchily owing to the inadequacy of the sources. The highest local official was the governor $\left(\mathrm{EN}_{\mathrm{x}} . \mathrm{SI}\right.$, nos. $\left.11: 14 ; 14: 9 ; 46: 2\right)$, who, to judge from what we know about his functions from elsewhere, was directly responsible to the king. The city council was composed of the elders $\left(\mathrm{AB}+\overline{\mathrm{A}} \breve{S} \mathrm{URU} \mathrm{U}^{\mathrm{KI}}\right.$, passim). The presence of a military class is attested by the occurrence of soldiers (UKU $\mathrm{U}_{\mathrm{x}} . \mathrm{US}$, nos. $47: 9 ; 52: 4$ ) and of a high officer (GAL.UKÜ, no. 12:2). Justice was dispensed by judges (DI.TAR, no. 7:27), probably - as so often in the ancient Orient - at the city gates (KÁ, nos. $7: 26 ; 51$ rev. $\mathrm{x}+2$ ), which were guarded by gate-keepers (NI.DU 8 , no. 43:13). The MAŠKIMofficial was probably the bailiff of the judge (nos. $7: 28 ; 51$ rev. $x+1$ ). It was up to the SAG.ZUG 7 official, "land registrar," to keep the official records relating to property (no. 51 rev. $\mathrm{x}+7$ ).

Temple activities are evidenced by the occurrence of several classes of priests and temple officials, such as SANGA (nos. 1:1; 18:19; 27:8), MAŠ.MAŠ (nos. $2: 6 ; 25: 1$ ), and GUDÚ (no. 8:5).

The Museum tablets in conjunction with many other sources published elsewhere show that the Old Akkadian society was mainly an agricultural one. The country outside of the cities was subdivided into estates $(\hat{\mathrm{E}})$ of various sizes owned by the king, his family and officials, by the temple, or by private individuals. The estate included serfs, who as smiths, carpenters, masons, etc. specialized in their various professions, and slaves. The estate was administered by the superintendent (ŠABRA É, nos. 44:6; 46:4), to whom were responsible the overseers (NU.BANDA, no. 4:11) and the lower-ranking foremen (UGULA, nos. 12:17; 39:11). In proportion to serfs, the number of slaves (ARÁD, passim) and slave girls (GEME, passim) is rather limited. It is interesting to note that even the latter had the privilege of serving as witnesses to legal transactions (nos. 8:4; 9:9f.; 16:2f.).

The estate provided the people with monthly rations of grain or flour, oil, and perhaps straw. The barley rations (ŠE.BA E, no. 44:13) vary from 60 QA for a grown man to 10 QA for a baby, 
with intermediate quantities of 30-40 QA for women, $30 \mathrm{QA}$ for boys, and 20-30 QA for girls. The exact data concerning rationing of barley must be obtained from sources outside our collection, but they are supported indirectly by our nos. 20,23, and 24 . The picture of a feudal society based on private property, as briefly reconstructed above, does not take account of theories that have been proposed in the past by various scholars in support of public ownership of land and of an etatistic and/or a theocratic organization of the Mesopotamian society. This very important subject should be thoroughly discussed in the near future.

The cities, besides being centers of public administration, had highly organized arts and trades. Much information can be obtained from observations of the occurrences of professions which are mentioned along with the personal names. Thus, we find bakers (MUHALDIM, no. 48:9), barbers (ŠU.I, nos. 21:2; 22:2), carpenters (NAGAR, nos. $9: 9 ; 13: 2 ; 39: 11 ; 43: 8$ ), fowlers (MUŠEN.DÜ, nos. $2: 15 ; 12: 7$ ? and $14 ; 50: 5)$, fullers ( $g a-z i-r u$, no. 51 rev. $\mathrm{x}+9$; perhaps TÚG, no. 16:7; also a female, SAL.LÚ.TÚG, no. 36:11), maltsters (LÚ.MUN ${ }_{\mathrm{x}}(\mathrm{BULUUG})$, no. 9:8), masons (i-ti-num, no. 40:16), merchants (DAM.KÀR, no. 16:4), physicians (asum in the name DINGIR- $a-z u$ ), potters (EDIN, no. 36:5), sailors (MÁ.LAH ${ }_{4}$, no. 12:3), shepherds (SIPA UDU, no. 16:6; cf. also Re'îtum among personal names), shoemakers or leather-workers (AŠGAB, nos. $43: 19 ; 44: 12 ; 45: 6 ; 48: 2)$, smiths (SIMUG, no. 44:3), and upholsterers (TÚG.DU ${ }_{8}$, no. $36: 13$ ).

The people lived in houses (É, nos. $1: 11 ; 5: 12 ; 10: 8 ; 31: 3 ; 36: 10$, $12,29)$ made of bricks $\left(\mathrm{SIG}_{4}\right.$, nos. 44:17; 45:7?; brick moulds [nalbanātum] are mentioned in no. 43:6) and logs (for the roof, GIŠ.ÙR, no. 33:3, 54, and GIŠ $u$-rí-i $[m]$, no. 39:2; cf. also GIŠ. IŠ.DE, nos. $2: 1 ; 4: 2$ ?). The houses had doors (cf. the difficult expressions discussed under nos. 33:10f.; 43:15f.) and window shutters in the form of wooden or clay grilles (naktamāt aptim, no. 41:1). What a "chair house" (É.GU.ZÉ, no. 8:18) means we do not know.

Of the various kinds of grain, barley ( ̌SE, passim) is by far the most common in the Old Akkadian period. Flour (ZÍD.ŠE and ZÍD.GU) was milled from it, and from flour bread (NINDA, passim) was prepared. Other grades or classes of barley are ŠE. UD.UD (no. 22:3) and ŠE. ${ }^{\mathrm{d} I N N I N ~(n o . ~ 42: 3) . ~ O n e ~ o t h e r ~ g r a i n, ~}$ emmer ( $\bar{A}$ Š.AN), is mentioned just once in our texts (no. 47:2) as is also flour made of a legume called GÜG (no. 48:5). 
Next to barley, the most commonly mentioned provision is oil of different kinds, as oil, without any descriptive adjective (IA, passim), thin oil (IÀ.SIG.A, no. 38:6), and sesame oil (IÀ.'GIS广', no. 47:1). The fact that sweet butter is mentioned only once (IÀ.NUN.DƯG, no. 34:5) indicates that milk and its products played a relatively small role in the life of the people. That the ancients knew beer is shown by the occurrences of KAŠ (no. $46: 1$ ?, 5 ?) and NINDA.BAPPIR (no. 33:1, 18, 54), the well-known ingredient in beer-making. Such secondary products as straw (IN.U, no. 37:17) and reeds (GI, nos. $23: 7 ; 41: 5$ ) are also mentioned. Salt as condiment is found perhaps in no. 44:16.

Many varieties of trees occur in the texts, such as tamarisk, myrtle, and laurel, to mention only the ones which can be translated with any degree of certainty. A great number of them appear in texts nos. 33 and 39 , particularly.

Of the domestic animals, sheep and goats were most common (nos. 32:1; 34:1; 37:1, and 5). Oxen (GUD, no. 37:3) and calves (AMAR, nos. 38:4; 41:13) occur rarely. Also, swine are found in nos. $16: 2 ; 37: 6 ; 38: 3$, although the interpretation of DUN is not quite sure. The existence of dogs is attested by the personal name Kalbum (no. 29:1), and of mice by Hulium (no. 1:5). Equids are represented by two terms which still remain obscure (ANŠE.BAR. AN, no. 31:1, and ANŠE.LIBIR.SAL, no. 21:4).

Silver (KUG.BABBAR) is the most frequently mentioned metal, which is only natural in view of the fact that silver was money in ancient times. Copper (URUDU, nos. $7: 1 ; 39: 4 ; 45: 5$ ), bronze (UD.KA.BAR, nos. 7:2; 16:8), and gold (KUG.GI, nos. 33:61; 44:8) are also mentioned. The standard measure of weight is the "stone of silver" ( $\mathrm{NA}_{4}$ KUG.BABBAR, no. 36:19).

A great number of garments are named in nos. 4, 7, 34, 35, 37, 38, but unfortunately English translations for the names of the individual pieces of apparel cannot yet be given. Wool (SÍG) for cloth is mentioned several times (nos. $34: 6$ ?, 9?; 36:18, 26). Carded wool (GIŠ.NI, no. 47:13) and an unknown kind of material called kutnum (no. 11:13) occur also.

Many tools and implements pertaining to all walks of daily life appear in the texts. Plows were certainly used in this period, although their occurrence in our texts is questionable (GIS.APIN in no. 38:7). Reference is made to another agricultural implement in a text which mentions the "teeth" or pegs attached to threshing boards (šinnāt kišzappī, no. 33:17, 31,36). Parts of chariots (na- 
ba-tum, no. 33:13) and wagons (GIŠ.KA DUBBIN, ibid. line 34) point to the use of these vehicles. Among wooden implements we know of pegs (GIŠ.K[A], no. 33:6), hoes (allum, ibid. line 16), spades (GIŠ.MAR, ibid. lines 7, 53), boards (GIŠ.DA, ibid. line 8), trays (GIŠ. $\mathrm{KID}_{5}$, ibid. lines 9 , 33, 39i:), poles (tirkullum, ibid. line 22), staffs (GIŠ.GÍD, no. 34:8), distaffs (GIŠ.ZUM + TÚG, no. 7:20), and baskets (sussulum, ibid. line 19).

We know of leather made of the skins of goats (KUŠ MÁŠ, no. 34:1), oxen (KUŠ GUD, no. 37:3), and pigs (KUŠ DUN, no. 38:3). Out of leather were made sandals (KUŚ.ŠUHUB, no. 44:5), sacks (KUŠ.(LAL.)A.GÁ, nos. 33:41; 34:7; 48:3, 6), skin buckets (mašlium, no. 7:10), and water skins (EDIN.A.SU, nos. 7:11 and 34:4). An object of leather was the dabašinnum (no. 7:14). The function and material of certain other receptacles, such as AN.ZA.MU (no. 34:3), ŠAKAN (ibid. line 5), madla um (no. 37:8), hupšašûm (no. 41:7), nama um (no. 43:3), kapturrum (ibid. line 4), and GUR (nos. $41: 4 ; 43: 14$ ) have not yet been ascertained.

Finally, there are the doubtful occurrences of a drum for musicians (tiggûm, no. 41:14) and of a mirror (mašălum, no. 7:1), which may attest to the gayer side of life. The occurrence of wicks (bușinnum, no. 41:6) proves the existence of oil lamps for purposes of illumination.

\section{TABLES OF MEASURES}

For the sake of convenience the following sets of equivalents, taken from Thureau-Dangin, "Numération et métrologie sumériennes," $R A$ XVIII (1921) 123-42, are offered. It is to be noted that the tables contain only those measures which are found in our texts.

\section{Linear Measures}

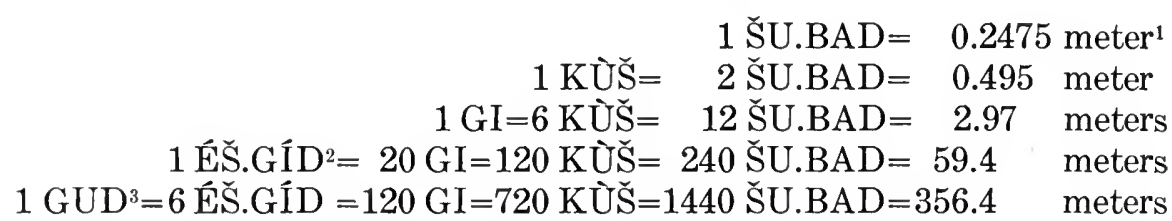

${ }^{1}$ One meter $=1.0936$ yards.

${ }^{2}$ Provided ÉŠ.GíD corresponds to ÉŠ in Thureau-Dangin's tables. See n. to no. 25:1.

${ }^{3}$ Provided GUD corresponds to UŠ in Thureau-Dangin's tables. See n. to no. $26: 1$. 
2. Surface Measures

$1 \mathrm{SAR}=35.2836$ square meters ${ }^{1}$

$1 \mathrm{GA} A=100 \mathrm{SAR}=3528.36$ square meters

$1 \mathrm{BUR}=18 \mathrm{GA} \mathrm{N}=1800 \mathrm{SAR}=63510.48$ square meters

3. Measures of Capacity

$1 \mathrm{QA}=0.842$ liter $^{2}$

$1 \mathrm{PI}=60 \mathrm{QA}=50.52$ liters

$1 \mathrm{GUR}=5 \mathrm{PI}=300 \mathrm{QA}=252.6 \quad$ liters

4. Measures of Weight

1 GÍN $=0.0084167$ kilogram $^{3}$

$1 \mathrm{MA} . \mathrm{NA}=60 \mathrm{GÍN}=0.505 \quad$ kilogram

$1 \mathrm{GU}=60$ MA.NA $=3600 \mathrm{GIIN}=30.3 \quad$ kilograms

${ }^{1}$ One square meter $=1.196$ square yards.

${ }^{2}$ One liter $=1.0567$ quarts.

${ }^{3}$ One kilogram $=2.2046$ pounds. 


\section{Transliterations, Translations, and Notes}

\section{1 (FM 229237)}

A very well-preserved tablet recording the measuring of a house by Mututu for Ilum-asû. The measuring was witnessed by eight men, whose names are listed at the top of the document. On the problem of measuring see the note to line 12 .

\section{Transliteration and Translation}

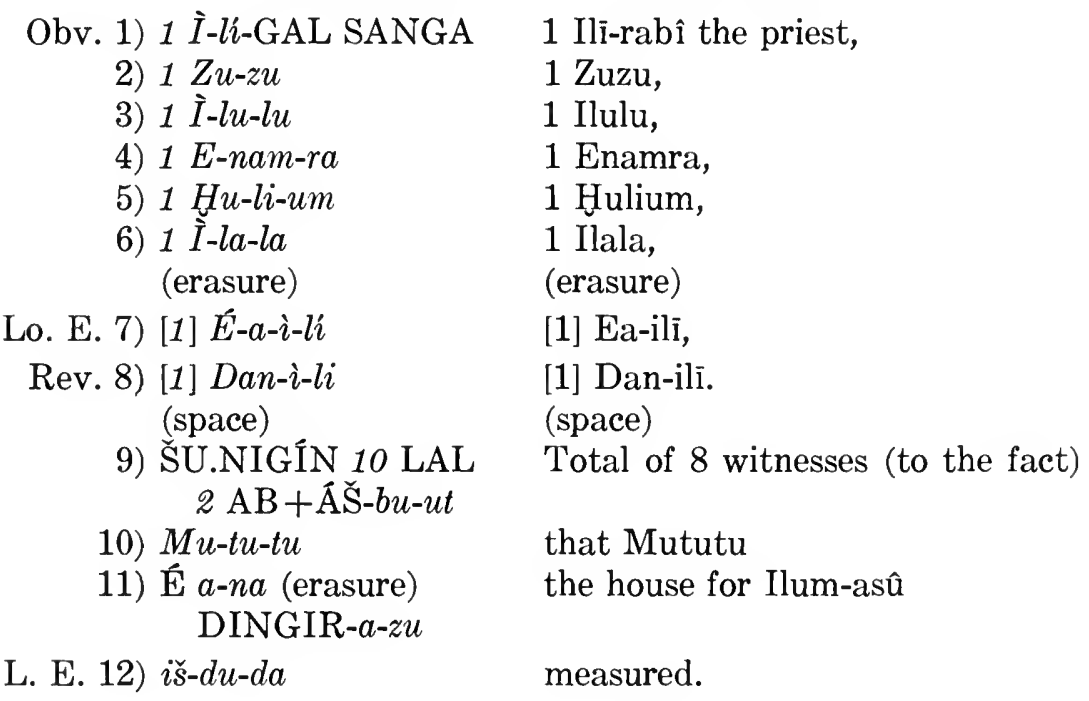

\section{Notes}

Line 3.- The reading of NI.LU.LU as $I-l u-l u$ is based on comparison with $I-l u_{5}-l u_{5}$ in Meek, HSS X 153 vi 15 . On the use of the sign LUL with the value $l u_{5}$ see also the remarks by the author in $A J S L$ LIII (1936/37) 38 top. In conformity with the reading of NI.LU.LU as $\bar{I}-l u-l u$, the name NI.LA.LA in line 6 is read as I-la-la. Cf. also the remarks on the reading of Izaza under no. 30:4. 


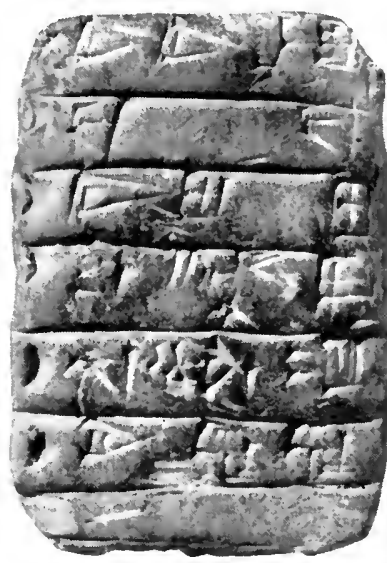

Obverse

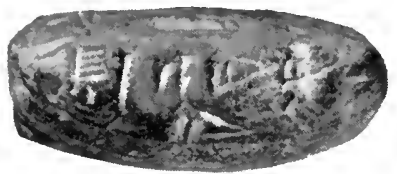

Lower Edge

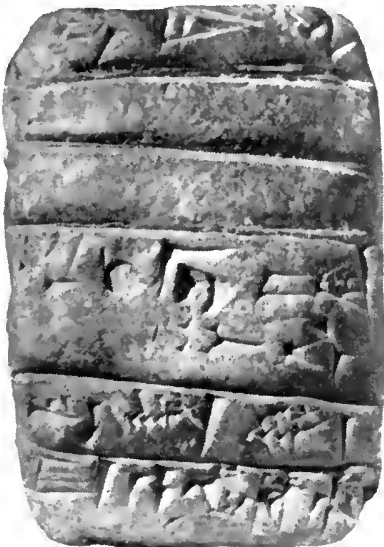

Reverse

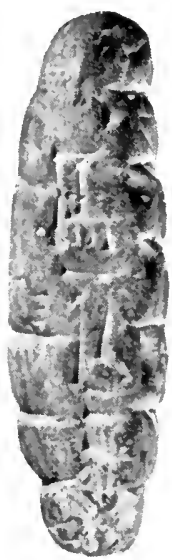

Left Edge

Line 9.- It has long been conjectured that the logogram $\mathrm{AB}+\mathrm{A} \check{\mathrm{S}}$ means "witness" and that its corresponding Akkadian form is šîbum. Cf., for example, among the older references B. Hrozný in WZKM XXI (1907) 25ff. and XXIII (1909) 193ff. and more recently Koschaker in OLZ XXXIX (1936) 151 and in $Z A$ XLIII

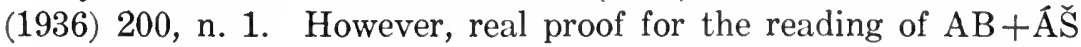
was lacking prior to the discovery in our collection of several occurrences of this logogram with the phonetic indicators -bu-ut (nos. $1: 9 ; 4: 14 ; 6: 7$ ), -bu-tum (no. 9:12), and -bu-zu (no. 14:11).

The Akkadian word šîbum means "gray," "old," "old man," or "elder" (of village or city). The meaning "witness" developed 
evidently from the fact that it was usually the older men or elders who served as witnesses to legal transactions. The distinction between "elder of the city" and "witness" is normally expressed in our texts by the writing $\mathrm{AB}+\overline{\mathrm{A}} \breve{S}$ URU $\mathrm{U}^{\mathrm{KI}}$ for the former and $\mathrm{AB}+\overline{\mathrm{A}} \breve{\mathrm{S}}$ alone for the latter.

The construction šîbūt Mututu . . . išduda, "witnesses (to the fact) that Mututu ... measured," is correct from the standpoint of Akkadian grammar. Cf. the parallel contruction awât iqb $\hat{u}$, "the word he said," cited in A. Ungnad, Babylonisch-assyrische Grammatik (2nd ed.; München, 1926) §16a. The other possible construction,

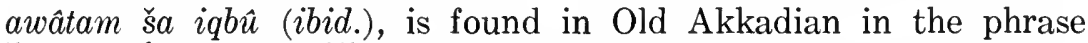
ŠU.NIGÍN $5 \mathrm{AB}+\mathrm{A} \breve{S}-b u$-tum šu-ut en-ma Be-lí-sa-tu a-na Gi-nu-nu, "total of 5 witnesses (to the fact) that thus (said) Bêlī-šadû to Ginunu" (no. 9:12-15).

Line 10.-Mu-tu-tu as a personal name appears also in Meek, $H S S \mathrm{X} 154 \mathrm{v} 15$. The name can be interpreted as Mututu, a partially reduplicated form of the class discussed below (p. 325).

Line 11.- There is a trace of an erased sign in front of DINGIR.

Line 12.--The primary meaning of šada $d u m$ is "to pull," "to drag." Its secondary meaning, "to measure," seems to have developed from the use of this verb to denote the pulling of a cord for the purpose of measuring fields and buildings. Perhaps the clearest example of šadadum, "to measure," is found in an Old Babylonian letter translated by Ungnad, $B B$ no. 135 , which gives measurements of the dirt excavated in the digging of a certain canal.

In the Old Babylonian period this verb is frequently found in the well-known phrase $\hat{u} m$ ebūrim eqlam ana pî šulpišu (var. šulpišunu) išaddadīma, but its translation is an old crux interpretum. However, today most scholars seem to follow B. Landsberger in his translation of šadādum in these clauses as "to measure" (WZKM XXVI [1912] 127-30); cf. A. Walther, Das altbabylonische Gerichtswesen ("Leipziger Semitistische Studien" VI 4-6 [Leipzig, 1917]) pp. 201f.; Koschaker and Ungnad, Hammurabi's Gesetz VI 108ff. For other opinions see B. Meissner, Beiträge zum altbabylonischen Privatrecht (Leipzig, 1893) p. 141 ("zurückgeben"); M. Schorr, Urkunden des altbabylonischen Zivil- und Prozessrechts (Leipzig, $1913)$ pp. 177f. and 551 ("eggen" or "abernten"); W. Schwenzner, MVAG XIX 3 (1915) pp. 82ff. ("aufrechnen"). Further literature is cited in all these references. Cf. also Landsberger in Journal of Near Eastern Studies VIII (1949) 280, n. 106. 
Use of the verb šadadum is rare in the Old Akkadian period. Outside of our text we find it in nos. 2:4 ("A $i \check{s}-d u-u d$ for B logs for a house") and 8:21 ("A $i s ̌-d u-u d$ for B a 'chair-house' for the price of barley"). Outside of our collection only one Old Akkadian tablet ( $M A D$ I 336), referred to below in the discussion on no. 8:18, uses this verb (" 4 men $i s ̌-d u$-tu for B 4 'chair-houses' "). The structure of the Old Akkadian texts which employ the verb šadādum is rather simple. A man (or men) measure(s) a certain building (or logs for a building) for a certain person; in all cases a number of witnesses are present.

That these texts cannot be explained simply as documents testifying to the act of measuring the buildings is evident from our no. 8 , in which a certain person "measures" for another person a house for the price of barley. It seems hardly likely that one would pay for services rendered in measuring a house. On the other hand, neither can an outright sale be concerned, since sale documents have a different phraseology, best exemplified in our no. 4: "A gave to B so much silver as the price of an object." It seems plausible therefore, to assume that our tablets represent the intermediate stage between "measuring" and "selling," that is, they are documents testifying to the fact that A measured a certain building with the intention of selling it to B. It is possible that another real sale contract was drawn up at a later time. But it is also possible that the contract mentioning the measuring sufficed for the purpose. The verb šadādum could then be interpreted as "to measure with the intention of selling" or as "to measure off." The semantic development of šadādum, "to measure," "to measure off," used with reference to the linear measurement of buildings or fields would be parallel to the development of the meaning of madādum, "to measure," "to measure out," used with reference to measures of capacity, as in the case of grain or flour. A similar semantic development can be observed in šaqălum, "to weigh," and also "to weigh out" ("to pay"), used with reference to metals. At a later time the verb šadādum is used with reference to providing a man (amèla išaddad) for another man, as in the Nuzi text translated by $\mathrm{H}$. Lewy in Orientalia, n. s. X (1941) 329f.

The emphasis placed upon "measuring" in the transfer of property finds its natural explanation in the fact that a sale could be contested at a later time if the property bought proved to be smaller than had been agreed upon. Cf. M. San Nicolò, Die Schlussklauseln der altbabylonischen Kauf- und Tauschverträge (München, 1922) pp. 206f. To protect himself against such an eventuality the 
seller drew up a memorandum naming the men who witnessed the measuring of the property before the actual sale. In the case of future litigation he could call upon them to testify in his behalf. The importance of measuring property is attested by the existence of official surveyors called LÚ.ÉŠ.GÍD in the time of Maništušu (see Scheil, Mém. II 29 and 31) and Urukagina (see Thureau-Dangin, Die sumerischen und akkadischen Königsinschriften [Leipzig, 1907] p. 48 iv 2), discussed by Hrozný in WZKM XXV (1911) 319.

The form in $-a$, found in $i \breve{s}-d u-d a$ of our tablet, occurs in the following texts of our collection:

1) ŠU.NIGÍN 10 LAL $2 \mathrm{AB}+\mathrm{A} \breve{S}-b u-u t M u$-tu-tu É $a$-na DINGIR- $a-z u$ iš- $d u-d a$, "total of 8 witnesses (to the fact) that Mututu measured the house for Ilum-asû" (no. 1:9-12).

2) $\mathrm{AB}+\overline{\mathrm{A}} \breve{\mathrm{S}} 1$ (PI) $\check{\mathrm{SE}}$ Gi-nu-nu a-na Dar-e-tum i-ti-na, "witnesses (to the fact) that Ginunu gave 1 PI of barley to Dar'etum" (no. 3:7-10).

3) in É ši uš-da-a-bi-la, "in the house, in which I had reconsidered (the matter)" (no. 10:8).

4) $\check{u} u$ a-na $\breve{S} u$-ni-tum $a$-ti-na, "that which I gave to Šunitum" (no. 21:5ff.).

5) ŠE.HAR.AN $\grave{E}$-ni-um šu Na-bi-um in i-te-su $i k$-su $u_{4}-r a$, "the HAR.AN-barley of Enium which Nabium with his... ...-ed" (no. 36:6-9). Cf. also $i k-s u-r a$ in a broken context in no. 14:30.

Most of the examples cited above occur in clear context and lead to the unescapable conclusion that the forms in - $a$ represent the subjunctive. Now, of all the Semitic languages only Arabic has a subjunctive in - $a$; in Akkadian, as is generally known, the subjunctive ends in $-u$.

Besides the subjunctive in $-a$ the tablets in this collection use also the normal subjunctive in $-u$, as in $e-m u-r u$ (plur., no. 6:10), $i t$-ba-lu (no. 7:24), [á]š-tu-ru (no. 53:5). It is important to note that no examples of the subjunctive in $-a$ can be found in any other Old Akkadian texts outside of our collection. Evidently this is a characteristic not of the Old Akkadian period in general, but solely of the region in which our collection originated. The occurrence of the subjunctive in $-u$ in the texts of this collection may have to be explained as being due to an outside dialectal influence. 


\section{2 (FM 229227)}

The contents of this text are simple. Six men, identified by their professions or genealogies, are witnesses that Îdâ-pi-ilì measured for Bêlì-bānî certain logs for a house.

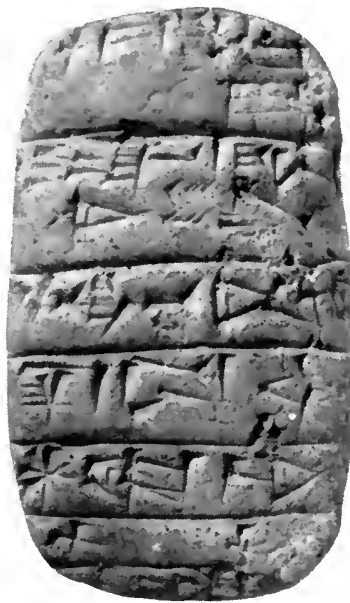

Obverse

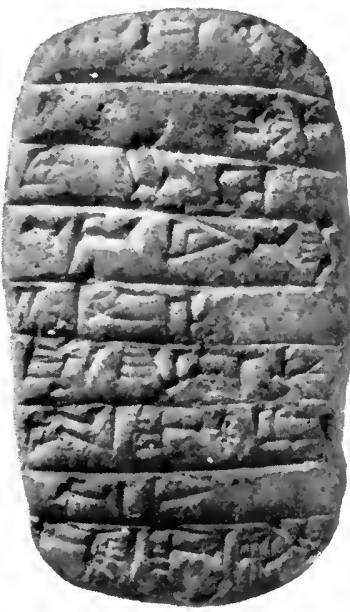

Reverse

TABLET 2 (FM 229227)

Transliteration and Translation

Obv. 1) $1 \frac{1}{2}$ GIŠ.IŠ.DÈ É

2) $I-d a-b i-i-l i$

3) $a-n a B e-l i-b a-n i$

4) $i \check{s}-d u-u d$

5) ${ }^{\mathrm{d}} \mathrm{KA}-\mathrm{Me}$-ir

6) MAŠ.MA

7) $I$-nin-'núm

Rev. 8) A-bí-bí

9) $2 X$

10) $K u-r u-b a$

11) Ti-ni-na

12) 2 DUMU- $a$

13) Ra-bi-DINGIR

14) $\operatorname{Im}_{\mathrm{x}}(\mathrm{DU})-d a-l i k$

15) MƯ̌EN.DÜ

16) $\mathrm{AB}+\overline{\mathrm{A}} \mathrm{S} D a-b i$-lum
$11 / 2$ IŠ.DE-logs of the house Îdâ-pi-ili for Bêlī-bānî measured. $\mathrm{Pu}-\mathrm{Mer}$ the incantation priest, Ininnum, Abibi, $2 \ldots$, Kuruba, Tinina, 2 sons of Rabî-ilum, Imtalik the fowler. Witnesses of Dabilum. 


\section{NoTES}

Line 1.-GIŠ.IŠ.DE occurs in some Ur III texts, as in De Genouillac, ITT II 4508:1, 4, 6 and 4646 rev. 4f. Cf. also 1 GIŠ.IŠ.DE GIŠ.HAS̆HUR, "1 IŠ.DÈ-log of an apple tree," in De Genouillac, ITT V 9273:3, which shows that GIŚ.IŠ.DE are not trees but presumably logs for a building. 1 GIŠ.IŠ.DE occurs perhaps in no. 4:2. For an additional Old Akkadian example cf. n. to no. 36:5.

Line 2.- The name $I-d a$-BÍ-NI-li can be interpreted either as Îdâ-pi-ilī, "he knows the word of my god," or as Îdā-pi-ilì, "obey the word of my god!" The Old Akkadian genitive form is $i l \bar{\imath}$, not ilija, as can be seen from many examples, best of which is $[a]-n a$ $S i$-HUR.SAG be-lí $\grave{u} a$-bi, "to $\breve{S}$. my lord and my father," in $M A D$ I 191:4f.

Line 5.-The personal name ${ }^{\mathrm{d}} \mathrm{KA}-\mathrm{Me}$-ir occurs also in Scheil, Mém. II pl, 4 v 3, Scheil and Legrain, Mém. XIV 6 ii 1, Meek, $H S S \times 13$ ii 9, and as KA-Me-ir below in no. 9:4 and MAD I 162:4. The interpretation as -ka-me-ir from kamārum by Ungnad in $M V A G$ $\mathrm{XX} 2$, pp. 58f. is impossible since the $\mathrm{KA}$ sign does not have a syllabic value $k a$ in Old Akkadian.

Line 7.- The name $I-n i n-{ }^{-} n m^{1}$ is reconstructed on the basis of I-nin-núm in MAD I 163 viii. Cf. also I-nin-um in Scheil and Legrain, Mém. XIV 10 rev. ii $\mathrm{x}+9$ and 72 iii 8 .

Line 9.-The unread sign in this line is a perplexing one. It should represent the profession of the two men mentioned in lines 7 and 8.

Line 12.-The form DUMU-a Ra-bi-DINGIR, referring to the names in lines 10 and 11, is probably to be read as mar'a Rabî-ilum, construct state of the dual mar'ān from marsum, "son." On the latter form see Gelb, OIP XXVII pp. 21ff.

Line 14.- The name DU-DA-UR occurs frequently in Old Akkadian texts, for example, in Scheil, Mém. II p. 43, Scheil and Legrain, Mém. XIV p. 127, Meek, HSS X p. xxx. On the reading $I m_{\mathrm{x}}-d a-l i k$ cf. $M A D$ II under the sign DU.

Line 16.-The form Da-bi-lum in line 16 is most probably a short form for $I-d a-b i-i-l i$. 


\section{3 (FM 229230)}

Four men are witnesses that Ginunu gave (sold) a certain amount of barley to Dar'etum.

\section{Transliteration and Translation}

Obv. 1) $E$-gi

2) $\check{u} T a b$-si-ga

3) $E \check{s}_{4}$-dar-sa-tu

4) ARĀD- ${ }^{\mathrm{d}}$ Innin

5) $M a$-šum

6) DUMU Maš-tum

Rev. (space)

7) $\mathrm{AB}+\overline{\mathrm{A}} \check{\mathrm{S}} 1$ (PI) $\check{\mathrm{S}} \mathrm{E}$

8) $G i-n u-n u$

9) a-na Dar-e-tum

10) $i$-ti-na

11) GEMÉ $I b-b u-b u$

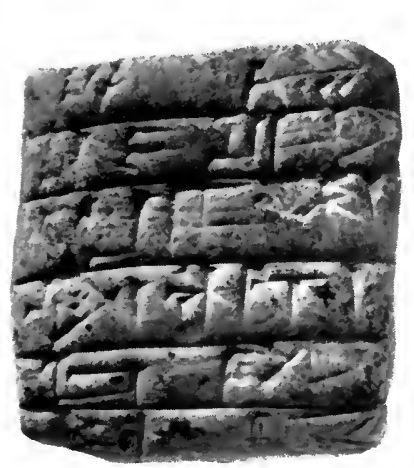

Obverse

Obverse
Egi

of Tabšiga,

Eštar-šadû,

Warad-Innin,

Mašum

son of Mašdum.

(space)

Witnesses (to the fact) that $1 \mathrm{PI}$ of barley

Ginunu

to Dar'etum

gave.

Slave girl of Ibbubu.

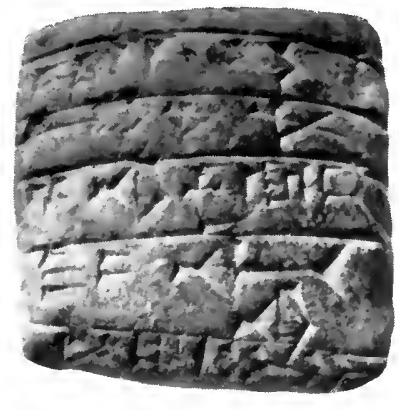

Reverse

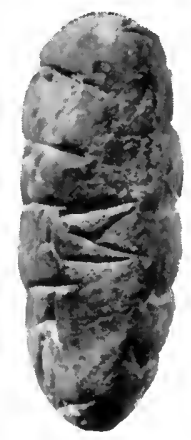

TABLET 3 (FM 229230)

\section{Notes}

Line 1.-The expression šu "he (of somebody)" does not stand for paternal relationship, as has been suggested some years ago, but denotes a clan affiliation. See $n$. on page 324 . In the following such expressions are translated as "of."

Line 2.-The personal name Tab-si-ga sounds very much like $D u b-s i-g a$, found frequently in the Old Akkadian inscriptions 
(Meek, HSS X p. xxx; Scheil, Mém. II p. 43; CT XXII 7 R.E. 12; etc.); in the later period this name is found in the form Tupšikka at Nuzi; see Gelb, Purves, and MacRae, OIP LVII 159. On the interchange of TAB and DUB cf. for example, ${ }^{\mathrm{d}} A k-d u b$-bi-tum and $\bar{A} k-t a b^{\mathrm{KI}}$ in an inscription published by A. Poebel in Journal of the American Oriental Society LVII (1937) 367:1. On the - $a$ ending see below, under no. 25:2.

Line 3.-My reading of the name of the famous Mesopotamian goddess as Eštar, not Ištar, is based on the one hand on the fact that I do not know of any spelling of this name with the IŠ sign for the early periods. On the other hand, in favor of the reading es may be cited not only the old traditional spelling $E \check{S}_{4}-d a r$, but also $\breve{S} u$-Eš-dar (CT V 46b 20; Thureau-Dangin, RTC 355:5; G. Reisner, Tempelurkunden aus Telloh [Berlin, 1901] p. 51 [under $\check{S} u$-ěs-sí(dar)]), Puzur-Ěs-dar (CT V 46:3; Reisner, op. cit. p. 50 [under Sú-ša-ěs-sí (dar)]), etc.

Line 11.-The line containing the words "slave girl of Ibbubu" is poorly connected with the rest of the inscription. Evidently, the scribe, having forgotten to write these words in the correct place, was forced to add them at the end of the inscription. Probably they belong after the personal name Dar-e-tum, which is found among fem. names in the Old Akkadian tablet $M A D$ I $7 \mathrm{x}+\mathrm{i}$.

The personal name $I b-b u-b u$ is found also in Scheil, Mém. II pl. 9 vi 1; Thureau-Dangin, ITT I 1350:6; Meek, HSS X 108:14. 


\section{4 (FM 229205)}

Sale of lumber by Pu-Tišpak to Ilum-dan. Five men witnessed the transaction.

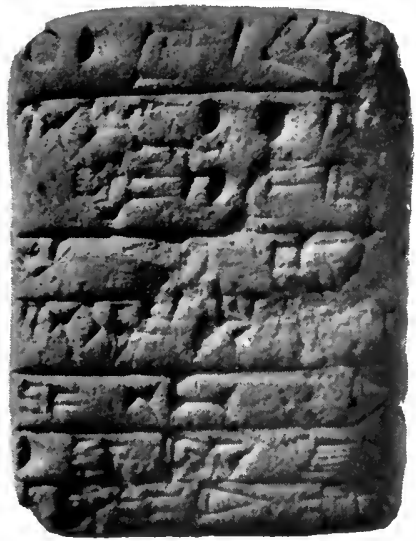

Obverse

TABLET 4 (FM 229205)

Transliteration and Translation

Obv. 1) 11 GÍN KUG.BABBAR 11 shekels of silver,

2) $a$-na ŠÁM 1 GIŠ.IŠ.DE for the price of 1 IŠ.DÈ-log at 1 GÍN ...

3) DINGIR-dan

1 shekel of ....

4) $a-n a P \grave{u}$ - $\mathrm{T}$ Tišpak Ilum-dan

5) $i$-ti-in to $\mathrm{Pu}-T i s ̌ p a k$

6) 1 I-gu-núm gave.

1 Ikûnum

7) 'DUMU' I-ni-um 'son' of Inium, 

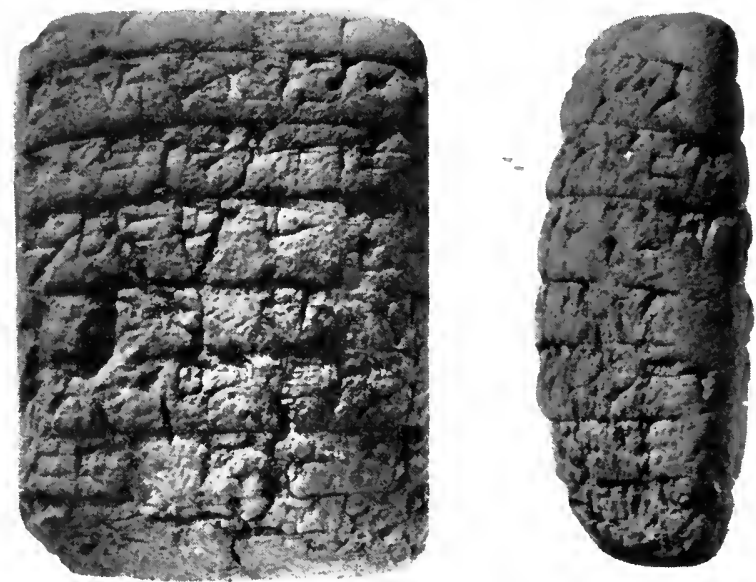

Reverse

TABLET 4 (FM 229205)

Rev. 8) $1 \check{S} u$-BÀD

9) DUMU Ši-ir-e-si-na

10) $1 P \grave{u}-{ }^{\mathrm{d}} T i s ̌ s p a k$ UGULA URU

11) NU.BANDA $\grave{I}-l i-i \check{s}-$ $d a-g a[l]$

12) 1 'ARÁD'-Tu-tu

13) DUMU Be-li-GUR ${ }_{7}$

14) $\mathrm{AB}+\overline{\mathrm{A}} \check{\mathrm{S}}-b u-u t$

15) ' $\mathrm{gu}$ '-su-ra-im
1 Šu-dûrī son of Šrirešina, $1 \mathrm{Pu}$-Tišpak the .... ,

the administrator Iliš-takal,

1 'Warad'-Tutu son of Bêlī-GUR ${ }_{7}$.

Witnesses

of the transaction.

\section{NOTES}

Line 2.-For the discussion of GIŠ.IŠ.DÈ cf. no. 2:1.

Line 15. -With $\mathrm{AB}+\overline{\mathrm{A}} \check{\mathrm{S}}-b u-u t$ ' $g u^{\prime}$-su-ra-im of our text cf. $\mathrm{AB}+\overline{\mathrm{A}} \breve{\mathrm{S}} . \mathrm{AB}+\mathrm{A} \check{\mathrm{S}} g u$-su $u_{4}$-ra-im (Louvre $\mathrm{AO} 8638$ end) and $\mathrm{AB}+$ ÁŠ-bu-ut gu-su[r-r]a-i[m] (MAD I 179 end). The noun $g / k u s ̌ u r r \bar{a} \bar{a}^{3} u m$ may mean "contract" or "transaction," possibly from the root G/KŠR "to reinforce." 


\section{5 (FM 229238)}

The tablet is rather difficult to interpret owing mainly to my inability to read line 13. In lines 1-3 it is stated that a person named Mașșāršu has received (borrowed) 4 shekels of silver. Then-if my interpretation is correct--seven witnesses are named who saw that, presumably in the house of somebody named in line 13 , henamely, Mașsāršu - gave (returned) 2 shekels of silver to Igini. It is not sure that line 13 contained a personal name. Igini seems to be the person who lent money to Mașșāršu.

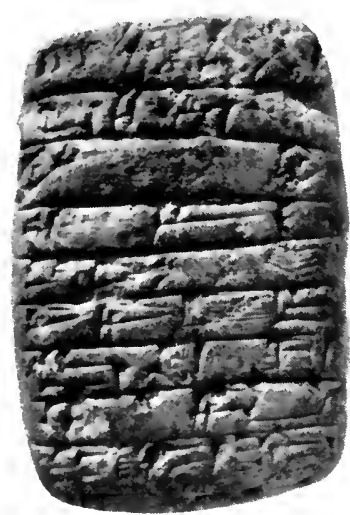

Obverse

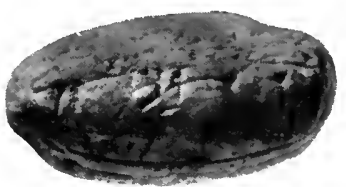

Lower Edge

TABLET 5 (FM 229238)

Transliteration and Translation

Obv. 1) 4 GÍN $1 / 3$ S̆A KUG. $41 / 3$ shekels of silver BABBAR

2) Ma-za-ar-su Mașșāršu

3) im-hur received.

4) DINGIR-dan Ilum-dan,

5) I-gu-núm Ikûnum,

6) İ-li-sa-liq Ilï-šaliq,

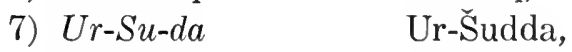

8) UD-kum UD-kum,

9) $I$-bi-bi Ibibi,

Lo. E. 10) $A-d a m-u \quad$ Adam’u. 


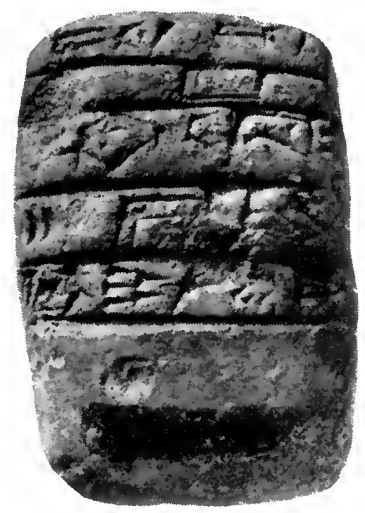

Reverse

TABLET 5 (FM 229238)

$\begin{array}{ll}\text { Rev. 11) } \mathrm{AB}+\overline{\mathrm{A}} \check{\mathrm{S}} . \mathrm{AB}+\overline{\mathrm{A}} \check{\mathrm{S}} & \text { Witnesses (to the fact) } \\ \text { 12) }[\mathrm{x}] \overline{\mathrm{E}} & \text { that (in) the house } \\ \text { 13) } \mathrm{X}-s u-d u-u m & \text { of } \ldots \text { šudum } \\ \text { 14) } 2 \mathrm{GÍN} \mathrm{BABBAR} . & 2 \text { shekels of silver } \\ \mathrm{KUG} & \\ \text { 15) } a-n a I-g i-n i & \text { to Igini (he returned). }\end{array}$

\section{Notes}

Line 1.-Underneath the sign GÍN there are traces of wedges which may best be interpreted as $1 / 3$ S A, that is, "one-third of a shekel."

Line 2.-Mașșārum means "security," "pledge," but this does not fit into the context.

Line 5.-The name $I$-gu-núm=Ikûnum, found in this tablet and also in nos. 4:6 and 53:2, occurs frequently in the tablets from Gasur. The reading I-gul-um and its interpretation as Ikûn-ilum in Meek, HSS X p. xxxii are not justified.

Line 6.-For occurrences of the personal name $I$-li-sa-liq see Ungnad, $M V A G \mathrm{XX} 2$ (1916) p. 74. Cf. also the spelling $\bar{I}-l i$-sa-li-iq in $C T$ VII 27, no. 18376 rev. 11.

Line 7.-The divine element Sudda, "the light of heaven," in the personal name $U r-S u-d a$ is very rare. It occurs in the personal 
name Puzur- $\breve{S} u$-da in an unpublished tablet of the Third Dynasty of Ur, Oriental Institute A 2980:8, and in several names of the Kassite period, such as ${ }^{\mathrm{d}} \breve{S} u-u d-d a-e-p i r^{i r}, \breve{S} u d-d a-k i-t u m,{ }^{\mathrm{d}} \breve{S} u-u d-d a-r i-$ man-ni, listed in A. T. Clay, PNCP p. 133. See also A. Deimel, Pantheon Babylonicum (Roma, 1914) nos. 2865, 2866, 2868, 2870, 3154 and Tallqvist, "Akkadische Götterepitheta," Studia Orientalia VII (1938) 449f.

Line 8.- The name UD-kum occurs also on several Old Akkadian tablets from Tell Asmar; cf. MAD I p. 224. Read perhaps Tamqum= Damqum?

Line 10.-The personal name $A$-dam- $u$ occurs also on three Old Akkadian texts listed in $M A D$ I p. 178. 


\section{6 (FM 229245)}

Six witnesses to a transaction in barley belonging to Nāṣir-ilī. The text offers some difficulties in line 8 , on which see later.

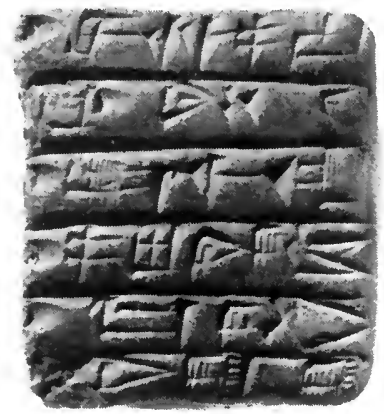

Obverse

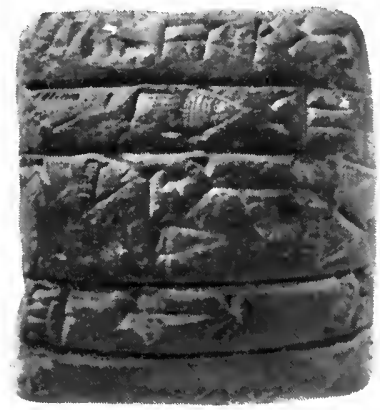

Reverse

TABLET 6 (FM 229245)

\section{Transliteration and Translation}

Obv. 1) 1 Da-lim UGULA URU

2) $\grave{u} 1$ GEMÉ-zu

3) 1 Ip-ti-um

4) 1 SIPA-i-tum

5) $1 M a$-šum

6) '1' $\grave{I}-l a-l a$

Rev. 7) ŠU.NIGÍN $6 \mathrm{AB}+\mathrm{A}$ Šbu-ut

8) ŠE.GA.KÚ

9) ŠE $\check{a} a N a-z i-i r-i-l i$

10) $e-m u-r u$
1 Talim the ....

and 1 Amassu,

1 Ipti'um,

1 Rēîtum,

1 Mašum

'1' Ilala.

Total of 6 witnesses

of the sale, the barley of Nāṣir-ilì examined.

\section{Notes}

Line 1.-Our personal name Da-lim corresponds to Talim(u), well known in the late period (Tallqvist, Neubabylonisches Namenbuch p. 211). On its meaning see Koschaker in ZA XLI (1933) 64-68; on the form see the discussion on no. 49:12.

The signs standing for the title UGULA URU are perfectly preserved both in our text and in no. 4:10. These two signs occur also in E. Burrows, Archaic Texts ("Ur Excavations Texts" II [London, 1935]) pl. XLVIII, no. 33 end, pl. L, no. 49 end, and-as 
Dr. Jacobsen points out-in E. Chiera, Selected Temple Accounts from Telloh, Yokha, and Drehem (no date) 10 passim, and L. Legrain, Business Documents of the Third Dynasty of Ur ("Ur Excavations Texts" III [London, 1937]) no. 1554 rev. ii passim, where they clearly stand for a word denoting the profession of a woman in charge of a group of women engaged in weaving. Jacobsen in Studia Orientalia Ioanni Pedersen dicata (Hauniae, 1953) p. 182 reads the two signs as PA GIŠGAL and compares Deimel, $\breve{S} L$ II 295:81.

Line 2.--Similar cases, such as $\check{S} u$-a-tum $\grave{u} D a-d a$ SAL, "Šuatum and Dada (his) wife," in no. 20, indicate that Amassu in our text is probably the wife of Talim.

Line 4.- The reading of PA.LU.NI-tum in this text as SIPA$i$-tum and of PA.LU!-tum in no. 10:3 as SIPA!-tum and comparison with Ri-i-tum in no. 30:10 was suggested to me by Dr. Jacobsen. It must be noted that a simple reading $P a-l u$-ni-tum ( $P a-l u$-li-tum) or Pa-ku-tum (Pa-lu!-tum) for these names is not permissible, because the sign PA does not have the syllabic value $p a$ in our texts. On the other hand, a name ${ }^{\mathrm{f}} \mathrm{R} i$-i-tum, "shepherdess," occurs in later texts (see Clay, PNCP p. 120).

Line 5.-- Our name $M a$-šum is evidently Mašum, "twin brother," found frequently in the Akkadian onomastic material. Cf. $M a-s ̌ u m$,

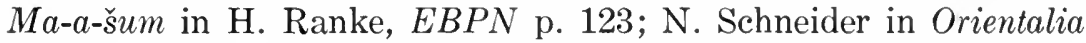
XXIII (1927) 161f.; VAS XVI 54:5; and the discussion in Gelb, Purves, and MacRae, OIP LVII 323.

Lines 7-10.-Comparison with ŠU.NIGÍN 10 LAL 2 AB + ÁS̆$b u-u t M u-t u-t u$ É $a-n a$ DINGIR- $a-z u$ iš- $d u-d a$, "total of 8 witnesses (to the fact) that Mututu measured the house for Ilum-asû" (no. 1:9-12), suggests that ŠU.NIGÍN $6 \mathrm{AB}+\mathrm{A} \breve{S}-b u$-ut ŠE.GA.KÚ ŠE ša Na-zi-ir-i-li e-mu-ru in this text should be translated as "total of 6 witnesses (to the fact) that Šegaku examined the barley of Nāṣir-ilì." However, since I can find no evidence for this personal name in cuneiform literature I prefer to interpret ŠE.GA.KU as an abstract noun with the meaning of something like "sale-transaction;" this meaning may be derived from an original expression še gaku, "may I eat the barley." Amärum with the meaning "to see" or "to examine (legally)" occurs also in MAD I 336 end and is frequent in later periods. 


\section{7 (FM 229246)}

In lines 1-20 the tablet lists various kinds of metal objects, garments, utensils, and provisions. In line 21 these items are designated as the movable property of Nabi'um, which Gišum had carried away. In respect to this property Nabi um swore in the gate of Tišpak that he stated the truth. The tablet ends with a list of witnesses for Gišum. This text resembles in appearance no. 36, both being written presumably by the same scribe.

\section{Transliteration and Translation}

Obv. 1) [1 ma-ša-lu]m URUDU [1 mirro]r of copper,

2) $[x$ G]Ú 1 MA.NA UD. [x ta]lents 1 mina of bronze, KA.BAR

3) 1 'TÚG'.GU.ZI.DA 1 large GU.ZI.DA-garment, GAL

4) 1 TÚG.A.SU GAL 1 large A.SU-garment,

5) 1 GI.NI.SÁ

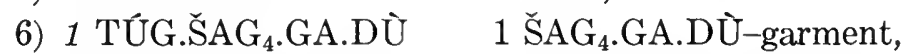

7) $6^{\mathrm{TUG}} b a r-r u \check{s} u$-ut SAG 6 coverings for the head,

8) 7 TÚG.BAR.SIG GAL 7 large BAR.SIG-garments,

9) 1 E.GI $\mathrm{GGI}_{4}$.DU.SU $1 \ldots$, É.BA

10) $3^{\mathrm{KUS}}$ maš-li-a-tum

3 skin buckets,

11) 4 EDIN.A.SU 4 water-skins,

12) $21 / 2$ QA IÀ

13) $20(\mathrm{QA}) \mathrm{ZIID}$. [̌SE]

14) $1^{\mathrm{KUS}} d a-b a-s i-n u m$ $21 / 2 \mathrm{QA}$ of oil, $20 \mathrm{QA}$ of [barley] flour. 1 dabašinnum, 

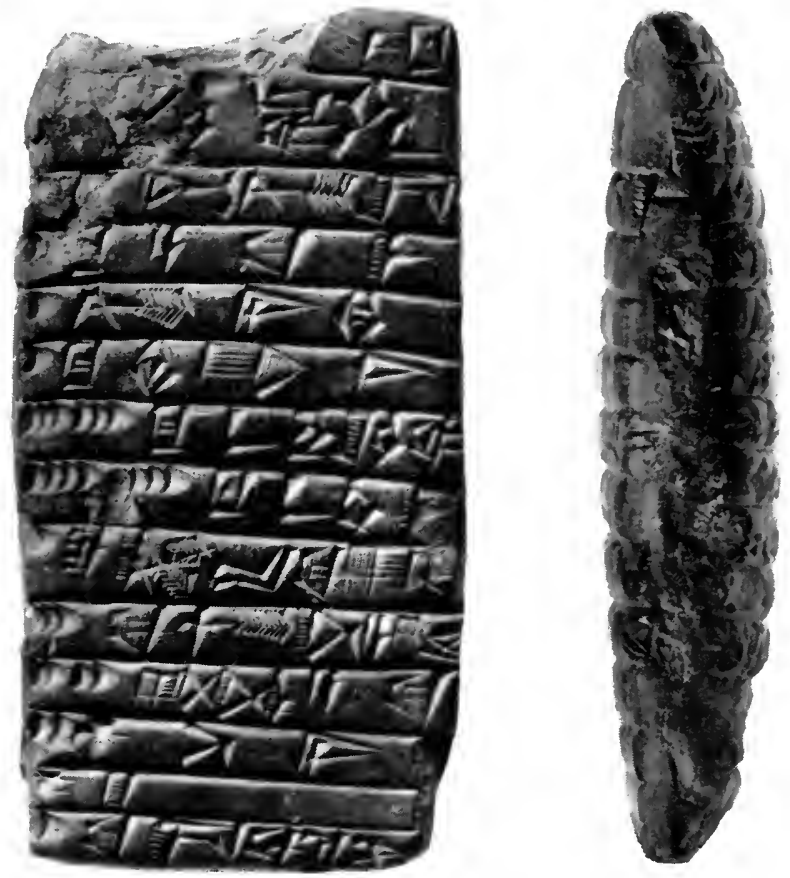

Obverse

TABLET 7 (FM 229246) 


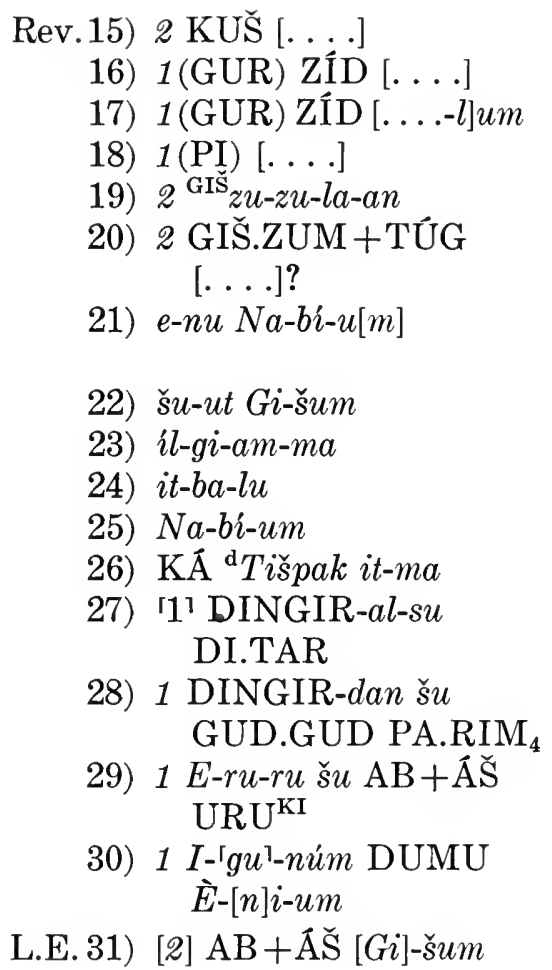

2 skins [....],

1 GUR of flour [....],

1 GUR of flour [....],

1 PI [....],

2 baskets,

2 distaffs.

(In respect to) the utensils of Nabi’um which Gišum took and carried away, Nabi'um in the gate of Tišpak swore. 11' Ilum-alšu the judge.

\section{Ilum-dan Of GUD.GUD the} bailiff.

1 Eruru Of the elder of the city,

1 Ikûnum son of Enium.

[2] witnesses of [Gi]šum.

\section{NoTES}

Line 1.-The only visible traces of signs in this line are those of the end of the sign LUM and the URUDU sign. The reconstruction to 11 ma-ša-lu]m URUDU is based on the frequent occurrence of $m a$-ša-lum UD.KA.BAR in texts of the Third Dynasty of Ur. For the references see Deimel, $\breve{S} L$ II 342:109. The occurrence of 1 $m a-s ̌ a-l u m$ UD.KA.BAR in the Old Akkadian period (Luckenbill, OIP XIV 100:1 and elsewhere) is very important because its spelling with $\breve{s}$ shows that the corresponding Arabic sibilant is $\underline{t}$, as in Arabic matala. In antiquity, mirrors were normally made of UD.KA.BAR "bronze"; I do not know whether they were made also of copper, if this is the exact translation for URUDU.

Line 3.-With 1 TUG.GU.ZI.DA GAL, "1 large GU.ZI.DAgarment," in our line ef. TÚG.GU.ZI.DA. SÍG, "a woolen GU.ZI. DA-garment," in no. 34:6. GU.ZI.DA is most probably an artificial Sumerian logogram for the Akkadian kusitum-garment. Cf. such parallels as Sumerian TU.DI.DA (Scheil in RA XVII [1920] 211-14 


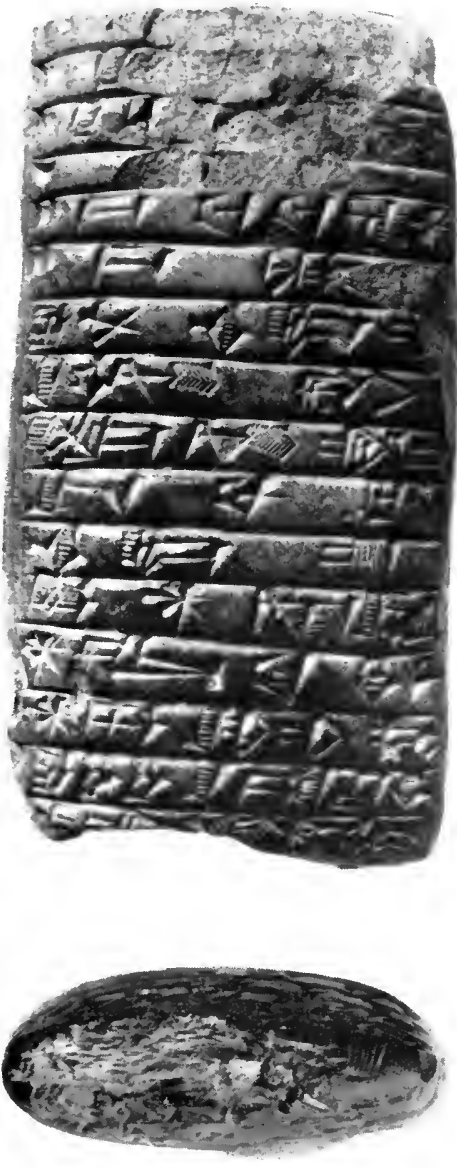

Reverse

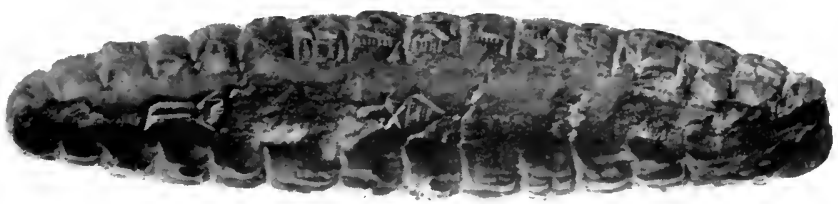

Left Edge

TABLET 7 (FM 229246) 
and passim), TU.TI.DA (Luckenbill, OIP XIV 105:7), and DU. TI.DA (in an unpublished Ur III tablet, Oriental Institute A 5834) =Akkadian dudittum, "pectoral," Sumerian AR.ZA.NA (Deimel, $\breve{S} L$ II 451:14)=Akkadian arsānum, some kind of flour, Sumerian DAM.HA.RA (Thureau-Dangin, SAKI p. 38 i 26)=Akkadian tamhārum, "battle," Sumerian MAŠ.GA.NA (Thureau-Dangin, op cit. p. 170 b iv 10)=Akkadian maškanum, "settlement," etc. All these artificial Sumerian logograms are loan words from Semitic, or, to be more exact, from a Semitic language which had not yet developed either the case ending or mimation (see also n. to no. 25:2). In favor of equating GU.ZI.DA with Akkadian kusitum, note also the occurrence of ....TUGG $g u$-zi-ti-[im] in no. 48:12f. and the comparison of TUGG.GU.ZI.DA SÍG in no. 34:6 with kusitum, made of wool, in the late Babylonian text published in J. N. Strassmaier, Inschriften von Cyrus, König von Babylon (Leipzig, 1890) 7:7, 10, 13.

The exact translation of kusîtum is not sure. It certainly represents a garment, especially a woman's garment. Often it is translated as "turban" but without much convincing evidence. Cf. Delitzsch, $A H W B$ pp. 342f.; C. Bezold, Babylonisch-assyrisches Glossar (Heidelberg, 1926) p. 145; H. Zimmern, Akkadische Fremdwörter als Beweis für babylonischen Kultureinfluss (Leipzig, 1915) p. 36; Deimel, $\breve{S} L$ III 2 p. 212 (where also various logograms for kusîtum are noted).

Line 5.-The logogram GI.NI.SA is not understandable to me, but it is clear from the context that it should denote some kind of garment. GI.NI of the Pre-Sargonic documents, cited in Deimel, $\check{S} L$ II $85: 85$, is hardly comparable, because GI.NI there forms an ingredient used in making a special kind of oil. One possibility would be to separate GI.NI.SÁ into two words, and to take SÁ as Akkadian šalmum, "intact," "whole," "complete." This is the word found in the Old Akkadian phrase a-na ni-ki-im SÁ, "for the complete libation," in Meek, HSS X 5:22. Since the sign DI never has the value $d i$ in Old Akkadian, Meek's interpretation as $n i$-ki$i m$-di, op. cit. p. xix, is impossible. The remaining word, GI.NI, could possibly be identical with TÚG.NI, "NI-garment," in the Old Akkadian tablets published in MAD I 169:4 and 187:21; we should interpret perhaps TÚG.NI as a "wool NI-garment" in parallelism to GI.NI a "reed NI-garment."

Line \%. - The Akkadian bar-ru or pár-ru, nom. plur., is in agreement with $\check{s} u$-ut.

Line 8.- Spelled TÚG.BAR.SI, this word appears frequently in the texts; see Deimel, $\breve{S} L$ II $74: 243$. The spelling TÚG.BAR.SIG, 
as on our tablets, occurs, for example, in $C T$ XVIII 9:33f., referred to by Deimel, $\breve{S} L$ II $74: 367$. The corresponding Akkadian word is paršigum, spelled with $p$, not $b$, as shown by pa-ar-ši-gu in $C T$ XVIII 13, K 275:1; 19, K $4377 \mathrm{x}+12$, and elsewhere. In the Old Akkadian text from Elam this word appears several times in the form ba-ar-si-gu-um (Scheil, Mém. XXVIII 526).

The word paršigum (written TÚG.BAR.SIG) is equated with $s i$-in-du šá A.SU in CT XVIII 9:33f., referred to above. The word sindu or simdu from the root ȘMD, "to bind," means "band" or "bandage" (as used by physicians). The word paršigum has a similar meaning; sometimes it is used for "headband," perhaps "turban." For șimdum in Old Akkadian see no. 35:9.

Line 9.-With the spelling 1 E.GI $\mathrm{GGI}_{4}$.DU.SU E.BA in our text we may compare 1 E.GI ${ }_{4} \mathrm{xGI}_{4} \cdot \mathrm{SU}$ E.BA in an Old Akkadian text, $M A D$ I 169:4, in which this word appears likewise among garments. 1 E. $\mathrm{GI}_{4} \times \mathrm{XI}_{4}$. BA occurs also in Scheil and Legrain, Mém. XIV 7:9. The meaning of the word is unknown to me. É.BA may be compared with É.BA.AN of Deimel, $\breve{S} L$ II 324:6.

Line 10.-The word ${ }^{\mathrm{KUS}}$ maš-li-a-tum is fem. plur. of mašlium, which is frequently found in the texts. See Deimel, $\breve{S} L$ II 7:61 and

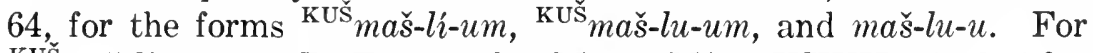

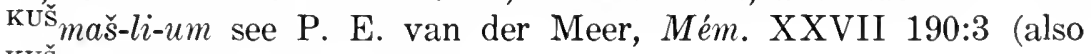
KUš maš-lí-um, ibid. no. 231:3).

The object called mašlium or mašl $\hat{u}$ is made of leather, as the determinative shows. It is equated with mašku, "leather," in a synonym list (see W. von Soden in $Z A$ XLIII 242:236). Since the word mašlium is a nomen instrumenti based on the root $\check{S}^{2}{ }_{7}$, "to dip," "to submerge," it is probable that the noun in question refers to an implement used for drawing water, such as a skin bucket.

Line 11.-For EDIN.A.SU see the discussion on no. 34:4.

Line 14.- In the same synonym list in which mašlu is equated with mašku, a word $d a-b a-s ̌ i-i n-n u$ is equated with šat-tu-u (line 235). Its meaning is unknown.

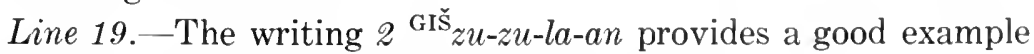
of the nom. dual of the noun sussulum, "basket."

Line 20.-For the form of the sign ZUM+TUGG see Deimel, $S L$ II 555:1. For some occurrences of this word in early texts see GIŠ.ZUM + LAGAB GIŠ.TÚG in A. de la Fuÿe, Documents présargoniques (Paris, 1909) 75 rev. ii 2, and Scheil and Legrain, Mém. XIV $7: 12$. For the translation as "distaff" see Deimel, $\breve{S} L$ II 555:1 and 11. 
Line 21.-The word $e-n u$, plur. in the construct state, seems to be the general term applied to all the objects and provisions enumerated in lines 1-20. I know of only one word which might possibly fit here. This is the word $e-n u-u m$, which occurs in a Cappadocian tablet published in Clay, BIN IV 24:11, in the phrase 1 ANŠE $s a-l a-m u-u m$ ù e-nu-um. Comparable also is 2 ANŠE șa-lá-me ù e-nu-sú-nu in S. Smith, Cuneiform Texts from Cappadocian Tablets in the British Museum II (London, 1924) 34:5f., and 1 ANŠE $\dot{u}$ $u$-nu-sú, ibid. IV (London, 1927) 42c 3f. and passim. In the Cappadocian tablets the variant forms enûm, enûtum, and unûtum mean not so much utensils as the trappings of a donkey. In other Akkadian texts unîtum normally means "utensils," "implements," "equipment," but sometimes the word is also used as a general term corresponding to our "movable property." This may be the required translation of $e-n u$ in our case. Also the occurrence of É.DÙ.A $m u$-ša-ab-ša qa-du e-na-ti-šu in Scheil, Mém. XXII 131:4f., where the enâtum of a residence clearly refer to its utensils or movable property, speaks in favor of the interpretation given above.

Comparable is perhaps also GIŠ $e$-ni Ù.URU.A in our text no. $33: 42$.

Line 22.-The personal name Gišum occurs also in Meek, HSS $\mathrm{X} 160$ i 7, Thureau-Dangin, ITT I 1471:2 and 1475:2, and MAD I pp. $198 \mathrm{f}$.

Line 26.-A similar oath appears in no. 51 rev. $\mathrm{x}+2 \mathrm{f}$.

Line $27 f$.- Judges and bailiffs as witnesses of an oath are attested also in MAD I 135 end and in an unpublished text at Oxford, numbered Kish 1930, 170d rev.

Line 28.-The personal name GUD.GUD could possibly be read as $G u_{4}-g u_{4}$ and compared with $G u-g u$ discussed under no. 33:47. Cf. also GUD.GUD=qarrādu in Deimel, $\breve{S} L$ II 297:64. 


\section{8 (FM 229254)}

In spite of its good state of preservation this tablet was difficult to interpret at first. Explanation of some of the difficulties involved is given in the discussion on line 18. However, it now seems to me that I can offer a reasonably good interpretation of the text. Six men, whose names, genealogies, and titles are given in lines 1-8, are witnesses to the fact that Ginunu sold to Dan-ilī, for a certain amount of barley, two persons, named Ilì-ahì and Warassuni. After the deal had been closed Ginunu remarked that Dan-ili had no barley left. The rest of the tablet apparently concerns the freeing of Ilì-ahì, who came to an agreement with Dan-ili by "measuring" (that is, giving) for him a "chair house" (see discussion on line 18) in place of the barley for which he was originally sold.

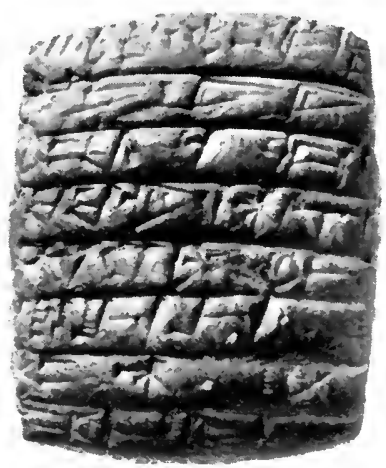

Obverse

TABLET 8 (FM 229254)

Transliteration and Translation

Obv. 1) 1 A-dam-u DUMU 1 Adam $^{\prime} u$ son of Pu-ili, $P \grave{u}-\grave{i}-l i ́$

2) [1] Al-i-lí

3) DUMU Su-ba-̀̀

[1] Al-ilī son of Subae,

4) $1 Z u-z u$ ARÁD

1 Zuzu slave of Innin, 'Innin

5) $1 \mathrm{Hu-mi-zum}$ UH.ME

6) 1 E-da-da

1 Humizum the GUDU-priest,

7) DUMU DINGIR$\mathrm{KÀR}$

8) $\mathrm{AB}+\overline{\mathrm{A}} \check{\mathrm{S}}$ en-ma

1 Edada

son of Ilum-KĀR.

Witnesses (to the fact) that thus (said) 


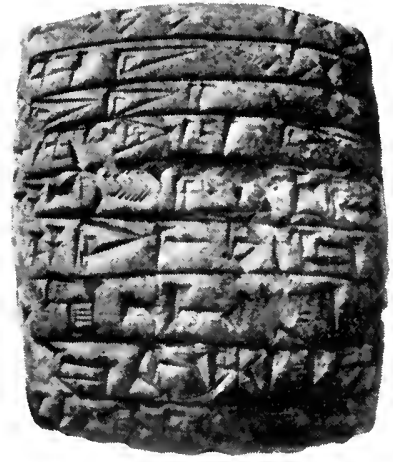

Reverse

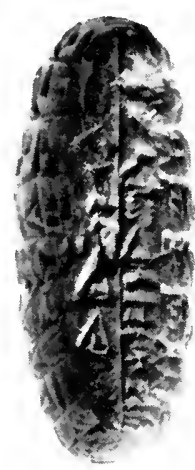

Left Edge

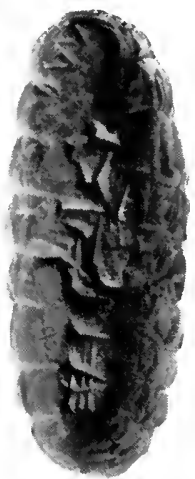

Right Edge

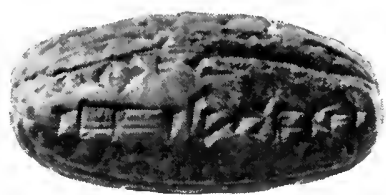

Lower Edge

TABLET 8 (FM 229254)

Rev. 9) Gi-nu-nu a-na

10) Dan-i-li

11) $\bar{I}-l i-a-h i$

12) $\grave{u} \mathrm{ARA} \mathrm{D}-z u-n i$

13) $a-n a$ ŠE $a t-t i-k u m$

14) a-ni-me mim-ma-su

15) la ti-su

16) $m a-h a-a r-s ̌ u-n u$

17) $a-n a$ ŠÁM ŠSE

Lo. E. 18) 1 É.GU.ZÉ

L. E. 19) $I-l i-a-h i$

20) a-na Dan-i-li

R. E. 21) $i \breve{s}-d u-u d$
Ginunu to

Dan-ilì:

Ilì-ahì

and Warassuni

I gave (sold) to thee for barley.

Now thou hast nothing of it (left).

Before them for the price of barley 1 "chair house"

Ilì-ahì for Dan-ilī measured.

\section{NoTES}

Line \%.-With our name DINGIR-KÀR cf. İ-lum-KÀR, DINGIR-su-KÀR (Ungnad, MVAG XX 2, pp. 32f.), Be-lí-KÀR (ibid. p. 46), Sar-ru-KÂR (Meek, HSS X 169:2 and 6), d $\grave{I} r-r a-K A ̄ R$ 
(MAD I 163 viii 8), $E \check{s}_{4}$-dar-KÀR (MAD I $163 \times 13$ ), etc., in which KÀR probably represents a logogram with an unknown Akkadian equivalent. The interpretation of qar as being from waqar or jaqar is possible but for the present not provable.

Line 12.-The frequently used personal names Warassuni and Amassuni (see Index) are archaisms from a period in which such a compound was conceived as warad ("slave," nom. in construct state) and šuni ("of them," in gen.). The normal form for "their slave" in the Old Akkadian period is warassunu in the nom. and warassuni in the gen.-acc. (but also warassunu is already used). These examples show again that personal names frequently preserve older forms no longer used in the contemporary language. On other archaistic features see the discussion under no. 49:12.

Line 14.-Our a-ni-me corresponds most probably to the Nuzi expression $a$-an-ni or $a-a n-n i-m i$ used in direct discourse, with the meaning "now." Cf., for example, um-ma ${ }^{\mathrm{m}} \mathrm{Ku} u$-a-ri-ma $a$-an-ni-mi 7 ANŠE A.ŠAG ${ }_{4} a$-šar ${ }^{\mathrm{m}} G e-e l-t e-s ̌ u p ~ i k$-ta-la-mi, "thus (said) Kuari: 'Now I (sic!) held back 7 imēr of field from Kel-tešup'," in E. Chiera, Joint Expedition with the Iraq Museum at Nuzi (American Schools of Oriental Research, "Publications of the Baghdad School," Texts), IV (Philadelphia, 1934) 340:13ff.; cf. also the occurrence of this word in similar passages in lines 20 and 27 . For other occurrences see C. H. Gordon in Orientalia, n.s. VII (1938) 228, who translates the word as "yes."

Use of the particle - $m i$ (written as -me) for direct discourse is frequent in the Old Akkadian period. Cf. the examples cited in Ungnad, $M V A G \mathrm{XX} 2$, p. 66, under mimmî, where Ungnad's salam mi-me and šum mi-me are to be interpreted, following Landsberger in $Z A$ XXXV (1924) 216, as șalmī-me and šumì-me respectively.

The sign $s u$ is not very clear on the tablet; nevertheless, it can be safely read in view of such forms as $m i-i m-m a-s ̌ u$ in the later period (see, for example, von Soden in $Z A$ XL [1931] 204). On the construction mimma iš $\hat{u}$, "to have anything," see Delitzsch, $A H W B$ 418b. Cf. also the personal name Mim-ma-sa, discussed under no. $37: 5$.

Line 18.-The sense of the whole tablet hinges upon the correct interpretation of the expression 1 E.GU.ZE. Originally I took it to be a personal name, Eguze, inserted on top of line 1 as an addition to the list of witnesses. Against this interpretation militated the fact that I could find no such personal name in any other sources. 
Furthermore, such an explanation, involving, as it did, a later insertion of the name, and that in an unusual place on the tablet, seemed forced. And finally, it would mean that in taking ma-ha$a r-s ̌ u-n u$ a-na ŠÁM ŠE İ-lí-a-hi a-na Dan-i-li iš-du-ud, "before them for the price of barley he (namely, Ginünu) measured out Ilī-ahì for Dan-ili,", we would be forced to reckon with the omission of the name Warassuni in this phrase. Observe that according to lines 11-13 two men, Ilì-ahī and Warassuni, were sold to Dan-ilì for barley.

The new interpretation proposed below is based on comparison with an Old Akkadian tablet concerning ŠU.NIGÍN 4 É.GIŠ.GU. ZA šu-ut (names of 4 men) iš-du-tu, "a total of 4 É.GIŠ.GU.ZA which (4 men) measured" (MAD I 336:6-12). It seems very probable that the É.GIŠ.GU.ZA of $M A D$ I tablet is comparable to the É.GU.ZE of our tablet. The omission of the determinative is attested in the example E.GU.ZA (De Genouillac, ITT III 5626:2) and in 1 É.GU.ZA KUŠ SI.GA ( $R A$ XVI $20 \mathrm{x}$, xii, xiii; the latter example shows that E.GU.ZA can be covered with leather).

In Old Akkadian the word for "chair" appears in 30 gu-zi-ù TUR, “30 small chairs," in Scheil and Legrain, Mém. XIV 8:4. This word appears also in Cappadocian in the form kussi um, as, for example, in Gelb, OIP XXVII p. $57 \mathrm{n}$. to line 28. The Old Akkadian and Cappadocian form kussi um presupposes the existence of a Sumerian form ending in $-i$ or a similar vowel. Sumerian GU.ZA would have resulted in kussa $u m$ in Akkadian, which is found in the dialectal form $k u-z a-u$ in $C T$ XVIII $3 \mathrm{v} 2$. Our form GU.ZÉ (the reading GU.ZI or the like, is possible) is evidently the one which corresponds to the Akkadian kussi um.

In the New Babylonian period bît kussî, "chair house," written É.GIŠ.GU.ZA, is frequently found in connection with bît sîs $\bar{\imath}$, "horse house," and bît narkabti, "chariot house" (VAS 128:10; XV 3:14; Clay, Legal Documents from Erech, "Babylonian Records in the Library of J. Pierpont Morgan" II [New York, 1913] 10:12; $P B S$ II 65:14). Ungnad in Glossar to San Nicolò and Ungnad, Neubabylonische Rechts- und Verwaltungsurkunden I (Leipzig, 1937) p. 76, translates bît kussî as "Stuhlhaus" (possibly "Weberei"). W. Eilers in Orientalistische Literaturzeitung XXXVII (1934) 94, understands the three New Babylonian expressions as representing three different types of feudal bondage.

For the sake of completeness it may be noted that some Old Akkadian texts (for example, $M A D$ I 226, 233, 234) mention men 
belonging to GIŠ.GU.ZA or GIŠ.GIGIR (for example, $1 \check{S}$ a-at-beDINGIR 1 U-da-tum ša [dual] GIŠ.GU.ZA).

Line 21.--On the meaning šadaddum, "to measure" and "to measure off," see n. to no. 1:12. 

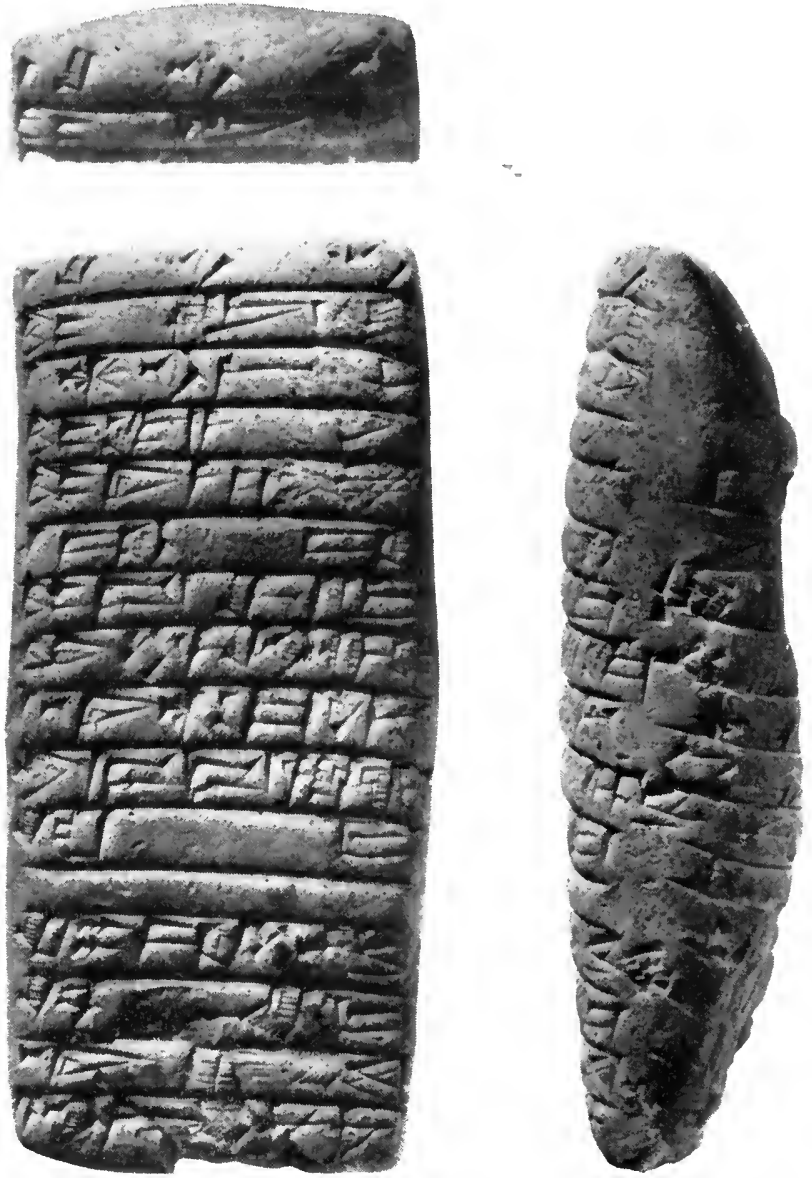

Obverse

TABLET 9 (FM 229206) 


\section{9 (FM 229206)}

Obverse is very well preserved; reverse has signs preserved only at beginning and end of each line. This tablet may have been written by the same scribe as the one who wrote tablet no. 14 (q.v.).

Five men, identified by their genealogies and professions, bear witness that Bêlī-šadû made a statement under oath to Ginunu. The contents of this oath are difficult to reconstruct because of the bad preservation of the reverse. The tablet ends probably with the phrase "the rest of the silver is upon him," that is, he owes the rest of the silver (lines 26-29).

\section{TRANSLITERATION}

Obv. 1) $1 \check{S} u-N a-n a$

2) DUMU Al-lum

3) 1 DINGIR-na-zi-ir

4) DUMU KA-Me-ir

5) DUMU İ-me-Dur-ùl

6) $1 Z \dot{e}-z \dot{e}$

7) DUMU $I m_{\mathbf{x}}(\mathrm{DU})-d a-l i k$

8) LÚ.MUN ${ }_{\mathrm{x}} \check{s} i \check{S} u-n a-a k-p u m$

9) 1 Be-lí-AN.DÙL NAGAR

10) ARÁD $D u$-du ši E-la-me-tum

11) $\check{S u-u m ~ I B ~}$ (space)

12) ŠU.NIGÍN $5 \mathrm{AB}+\mathrm{A} \breve{S}-b u$-tum

13) šu-ut en-ma

14) $B e-l i$-sa-tu

15) a-na Gi-nu-nu 


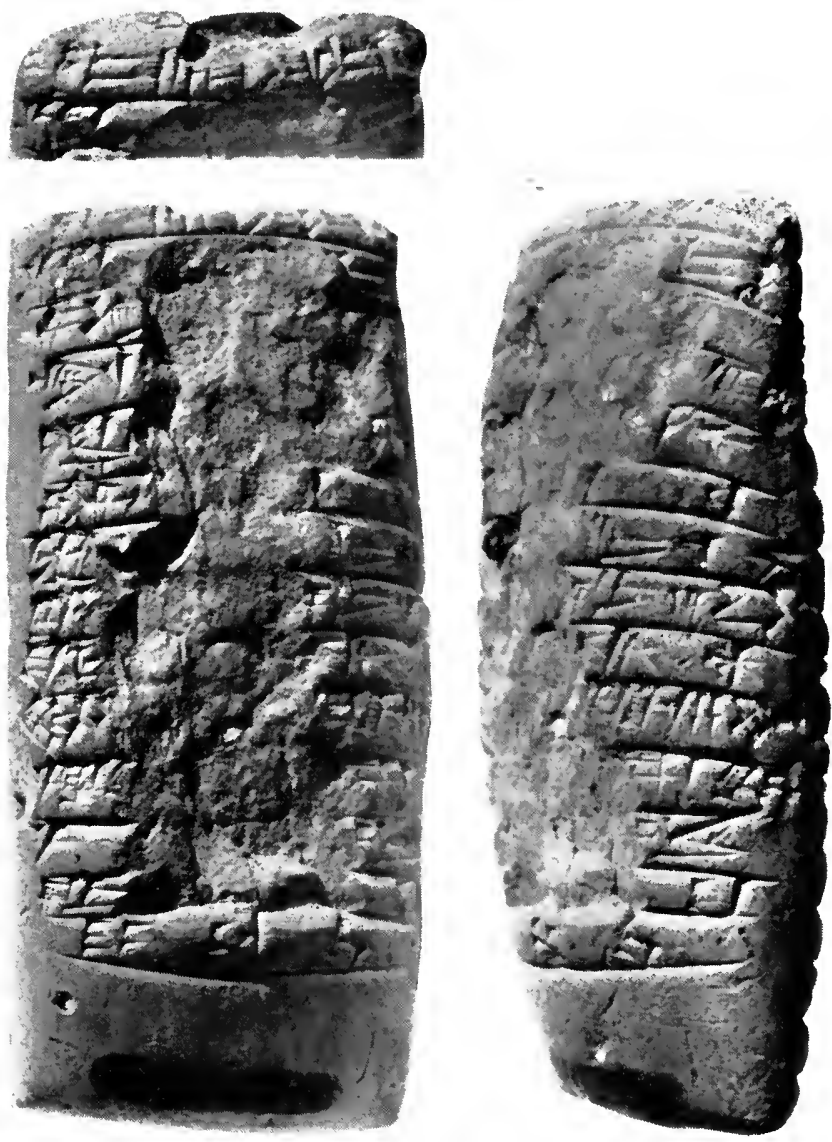

Reverse

TABLET 9 (FM 229206)

TRANSLITERATION

Rev. 16) $\mathrm{BĀD} A-g a-d \grave{e}^{\mathrm{KI}}$

17) $\grave{u}-[. . .] ?-.m a$

18) $\breve{S} u[m-m a-s] a$

19) ARĀD [Gi-nu-u]šs-sa-am

20) $i l_{x}-[\ldots]-n u$

21) $i m-[d] u-u d$

22) DAM-[....]-x

23) $l u-.[. .]-.a l-k u m$

24) $s u-m[a-\ldots . t] u-g i-i l$ 
25) KUG.BABBAR $b[u-. . .] l u d a-.z a-b u$

26) ù KUG.B[ABBAR ... . G]IIN KUG.BABBAR

27) $\check{s} i$-[....]?-tum

28) al-[...]?-su

29) $i$-ba-se 11

\section{Notes}

Line 4.-For the personal name KA-Me-ir see n. to no. 2:5.

Line 8.-The profession LÚ.MUN ${ }_{\mathrm{x}}(\mathrm{BULUUG})$ probably corresponds to the more common LÚ.MUN ${ }_{x}$.SAR. Cf., for example, $\mathrm{MUN}_{\mathrm{x}}$ alone in the list of professions in Meek, HSS X 222 ii 6, and the common $\mathrm{MUN}_{\mathrm{x}} . \mathrm{SAR}$ in Meek, op. cit. p. xl. Since $\mathrm{MUN}_{\mathrm{x}}$

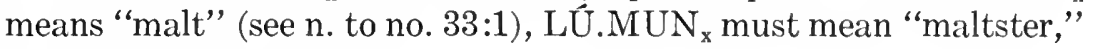
that is, "maker of malt."

The sign PUM in the personal name $5 u-n a-a k$-pum here as well as in no. 14:8 differs somewhat from the normal form, but in spite of the difficulties surrounding the interpretation of the name as a whole, the reading of this particular sign seems sure. I see now that this name occurs also in the form $\breve{S} u-n a-a k-p u$ in texts of later date published in $C T$ VIII 10b 2 and 14a 2.

Line 11.- The personal name $\breve{S} u-u m$ is possibly to be interpreted as šu'um, "ram."

The title or profession IB occurs also in Chiera, Selected Temple Accounts from Telloh, Yokha, and Drehem ("Cuneiform Tablets in the Library of Princeton University" [no date]) 14 i 6 and 16 i 5. For IB.GAL with the Akkadian equivalent muirru, "director," see Deimel, $\breve{S} L$ II 535:22.

Line 16.-With our BÀD $A-g a-d \grave{e}^{\mathrm{KI}}$ ef. $\mathrm{BÀD}-{ }^{[\mathrm{d}} A-g a-d \grave{e}$ in an Old Akkadian tablet from Susa published in Scheil and Legrain, Mém. XIV 8 rev. 4, and in a later text ${ }^{\mathrm{URU}} \mathrm{BA} D-A-g a-t i$ in Scheil, Mém. XXVIII 533:25.

Line 24.-With $t u$-gi-AN in our text cf. $u$-gi-AN in Meek, HSS $\mathrm{X}$ 94:11. The reading $t u-k i$-il or $u$-ki-il seems probable.

Line 25.- Instead of $l u d a-z a-b u$ we might read ' $\dot{u}^{\top}-d a-z a-b u$ and interpret it as $\hat{u} t a s ̦ s a p \bar{u}$, a II 2 formation of ${ }_{6}$ ȘP, "to increase," "to add." 


\section{0 (FM 229233)}

Declaration of Manunu before four witnesses of his willingness to pay the rest of a price to Ginunu. Although the tablet is imperfectly preserved, the reading of all the signs is relatively certain.

\section{Transliteration and Translation}
Obv. 1) I-da-ra-ak
2) $\check{S} u$-um
3) SIPA!-tum
4) $M a-s ̌ u[m]$
5) $\mathrm{AB}+\overline{\mathrm{A}} \breve{\mathrm{S}}$ en-ma

Rev. 6) $M a-n u-n u$

7) $a-n a G i-n u-n u$

8) in É ši uš-da-a-bí-la

9) a-na si-tim ŠÁM-me

10) $l u-u \check{s}-k u-u l-k u m$

11) al-kam-ma

L. E. 12) $b a-d a m$
Itarrak,

Šu’um,

Rēîtum,

Mašu[m].

Witnesses (to the fact) that thus (said)

Manunu

to Ginunu:

In the house, in which I had reconsidered (the matter)

the rest of the price (literally: to/for the rest, the price) let me weigh out for you. Come and

\section{Notes}

Line 3.-The text has PA.KU-tum, which is most probably to be emended to PA.LU!-tum=SIPA!-tum. For this name see n. to no. $6: 4$.

Line 8.--The verb šutâbulu, "to think over," "to consider," for which see T. Bauer, Das Inschriftenwerk Assurbanipals II (Leipzig, 1933) 84, and idem in $Z A$ XLII (1934) 168, n. 1, does not fit our case, since the expected form in Old Akkadian should be uštûbila, because of such forms as ušûșî (see Ungnad, MVAG XX 2, p. 53). I am inclined to interpret our form as derived from the root 'PL.

On the subjunctive form ending in $-a$ see the discussion to no. $1: 12$.

Line 12.- In view of the polyphonic character of the signs it is not easy to find the verb which underlies the writing ba-dam. Possibly the form is the imperative of $\mathrm{B}_{7}{ }_{7} \mathrm{~T}$ or $\mathrm{B}{ }_{7} \mathrm{D}$, "to spend the night." Some such translation as "come and spend the night" would fit the context. Although the expected imperative with allative should 


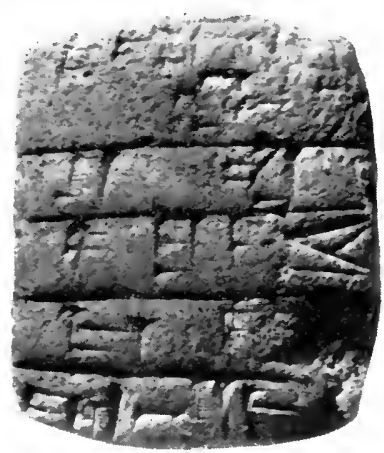

Obverse
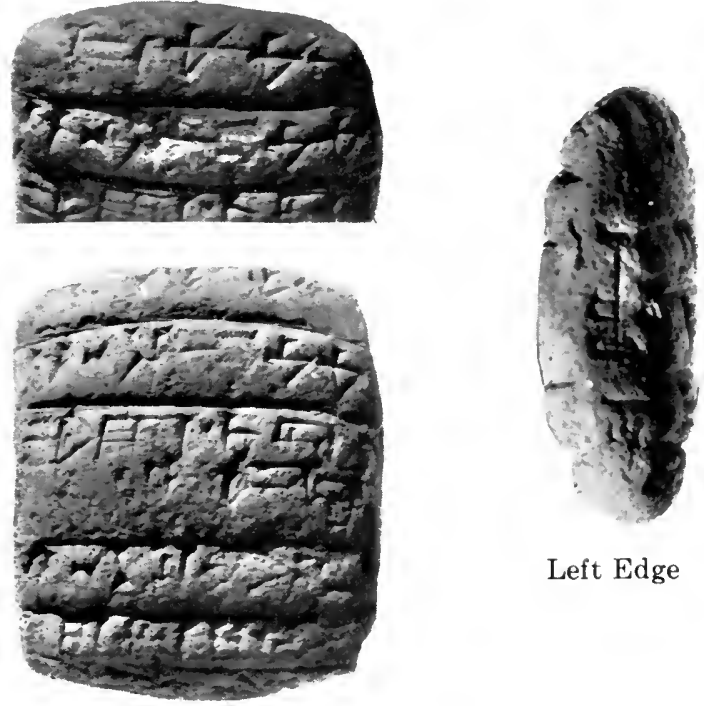

Left Edge

Reverse

TABLET 10 (FM 229233) 
not be bâtam but bitam, because of such existing preterit forms as $i b \hat{\imath}$, Arabic has both jabâtu and jabittu, and it is possible that Old Akkadian too may have formed a preterit ibôt besides later ibit. However, until such forms can be attested for Old Akkadian the translation "to spend the night" must remain doubtful. 


\section{1 (FM 229220)}

The interpretation of this tablet presents no little difficulty, chiefly because of the uncertainty in determining which is the obverse and which the reverse of the tablet.

Originally I understood the tablet as dealing with two excavations, one in the back, the other in the front of a certain spot. Ur III tablets dealing with excavations are well known. Some of them are noted in Deimel, $\check{S} L$ II 371:8. Militating against this interpretation was, first, the resultant abnormal order in which the inscription would have to be read by considering as obverse the side which should be taken as the reverse and, second, the lack of a parallel example which might justify taking $G u-u t-n u-u m$ as a personal name.

I believe that by reading the inscription in its normal order, as proposed here, a better understanding of the inscription is made possible. If we eliminate $G u-u t-n u-u m$ as a personal name, no other possibility remains but to take it as an appellative noun kutnum ( $q / g$ and $d / t$ also possible), which occurs twice in an Old Babylonian document discussed by P. Kraus, MVAG XXXVI (1932) p. 192. This word there denotes some kind of woolen cloth for making garments.

According to this new interpretation, then, the tablet enumerates the names of four witnesses who testify that they heard that Ginunu declared something to a man whose name ends in -ratum. What Ginunu said is mentioned in lines 8-15. In lines 8-13 is mentioned the cloth together with its measurements. What became of this cloth or what was to be done with it is stated in lines $14 \mathrm{f}$., which are unfortunately so badly preserved as to be unintelligible.

The size of the cloth is given as being about 6 meters long and 1.5 meters wide in the back, and 1.5 meters long and 1.5 meters wide in the front. Hence it seems to have been in two pieces.

A parallel to our text is found in a New Babylonian tablet published in T. G. Pinches, Inscribed Babylonian Tablets in the Possession of Sir Henry Peek, Bart. (London, 1888) no. 2, according to which a certain man owes a temple a specified amount of linen, to be returned within two months in two lots of three pieces each; each piece is to be 12 cubits long and 4 cubits wide. 


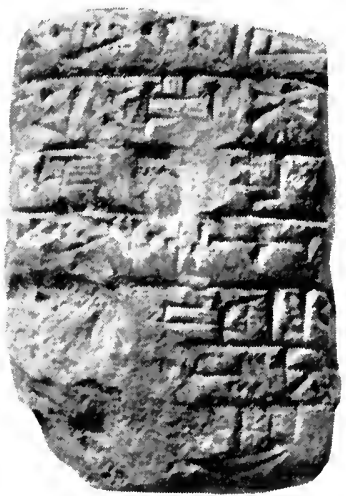

Obverse
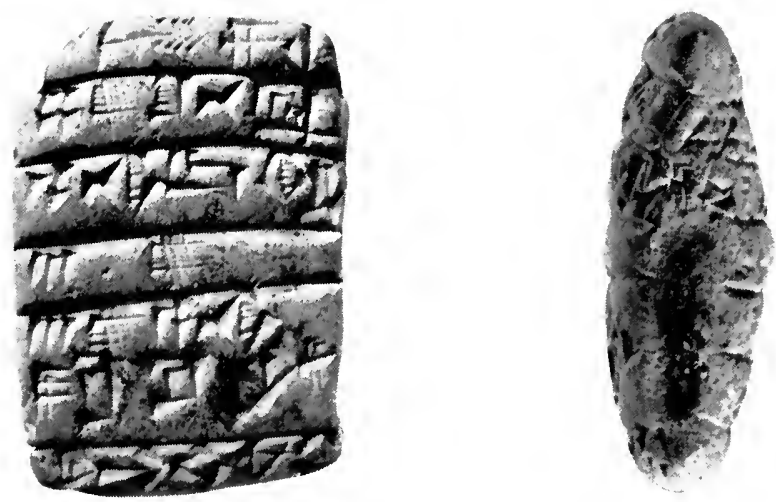

Reverse

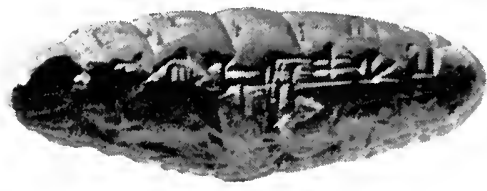

Left Edge

TABLET 11 (FM 229220) 


\section{Transliteration and Translation}

Obv. 1) ARÁD-zu-ni

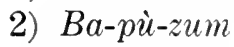

3) $S a$-[ti]-um

4) ARĀD- ${ }^{\mathrm{d}}$ Innin

5) [S̆U.NIGÍN 4]

$\mathrm{AB}+\overline{\mathrm{A}} \breve{S} \check{s} u-u t$

6) $[e n-m a] G i-n u-n u$

7) $[a-n a \ldots . .] ..-r a-t u m$

Rev. 8) '2' GI UŠ

9) 4 KǙ ŠU.BAD

DAGAL

10) $a-n a u r-k i-i m$

11) $3 \mathrm{KU \check {S }}$

12) 3 KỨ $a$-na ra-si-im

13) $g u-u t-n u-u m$

L.E. 14) [x] Šum-ma-sa PA. TE.SI

15) [. . . .]. al İ-lí-DIRIG
Warassuni,

Babuzum,

Šadium,

Warad-Innin.

[Total of 4] witnesses (to the fact) that

[thus] (said) Ginunu

[to.......-ratum:

'21 GI long,

4 KÜS (and 1) ŠU.BAD wide

in the back,

3 KÜS (long),

$3 \mathrm{KUSS}$ (wide) in the head (or front)

cloth.

[. . . . S Šmmaša the governor,

[. . . .] upon Ilī-watar.

\section{Notes}

Lines $5 \mathrm{ff}$.- The reconstruction of these lines is made possible by comparison with similar occurrences, such as ŠU.NIGÍN 5 $\mathrm{AB}+\overline{\mathrm{A}} \breve{S}-b u$-tum šu-ut en-ma Be-lí-sa-tu a-na Gi-nu-nu, "total of 5 witnesses (to the fact) that thus (said) Bêlī-šadû to Ginunu" (no. $9: 12-15)$.

Line 10.- Since in the text $u r-k i$-im and $r a-s i-i m$ are regarded as opposites, it is clear that the former cannot be from the root ${ }_{1} \mathrm{RK}$, "to be long," but from the root ${ }_{6} \mathrm{RK}$, "to be behind." The form ra`šum or râšum for "head" is of course the expected old form of rêsum. The same old form occurs in an inscription of Samsu-iluna: $r a-s i-s ̌ u-[n u]$ and $[r a]-s i-i n$ in the dual in L. W. King, The Letters and Inscriptions of Hammurabi II (London, 1900) 69 and 103, as compared with re-šsi-šu-nu and re-ši-in in a variant text published in $V A S$ I 33 iii 17 and iv 16.

Line 14.- There is space for one sign only in front of $\check{S} u m$-ma-sa. Supply perhaps $a l$, su, or $\grave{u}$ ? In taking $\breve{S} u m-m a-s a$ as a personal name I follow the advice of Dr. Jacobsen. A name Sum-ma-sa occurs possibly in an Old Akkadian tablet, $M A D$ I $282: 9$ and above in no. 9:18. On the ending -ša ef. note to our no. 33:40. 


\section{2 (FM 229222)}

The inscription begins with a list of eight men, with genealogies and professions, who serve as witnesses "(to the fact) that before them thus (said) Îdâ-pi-ili the foreman [to Ginu]nu” (lines 16-18). What he said was set forth in lines 19f. of the inscription, but this unfortunately is now mostly destroyed.

TransLiteration

Obv. 1) $1 I-d a-{ }^{\mathrm{d}} \mathrm{EN} . \mathrm{ZU}$

2) GAL.UKÜ

3) 1 A-ti-e MÁ.LAH ${ }_{4}$

4) 1 EDIN DUMU Pù-pì

5) $\check{s} i$ UR.UR

6) $1 \mathrm{En}$-[....]

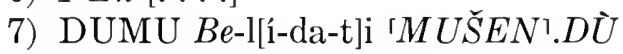

8) 1 DINGIR-UR.SAG

9) DUMU $\breve{S} u-M a-m a$

10) 1 I-dur-GI

Rev. 11) DUMU Bu-bu

12) 1 DINGIR-GI

13) 1 Gu-gu-za-núm

14) MUŠEN.DÜ

15) ŠU.NIGÍN $8 \mathrm{AB}+\overline{\mathrm{A} S}$

16) $\check{s} u-u t m a-h a-a r-s ̌ u-n u$

17) [en-ma] $I-d a-[b] i-i-l i$ UGULA

18) $[a-n a$ Gi-nu]-nu

19) $[\ldots . .-n] a$

20) $[\ldots . .]-.s a$ 

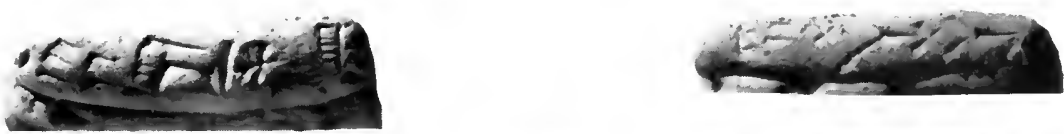

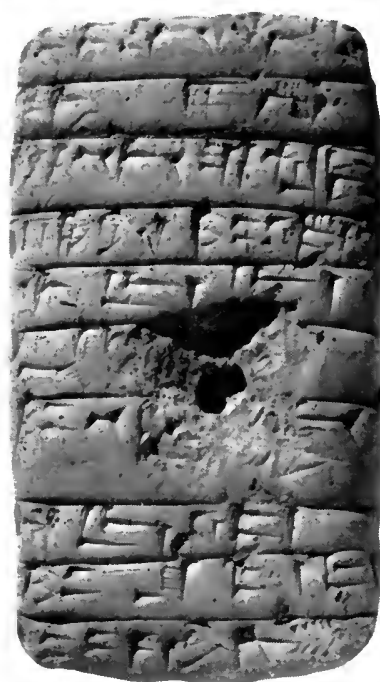

Obverse
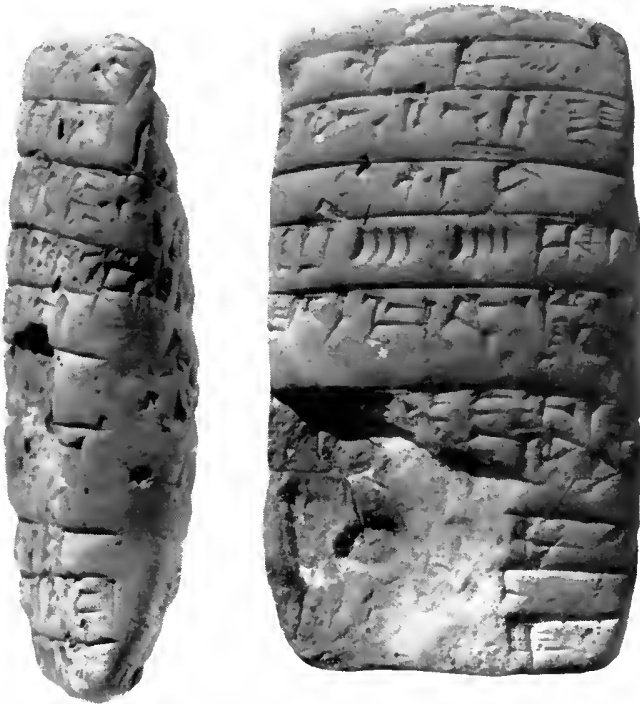

Reverse

TABLET 12 (FM 229222) 


\section{3 (FM 229243)}

Obverse to a great extent readable; reverse mostly worn and undecipherable.

\section{TRANSLITERATION}

Obv. 1) DINGIR-SIPA

2) NAGAR ARÁD-d Tišpak

3) A-bi-bi

4) $a-h u$ NU.BANDA

5) Nu-um URUDU.X

Rev. 6) $3 \mathrm{AB}+\bar{A} \check{S}$

(rest unreadable) 


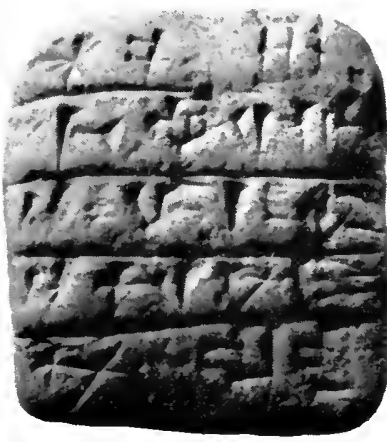

Obverse

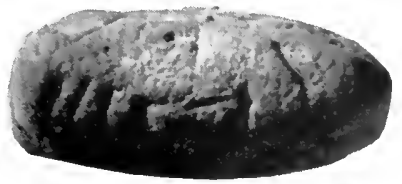

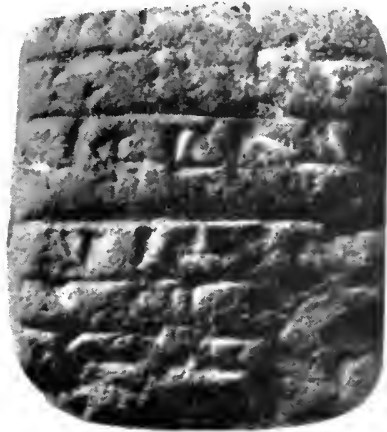

Reverse

TABLET 13 (FM 229243) 


\section{4 (FM 229232)}

Obverse badly preserved, reverse almost entirely broken away. Interesting is the phrase Gi-nu-nu $\dot{u} \mathrm{AB}+\overline{\mathrm{A}} \mathrm{S}-b u-z u$, "Ginunu and his witnesses," in lines of 10f., recalling the frequent use of reliable witnesses cited by Tehip-tilla, the great "capitalist" of Nuzi, in his numerous business transactions. The handwriting, color of clay, and form of this tablet closely resemble the respective features of no. 9 .

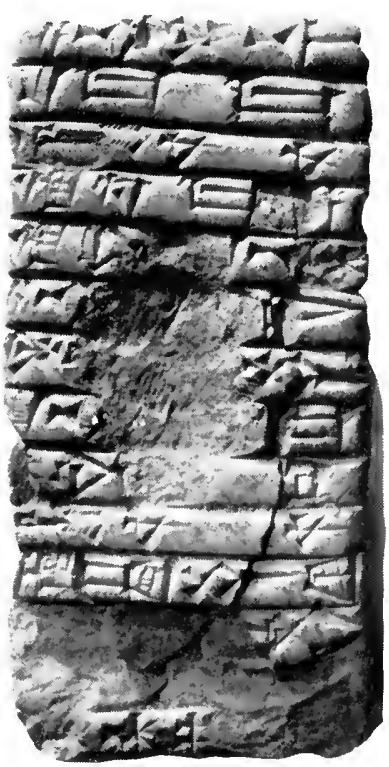

Obverse

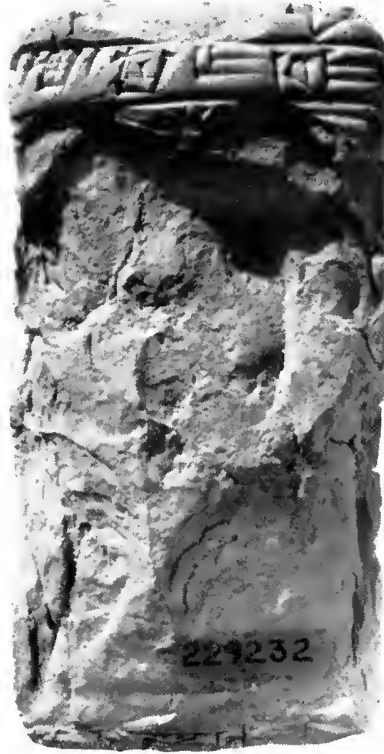

Reverse

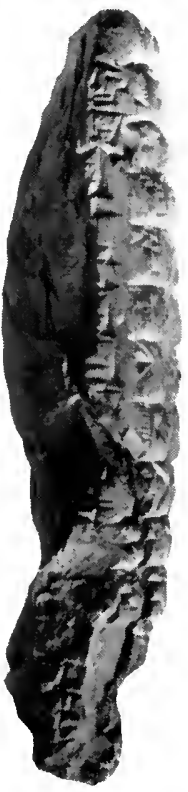

Left Edge

TABLET 14 (FM 229232) 


\section{TRANSLITERATION}

Obv. 1) a-na 1 Zum-ti

2) $\check{S} u-M a-m a$

3) 1 Gi-nu-nu

4) ̀̀ $H u-m a-[z] a$

5) ̀̀ $\breve{S} a-[a] t-b e-D I N G I R$

6) $a-n a[\ldots]-n i$

7) GEME.....]-bu-ma

8) $\breve{S} u-n a-[a k]-p u m$

9) PA.TE.SI

10) $G i-n u-n u$

11) $\dot{u} \mathrm{AB}+\overline{\mathrm{A}} \mathrm{S}-b u-z u$

12) $[\ldots]$ - tim

13) $[\ldots$.

14) $[\ldots] \mathrm{AN}$ PA [....]

Rev. 15) [....]-nu

16) $\grave{u} E \check{s}_{4}$-dar-UR.SAG

17) ....

(about 11 lines destroyed)

29?) DUMU.SAL DINGIR-ba-ni

L.E. 30?) . . .-dam ik-su-ra 


\section{5 (FM 229215)}

If I understand the inscription correctly, the four men named at the head are witnesses that Ipte'um borrowed barley from Amat-Innin.

\section{Transliteration and Translation}

Obv. 1) '1'Dar-u-ma

2) 1 GEMÉ-zu-ni

3) $1 \grave{I}-z i-n a$

4) 1 A-li-li

Rev. (space)

5) ŠE GEMÉ- ${ }^{\mathrm{d}}$ Innin

6) $i \check{s}$-dè Ip-te-u-um
'1' Dar'uma,

1 Amassuni,

1 Izina,

1 Alili.
(Witnesses to the fact that) the barley of Amat-Innin

(is) with Ipte`um.

\section{Notes}

Line 1.-The personal name Dar-u-ma occurs also on the Old Akkadian tablet $M A D$ I 326:6.

Line 3.-For the personal name $\grave{I}-z i-n a$ see n. to no. 25:2. 


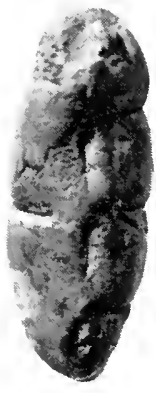

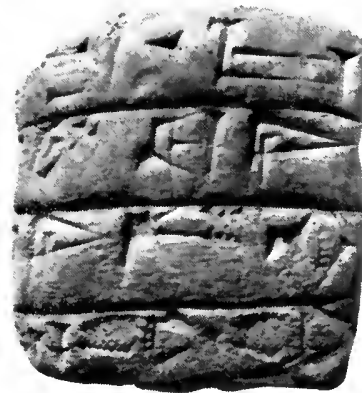

Obverse

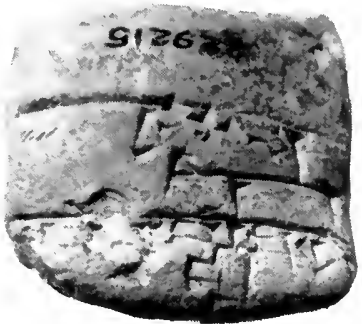

Reverse

TABLET 15 (FM 229215) 


\section{6 (FM 229226)}

Due to textual difficulties it is very difficult to grasp the sense of the inscription, and I have duly considered several possible interpretations before proposing the one below. According to this interpretation lines 1-8 list five or six men, together with their professions, who served as witnesses to the fact that Gāmirum received $1 \mathrm{PI}$ of barley. This interpretation is supported by the text of no. 3 , in which four men are witnesses that a certain person gave (sold) $1 \mathrm{PI}$ of barley to another person.

There is no clear proof that what I ultimately took to be the obverse of the inscription is really the obverse. But if we regard what I have called the obverse as the reverse and the reverse as the obverse, the sense is not improved.

\section{Transliteration and Translation}

Obv. 1) DAM İ-li-kára-bi

2) DUN.Ú

3) ARĀD $S a-a-m i$-iš

4) DINGIR- $a-z u$ DAM. $\mathrm{KÀR}$

Rev. 5) $E \check{s}_{4}$-dar-al-su

6) SIPA UDU

7) A-ma-rí-iš TÚG

8) $B a-n i$ UD.KA.BAR

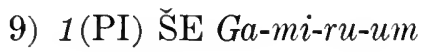

Wife of Ilì-karābì, DUN.Ú slave of Ša amiš, Ilum-asû the merchant,

Eštar-alšu the shepherd, Amariš the fuller Bānî the bronzeworker. (Witnesses to the fact that)

Gāmirum (received) $1 \mathrm{PI}$ of barley. 

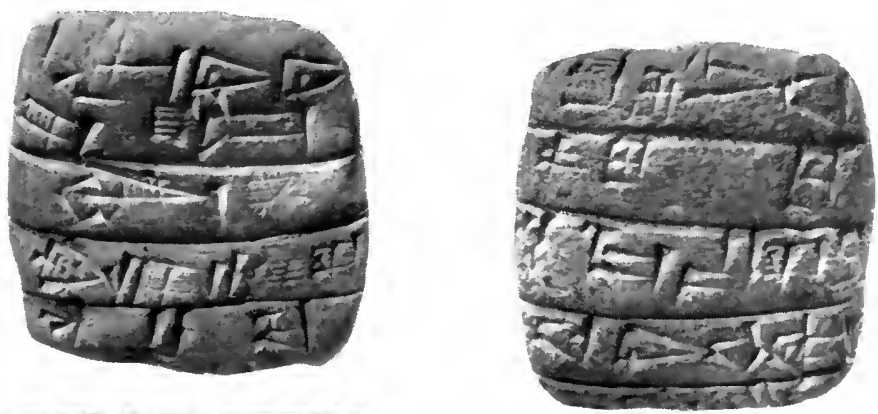

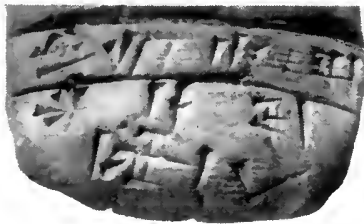

Obverse

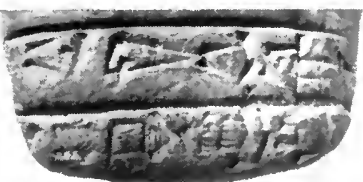

Reverse

TABLET 16 (FM 229226) 


\section{NoTES}

Line 1.- On such formations as DAM İ-lí-kára-bi, "the wife of Ilī-karābī," or simply "Mrs. Ilī-karābī," see note in Meek, HSS X p. xv. From elsewhere cf. DAM U-i-lí in Scheil, Mém. XXIV 342:26. The personal name $\dot{U}-\hat{i}-l i$ alone is found, for example, in Meek, HSS X 153 viii 28.

Line 2.-DUN.Ú is a grass-fattened pig, and as such it is often mentioned in the literature; see Deimel, $\breve{S} L$ II 467:28. As a personal name it occurs in G. Reisner, Tempelurkunden aus Telloh 149:3. On the unusual form of the sign DUN see above, page 177.

Line 3.-The ending - $i \check{s}$ of the personal name $S a$ - $a$ - $m i$-iš occurs also in $A$-ma-ri-iš 1. 7, $S a-a-n i$-išs no. 33:58, and in many other names outside our collection.

Line 7.-The profession TÚG or LÚ.TÚG is usually interpreted as "tailor"; see, for example, Deimel, $\breve{S} L$ II 536:76; H. Torczyner, Altbabylonische Tempelrechnungen (Wien, 1913) p. 118; B. Meissner, Babylonien und Assyrien I (Heidelberg, 1920) 256 and 466; P. Kraus, MVAG XXXV 2 (1931) 33. Gadd's translation in Iraq VII 33 and 58 and in Journal of the Royal Asiatic Society 1941 p. 285 (and elsewhere?) as "fuller" or "washerman" finds support in the equation $a z-l a-a g=\mathrm{LU} . \mathrm{KU}=a \dot{s}-l a-k u$ in the Princeton syllabary published in Journal of the American Oriental Society LXV (1945) 224:39. For the Old Akkadian period ef. also LÜ.TÚG in MAD I $161 \times$ x 7, 326 iii 9 and SAL.LÚ.TÚG in our no. 36:11.

Line 8.- One interpretation of ba-ni UD.KA.BAR is "maker of bronze." This profession could hardly apply to Amāriš in 1. 7, who is presumably a fuller. It is of course possible for one person to have two professions, but hardly such divergent professions as those involving making clothes and bronze. The root $\mathrm{BN}_{7}$ means "to build," "to create," and also "to make" in general (see Delitzsch, $A H W B$ p. 178a). Nevertheless, it is surprising that this verb and not 'PŠ should be used in connection with making bronze. In later periods the bronzeworker is called nappāh siparri (see Delitzsch, $A H W B$ p. $474 \mathrm{~b}$ ). In view of all these difficulties perhaps the simplest solution is to take $B a-n i$ as a personal name and to interpret UD. KA.BAR as his profession. On the personal name cf. Ba-ni-i in Tallqvist, Assyrian Personal Names pp. 51f. The reading BA NA <UD >.KA.BAR, "measure by the stone of bronze," (cf. no. 36:19) seems too far-fetched for consideration. 
Line 9.-With Ga-mi-ru-um in our text ef. Ga-me-ru-um in an Old Akkadian text, MAD I 176 rev. 4, and in M. V. Nikolskii, Drevnosti Vostochnyia ("Trudy vostochnoí kommissii imperatorskago Moskovskago arkheologicheskago obshchestva," vol. V [Moskva, 1915]) 83:8. 


\section{7 (FM 229212)}

Some of the personal names on this tablet are identical with those on nos. 18 and 19. All three tablets evidently belong to the same class of documents.

Six persons, listed in lines $1-6$, were witnesses who saw that Ašaša gave barley to Ešia (lines 7f.). The reverse is badly preserved, and the signs are much smaller than those on the obverse. I am unable to reconstruct the sense of this part of the text.

\section{TRANSLITERATION}

Obv. 1) $\check{S} u-u m$

2) $U \hat{U}-a$

3) ARÁD-zu-ni

4) $L i-l i$

5) $S u-n i$-tum

6) $\breve{S} u-i-l i-s u$

7) $\check{\mathrm{SE}} A$ - ̌sa-ša

8) $a-n a E-s i-a$

Rev. (space)

9) $\check{s} u$-ut KUG.BABBAR

10) $S u-n i$ - $[$ tum]

11) Tab-ni

12) $K i-z a-z a$

13) $A$ - ̌sa-řa

14) $D a-n i-a$

15) GEMÉ-...

16) $[a-n] a \mathrm{AB}+\hat{\mathrm{A}} \check{\mathrm{S}} \mathrm{UR} \mathrm{U}^{\mathrm{KI}}$ 


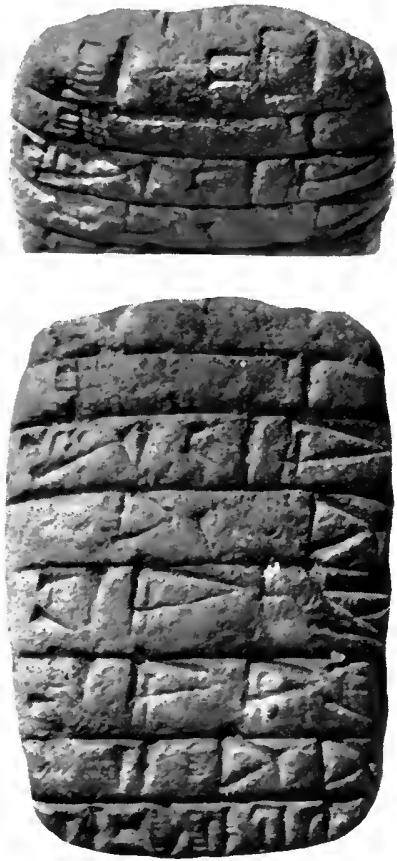

Obverse
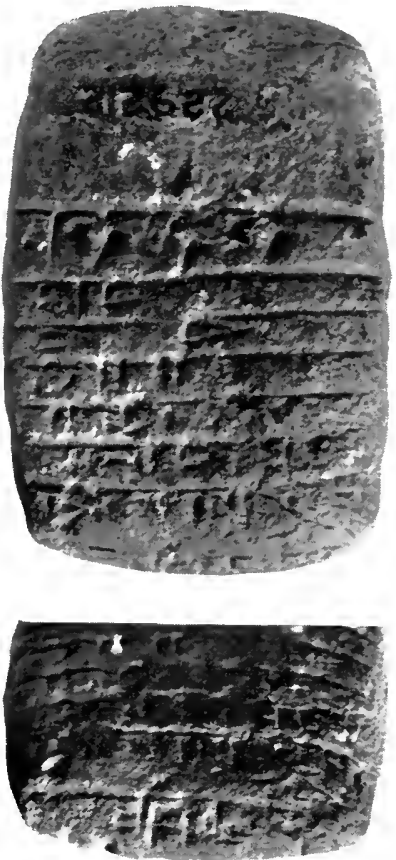

Reverse

TABLET 17 (FM 229212)

\section{NoTES}

Lines 7 and 13.- With $A$-ša-ša in our tablets cf. $A$-sa-sa in the Old Akkadian text $M A D$ I $116 \mathrm{x}+\mathrm{i}$. 
18 (FM 229211)

Some of the personal names in this text are reconstructed from comparison with nos. 17 and 19.

The persons named in lines 1-11 may have served as witnesses to the distribution of barley detailed in two columns separated by a vertical line in lines $12-21$. The scribe seems to have used certain abbreviations which cannot be understood today.

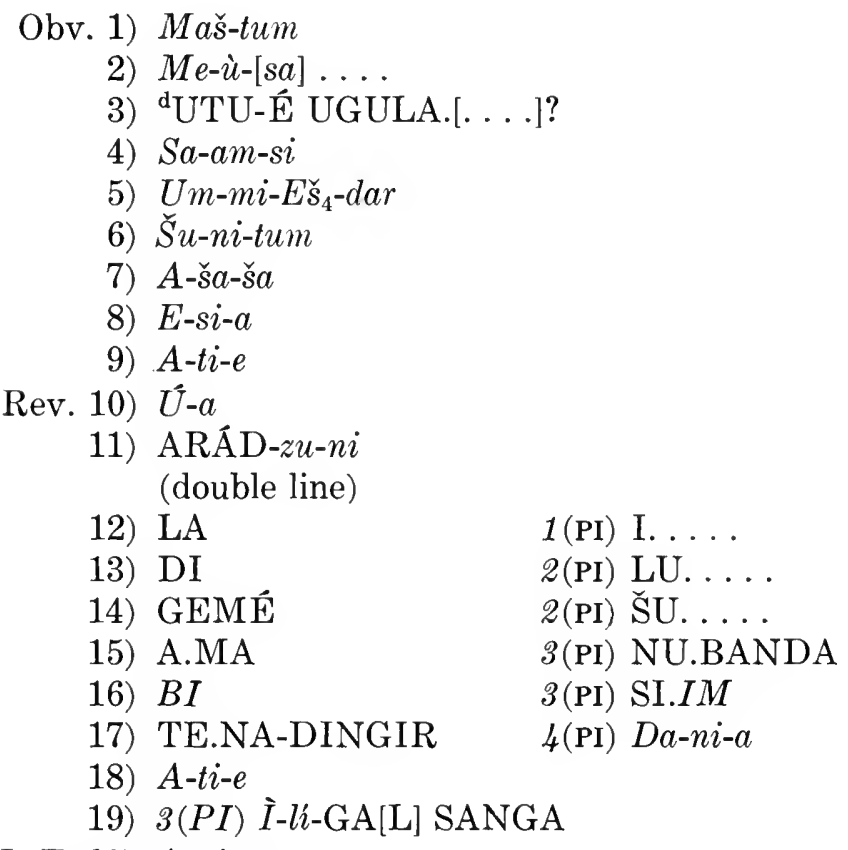

\section{Transliteration}

L. E. 20) $A-n i n-u$

21) DUMU ....-na-bí

\section{Notes}

Line 17.-The personal name TE.NA-DINGIR is found also on the Old Akkadian tablets $M A D \mathrm{I} 7 \mathrm{x}+\mathrm{ii}$ and $12 \mathrm{x}+\mathrm{ii}$. Read perhaps Paluh-ilim and ef. Ba-luh-DINGIR in Dossin, Mém. XVIII 76:5, Ba-luh-İr-ra ibid. no. 171:11, Ba-luh-É in Scheil and Legrain, Mém. XIV 72 iv, Ba-lu-úh-É ibid. 44:4. In later periods we have Šalim (SILIM)-pālih (TE.NA)- ${ }^{\mathrm{d}} A d a d$ and the variant $\check{S} a-l i-i m-b a-l i-i h$ ${ }^{\mathrm{d}} A d a d$ in Nuzi texts; see Gelb, Purves, and MacRae, OIP LVII s. $v$.

Line 20.-The name $A$-nin- $u$ occurs also on the Old Akkadian tablet $M A D \mathrm{I} 22 \mathrm{x}+\mathrm{i}$. Comparison with $I$-nin-um and $I$-nin-num 


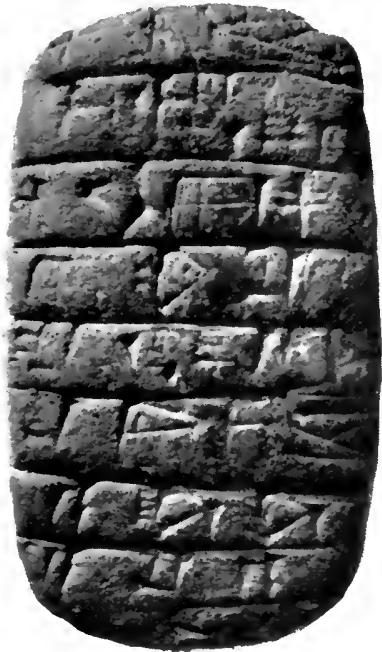

Obverse

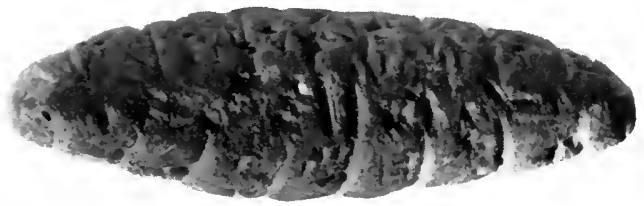

Left Edge
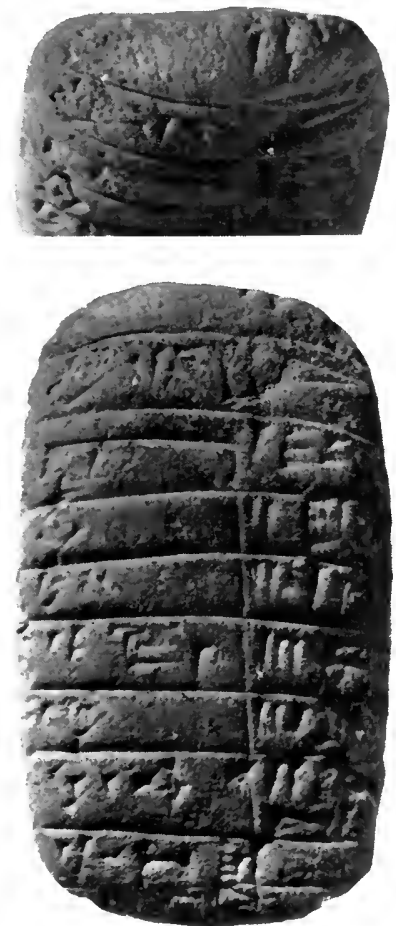

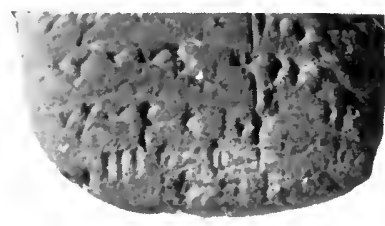

Reverse

TABLET 18 (FM 229211)

(discussed under no. 2:7) suggests that the writing $A$-nin- $u$ in our text is intended for Aninnu. Cf. also similar spellings in the names $A$-dam-u, Dar-e-tum, and Dar-u-ma. Dr. Jacobsen plans to prove in a future article that such broken writings are often intended for double consonants. 


\section{9 (FM 229204)}

The inscription is incompletely preserved. The damaged personal names can in many cases be reconstructed from comparison with nos. 17 and 18, which contain similar or identical lists of personal names.

The personal names in lines 1-14 may belong to persons who served as witnesses that Ašaša gave something to the elder of the city (lines 15f.). What he gave, in what amounts, and for whom is described in lines 17-20, which are divided into two columns by a vertical line. This inscription, like no. 17, may concern distribution of barley.

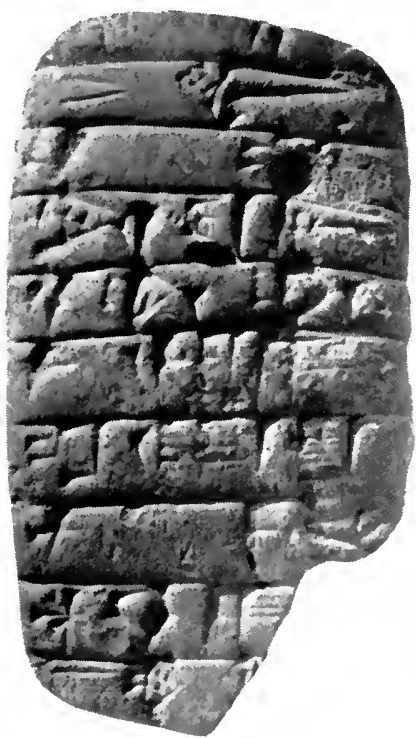

Obverse

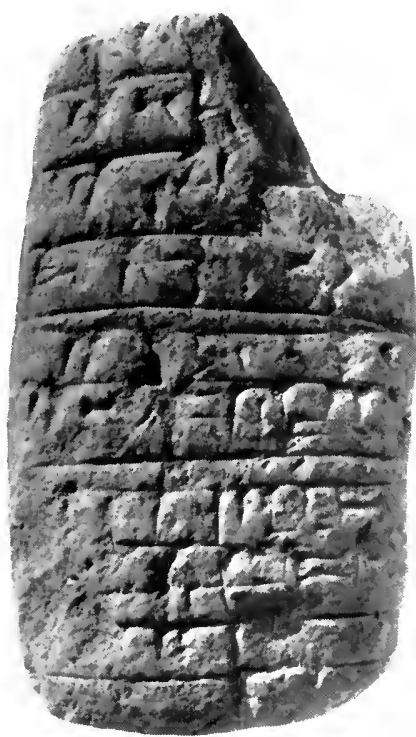

Reverse

TABLET 19 (FM 229204) 


\section{Transliteration}

Obv. 1) $\hat{U}-a$

2) $\backslash \grave{I}-l u l$

3) $\check{S} u-u[m]$

4) ARÁD-zu-ni

5) $A-\check{s} a-\check{s} a$

6) $M e-\grave{u}-s a$

7) $U m-m i-E \check{s}_{4}$-dar

8) Maš-tum

9) dUTU-[É] [UGULA ......]?

10) $S a-a m-s[i]$

Rev. 11) $S u-n[i-t u m]$

12) $A-t[i-e]$

13) $E-s i-[a]$

14) $\bar{I}-z i-n a$

(double line)

15) $A$-šsa-ša

16) $a-n a \mathrm{AB}+\overline{\mathrm{A}} \check{\mathrm{S}} \mathrm{URU} \mathrm{U}^{\mathrm{KI}}$ (double line)

17) $\ldots 1(P I) E \check{s}_{4}$-dar-GAL

18) $\ldots \quad 1(P I) E \check{s}_{4}$-dar-du-gul-t[i]

19) ... 2 $2(P I) \ldots$

20) $\ldots 2(P I) \ldots$

NoTE

Line 2.- On the relationship of $' \grave{I}-l u l$ to $\grave{I}-l u$-lu (see Index) cf. that of $A$-lul to Alulu (Schneider in Orientalia XXIII 13f.). 


\section{0 (FM 229210)}

The subject of this text is the distribution of something measured in PI's and QA's among various men and women. Most probably it is grain that is being distributed, and since the most important grain in Babylonia was barley we may further assume that our tablet concerns various allotments of barley.

\section{Transliteration and Translation}

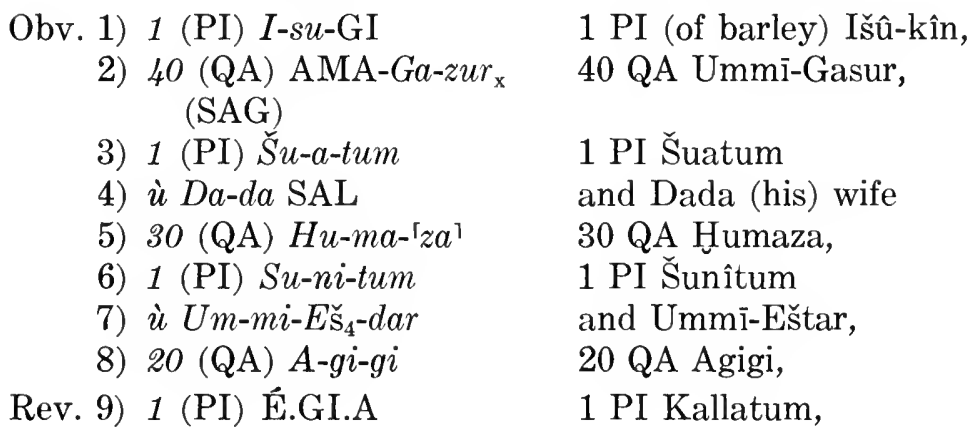

\section{Notes}

Line 2.- Interesting is the name AMA-Ga-SAG, that is, UmmiGasur, "the city of Gasur is my mother." The writing with the sign SAG, not SAG.GUNU, corresponds with the unique example in Meek, HSS X 57:8. (See also the writing GI for $\mathrm{GI}_{4}$, discussed below under line 9.) Gasur is the well-known city from which have come so many important tablets of the Old Akkadian period, published by Meek in the above-mentioned book. See also above, page 171, and, on the reading Gasur, J. Lewy in Journal of the American Oriental Society LVIII (1938) 458f. For the cities conceived as fem. beings see the discussion by J. J. Stamm in MVAG XLIV (1939) 92.

Line 3.-With our name $\check{S} u$-a-tum ef. the name Šuattu (various spellings); see Tallqvist, Neubabylonisches Namenbuch p. 203.

Line 4.-For SAL, "wife," in Old Akkadian instead of the usual DAM, cf. SAL EN-li in Meek, HSS X 153 viii 6 , in which, contrary to Meek, op. cit. p. xv, n. 33, SAL does not have to be taken as an error for DAM.

Line 5.-The sign $z a$ in Hu-ma-za is clear neither in this text nor in no. 14:4. It can be safely reconstructed on the basis of 


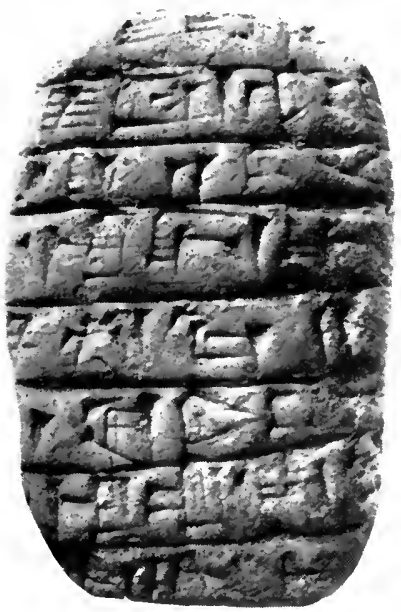

Obverse

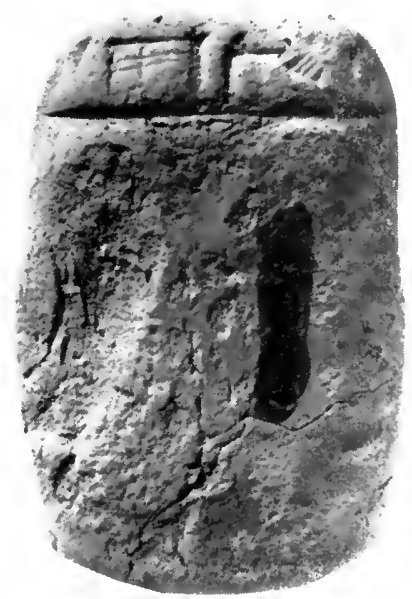

Reverse

TABLET $20($ FM 229210)

comparison with $H u-m a-z a$ on the Old Akkadian tablet from Tell Asmar published in $M A D$ I 30 iii 23.

Line 9.-The personal name É.GI.A is always written É.GI ${ }_{4}$ A in other Old Akkadian tablets (MAD I p. 194). Since E. $\mathrm{GI}_{4} \cdot \mathrm{A}$ is the Sumerian logogram for kallatum, "bride," really "daughter-inlaw," we may assume that our É.GI.A also represents kallatum. The omission of GUNU in this sign is paralleled by the omission of GUNU in the sign ZUR in $_{\mathrm{x}}$ the name AMA-Ga-SAG, discussed above. A personal name Gal-la-tim in the gen. occurs in Scheil and Legrain, Mém. XIV 7 rev. 3. 


\section{1 (FM 229208)}

The text deals with quantities of flour given by an unnamed person to Šunitum to be distributed as follows: 1 QA for the barber, 1 QA for a person named Kaspüša, and $1 \mathrm{QA}$ for a mare. The possibilities are that both ŠU.I and ANŠE.LIBIR.SAL are personal names. For the former, cf. Thureau-Dangin, ITT I p. 23, 1336 and n. 2; for the latter, cf. the "names" ANŠE.BAR.AN and ANŠE. BAR.AN.ARAD in $M A D$ I p. 180.

Interesting is the personal touch lent to the document by the writing $a-t i-n a$, "which I gave." No. 35:11 is similar in this respect.

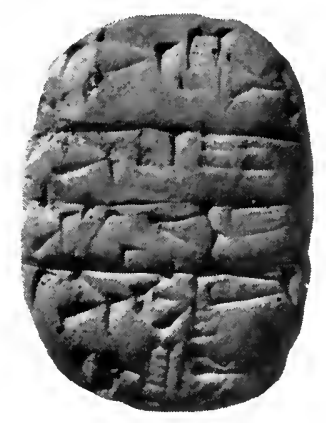

Obverse

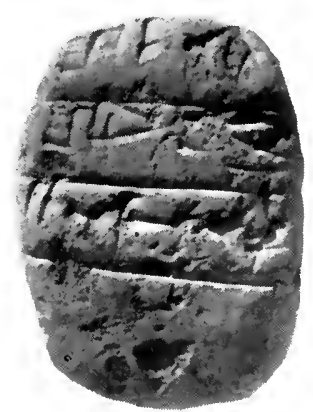

Reverse

TABLET 21 (FM 229208)

Transliteration and Translation

Obv. 1) ґ3’ QA ZÍD.GU

2) 1 QA ŠU.I

(Of the) '31 QA of GU-flour,

3) 1 QA KUG.BABBAR-sa 1 QA (for) Kaspūša,

4) 1 QA ANŠE.LIBIR.SAL $1 \mathrm{QA}$ (for) the mare,

Rev. 5) $\check{u} u a-n a$

6) $\check{S} u-n i$-tum

is that which to

7) $a-t i-n a$

Šunîtum

I gave.

\section{NOTES}

Line 1.-The logogram ZÍD.GU is translated as "e. feineres Gerstenmehl” by Deimel, ŠL II 536:296, following Hrozný, Das Getreide im alten Babylonien I (Wien, 1913) 200, a translation for which I can find no clear evidence. 
Line 3.-With our name KUG.BABBAR-sa cf. Gas-bu-ša, "her money," discussed by Stamm, MVAG XLIV 301f., and the note on $A$-ha-KUG.BABBAR-sa in no. 28:7.

Line 4.-The logogram ANŠE.LIBIR with the Sumerian reading DUSÚ and Akkadian equivalent agalu is translated by B. Meissner, $A S$ no. 4, pp. 2f., and idem, Studien zur assyrischen Lexikographie III ("Mitteilungen der Altorientalischen Gesellschaft" XI 1/2 [1937]) pp. 3f., as "Maulesel," English "hinny," that is, an animal resulting from the union of a stallion and a she-ass. G. Meier in $Z A$ XLV (1939) 201 and 211 translates the word in question as "Maulesel" and defines it as "Reitesel."

Certain points can be brought to bear against the interpretation of ANŠE.LIBIR as "hinny." The word occurs frequently in texts of the Old Akkadian period, and if it actually means "hinny" we should expect to find both horses and donkeys mentioned in the texts. But while donkeys are known from the texts, horses (ANŠE.KUR. $\mathrm{RA}$ ) are never mentioned in the written documents of that period. Furthermore, in our tablet we find a female ANŠE.LIBIR, in other tablets male ANŠE.LIBIR, as in the MAD I 288:1, Meek, HSS X 202 i 7, etc. Even more indicative are cases in which ANŠE.LIBIR. AMA, that is, mother-animals, are mentioned, as in the unpublished Oriental Institute text A 3012 and elsewhere. This distinction between female and male ANŠE.LIBIR in the texts shows that neither mule nor hinny could be meant. Since, normally, mules and hinnies, male or female, are not used for reproduction, there seems to be no reason for defining their sexes in the texts.

Landsberger in ZA XLI (1933) 224f. and in AOF X $(1935 / 36)$ 159 n. 82 translates the word in question as "onager" ("wild ass"). This is the Equus onager hemippus Lydekker, discussed fully by Max Hilzheimer, Animal Remains from Tell Asmar ("Studies in Ancient Oriental Civilization," no. 20 [Chicago, 1941]) pp. 2-20. Many skeletal remains of this onager were found at Tell Asmar (ibid.pp. 47f.). According to Hilzheimer, "these remains belong to animals undergoing change of teeth or to animals in the prime of life. This would indicate that the remains are those of wild animals taken in chase and brought to Tell Asmar to serve as food; for one utilizes tame horses or asses as long as possible, and in no case does one slaughter them in the prime of life except for sacrifice" (ibid. pp. 19f.). It may also be added that these animals - as in modern times-may have been slaughtered for food. The excellence of 
their meat was recognized in ancient as well as in modern times (ibid.pp. 2f.).

By way of supplemental commentary to the preceding we may note the information about the ANŠE.LIBIR-animal which can be gathered from several Old Akkadian tablets outside our collection. A number of animals defined as ANŠE.LIBIR.US̆, ANŠE.LIBIR. SAL, ANŠE.LIBIR.UŠ.AMAR, and ANŠE.LIBIR.SAL.AMAR, ranging from one to four years in age, are distributed to several persons (MAD I 6 and 8). Oxen (GUD) and ANŠE.LIBIR.UŠ together with their plows (MAD I 47) or oxen and SAL.ANŠE. LIBIR together with their plows (MAD I 136) are similarly given to various persons. ANŠE.LIBIR.UŠ together with wagons and plows occur also in Meek, HSS X 202 and 206. The textual evidence shows definitely that the ANŠE.LIBIR was a tamed animal and that it was used to draw wagons and plows. It is to be noted that the draft animals found on the Ur Standard and on other contemporaneous artistic representations were defined by Sir C. L. Woolley, Ur Excavations, vol. II, The Royal Cemetery, Text (London, 1934) pp. 271ff., as wild asses.

The difficulty, alluded to by Hilzheimer, op. cit. p. 20, that onagers cannot normally be tamed, does not seem insurmountable, since our knowledge of this animal is insufficient to allow of dogmatic conclusions. Hilzheimer himself takes into account the possibility that the Sumerians may have mastered the art of taming onagers, an accomplishment all the more remarkable because, so far as it is known to Hilzheimer, the onager has nowhere since been tamed on an extensive scale. But Meissner, Studien zur assyrischen Lexikographie III p. 4, referred to above, knows of a Persian custom of catching wild asses in wolf traps and of taming them in breeding farms. I do not know, however, whether the term "wild asses" refers to real onagers or to runaway domestic asses turned wild (such as are mentioned in Hilzheimer, op. cit. p. 2).

The third interpretation for ANŠE.LIBIR, that of "horse," was offered first tentatively by Thureau-Dangin in ITT I p. 2, later accepted by Deimel in $\breve{S} L$ II 208:48, and defended on archaeological and philological grounds by Hanns A. Potratz, Das Pferd in der Frühzeit (Rostock, 1938) pp. 32ff. If this interpretation is accepted it would mean that the old word for "horse," ANŠE.LIBIR agalu, was replaced in the course of time by another word, ANŠE.KUR. $\mathrm{Ra}$ sîsu. In comment to this interpretation it may be noted that since ANŠE.EDIN(.NA) sirrīmu is definitely "wild ass," the writing 
ANŠE.LIBIR should stand for an equid different from "wild ass," making thus plausible the interpretation of ANŠE.LIBIR as "horse" by the simple process of elimination.

In conclusion we should refer to one Sargonic text (MAD I 214), in which a number of ANŠE.LIBIR, distributed to various persons, are summed up as so many ANŠE, that is, "donkeys," and to two unpublished texts (A 3012 and A 3307), in which a number of ANŠE.LIBIR, ANŠE.BAR.AN, and ANŠE.EDIN are likewise summed up as so many ANŠE. Thus the ANŠE group of animals included according to these texts at least three different varieties of equids. More equids are listed in the text published in Barton, $P B S$ IX 1, no. 38 .

Line 5.-With the form $\check{s} u$ used as an accusative cf. $\breve{\mathrm{SE}} \check{s} u a-n a$ ŠE.BA $a$-si-tu, "the barley which as rations I had left over," in Meek, HSS X 5:4f., and our text no. 36:7.

Line 7.-On the very important occurrence of the subjunctive form $a$-ti-na see the discussion to no. 1:12. 


\section{2 (FM 229224)}

I am not certain that the interpretation offered below is the correct one. My understanding of the text is that Amat-Innin the barber gave Dada white barley, probably to be used as seed barley, for the estate.

\section{Transliteration and Translation}

$\begin{array}{ll}\text { Obv. 1) GEMÉ- }{ }^{\text {Innin }} & \text { Amat-Innin } \\ \text { 2) ŠU.I } & \text { the barber (gave) } \\ \text { 3) ŠE.BAR } . \mathrm{BAR}_{\mathrm{x}}(\mathrm{UD} . \mathrm{UD}) & \text { white barley } \\ \text { 4) } a \text {-na } D a-d a & \text { to Dada } \\ \text { 5) MÁS̆.PA.AL.TE } & \text { the . . . } \\ \text { 6) ŠE.NUMUN } & \text { Seed barley } \\ \text { Rev. 7) } \mathrm{E} & \text { of the estate }\end{array}$

\section{NoTES}

Line 1.-Professor A. L. Oppenheim points out to me the existence of fem. barbers (SAL.ŠU.I) in his Catalogue of the Cuneiform Tablets of the Wilberforce Eames Babylonian Collection ("American Oriental Series” XXXII [New Haven, Conn., 1948]) C 1 ii 12.

Line 3.-With ŠE.UD.UD in our text cf. ŠE.UD, translated as " "white' barley" by Gadd in Iraq VII 29 and 49f., as opposed to ŠE.SUMUN, “ “old' barley.” Also comparable is ÁS̆.UD.UD, translated as "white emmer" by Hrozný, Das Getreide im alten Babylonien I 72, besides ÁS̆.SI 4 , "red emmer," and KAŠS.UD.UD, "white beer," contrasted with KAŠ.MI, "black beer," in Thureau-Dangin, ITT I 1303 and 1378.

Line 5.-The interpretation of this line is difficult owing to the fact that only the first two signs, MÁS and PA, are clear. Then follow two signs which might be read as AL (hardly KAB) and TE. An interpretation of line 5 of our text as giving the profession of Dada, named in line 4, seems indicated.

Line 7.--After the sign $\hat{E}$ there is a hole in the tablet, but no trace of a sign is visible. 

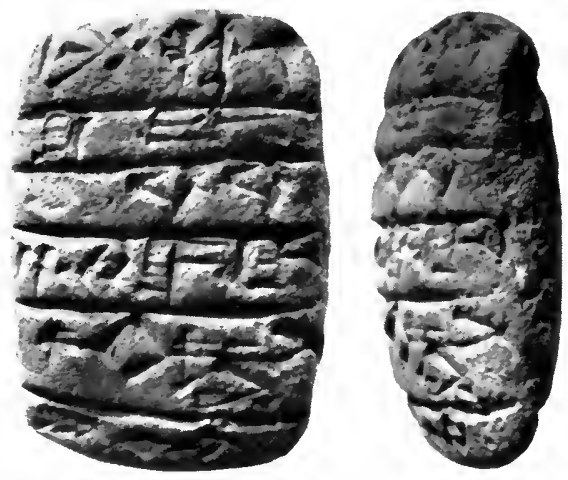

Obverse

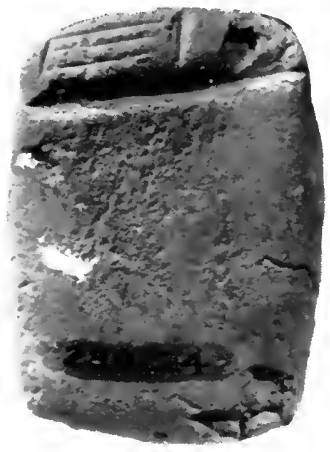

Reverse

TABLET 22 (FM 229224) 


\section{3 (FM 229236)}

From the standpoint of appearance, this is by far the worst tablet in the entire collection. It is clumsy in form, for it is much too thick in proportion to its size. The signs are badly incised, apparently with a blunt stylus and by an inexperienced hand. Also their forms are peculiarly, often carelessly, written. Several of the signs seem to have been inserted later.

The tablet deals perhaps with distribution of barley (lines 1-6) and reeds (lines $7-11$ ).

\section{Transliteration AND Translation}

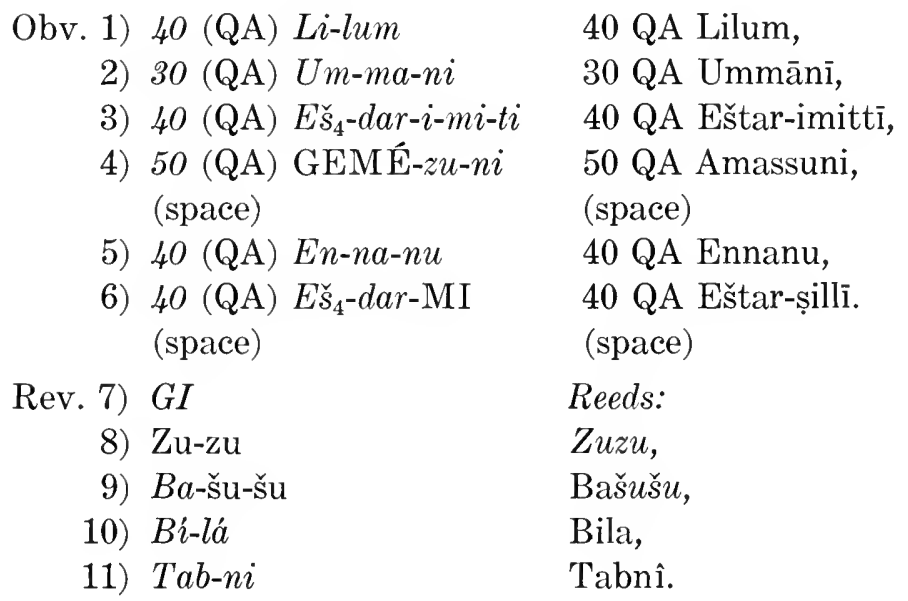

\section{NoTES}

Line 1.-For the personal name Li-lum ef. Thureau-Dangin, RTC 91 iii.

Line 7.- The sign looks more like ZI than GI; but since ZI gives no sense and GI, "reeds," occurs also on tablet no. 41:5, it seems plausible to assume that the error is due to the scribe's ignorance. 

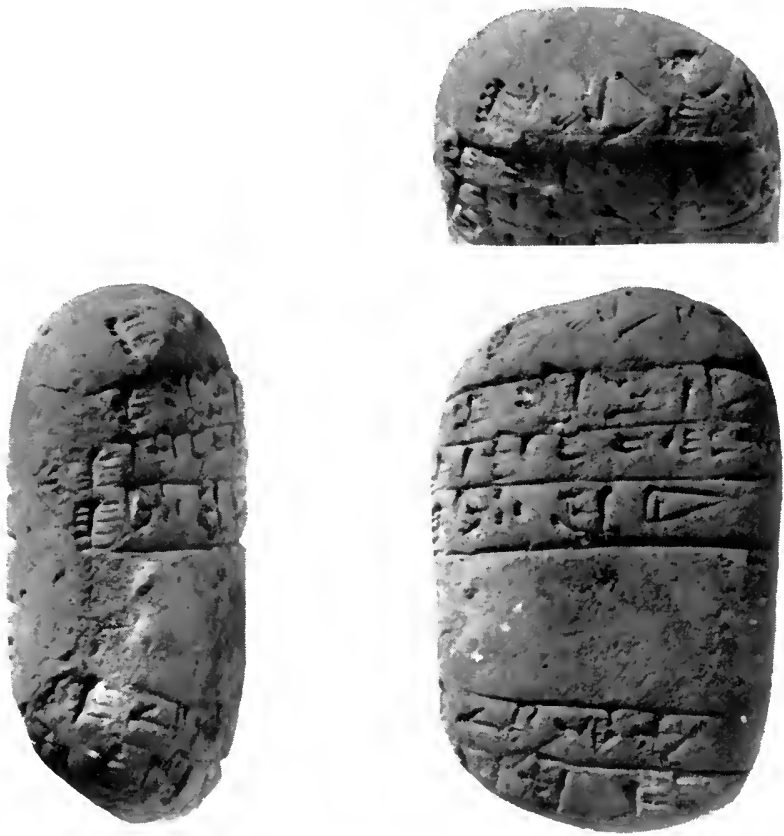

Obverse

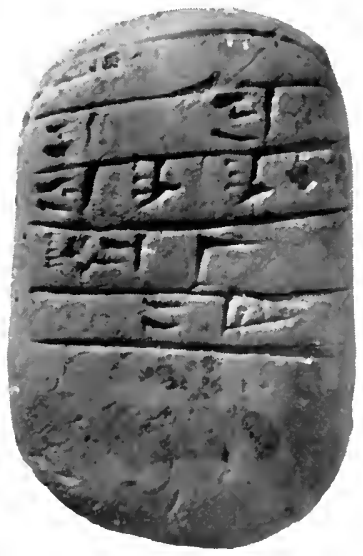

Reverse

TABLET 23 (FM 229236) 


\section{4 (FM 229242)}

Tablet very badly preserved. It seems to concern allotments of grain to various individuals.

\section{TRANSLITERATION}

(beginning destroyed)

Obv. $\mathrm{x}+1) 20(\mathrm{QA}) \ldots$

$\mathrm{x}+2) 20(\mathrm{QA}) B a-\mathrm{r}[\mathrm{i}-\mathrm{i}] \mathrm{s}-\mathrm{tum}$

$\mathrm{x}+3) 20(\mathrm{QA}) \check{s} u \check{s} a-m a-l[i-i] m$

$\mathrm{x}+4) 10(\mathrm{QA})$ La-ma-as-tum

(rest destroyed or unreadable) 

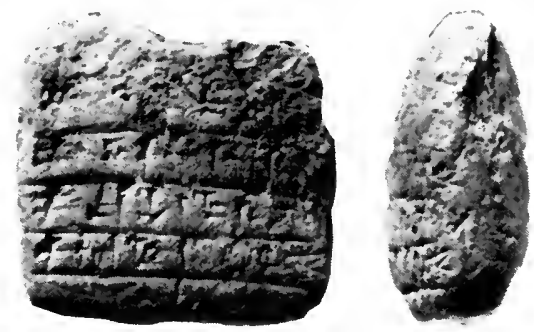

Obverse

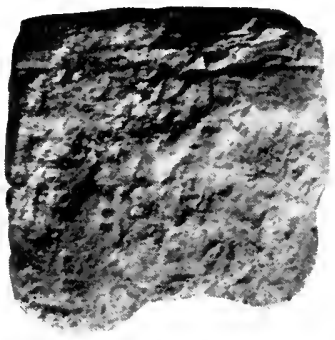

Reverse

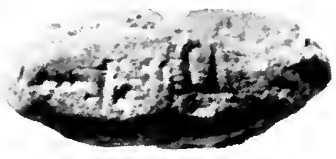

Left Edge

TABLET 24 (FM 229242) 


\section{5 (FM 229231)}

Lines 1-4 contain the linear measurements of a certain field. The personal names in these lines evidently refer to persons whose estates adjoined the northern, southern, eastern and western boundaries of the field in question. In line 5 the area of the field is stated to be $15 \mathrm{GA} N$. Although the text is damaged in front of the figure, it is certain that the figure should be no higher, for an area of 15 GÁN is already somewhat greater than the area of the field as calculated on the basis of the linear measurements given in lines 1-4.

Since 1 GÁN corresponds to 3528.36 square meters, 15 GÁN would be 52925.4 square meters, or about 3 acres. My figure for the size of the field is 54315 square meters.

The terms IM.MIR, "north," IM.U ${ }_{5}$, "south," IM.KUR, "east," and IM.MARTU, "west," in this text and -in a different sequencein no. 26 are those normally used for the cardinal points of the compass in the Old Akkadian period. Cf. Scheil, Mém. II p. 12, and elsewhere, for Susa; Hilprecht, BE I pls. VIff., for Sippar; ThureauDangin, ITT I 1406, for Lagaš; MAD I 176 and 336 for the Diyala River region; and Meek, HSS X 13, 16, and passim, for the Gasur region.

TRANSLITERATION

Obv. 1) 4 ÉŠ.GÍD 16 GI IM.MIR KA-Ma-ma MAŠ.MAŠ

2) 3 ÉŠG.GÍD $151 / 2$ GI IM.U. ${ }_{5}$ EZEN

3) 3 ÉŠ.GÍD LAL 2 GI IM.KUR $\bar{A}-r u-k u m$

4) 4 ÉŠ.GÍD $51 \frac{2}{2}$ GI I[M.MA]R.TU šu MUŠ.[. . . ? A]l-lu-lu

5) $\left[\mathrm{A} . \mathrm{S} \mathrm{SA}(\mathrm{G})_{4} \cdot \mathrm{BI} 6\right]+{ }^{-} 6^{7}+3 \mathrm{GA} \mathrm{A}$ (space)

Rev. 6) $[\ldots]$. . .

7) $\check{u} u \mathrm{~K}[\mathrm{~A}]-b e-l i$

8) šu $Z i-b a$

9) in $m[i]$-ih-ri URU-Gi-tim 


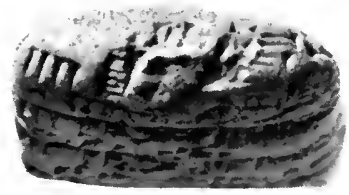

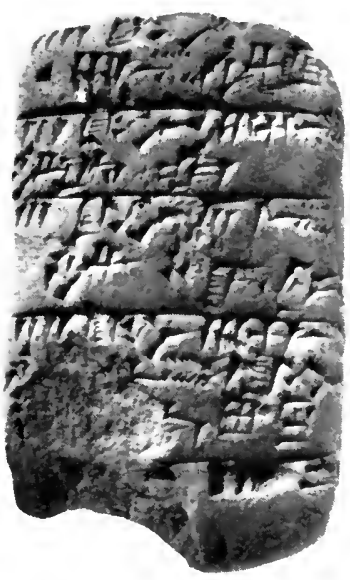

Obverse

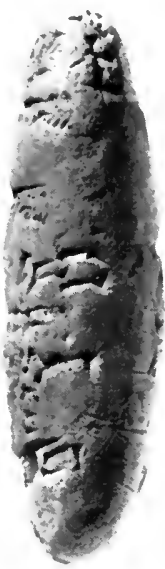

TABLET 25 (FM 229231)

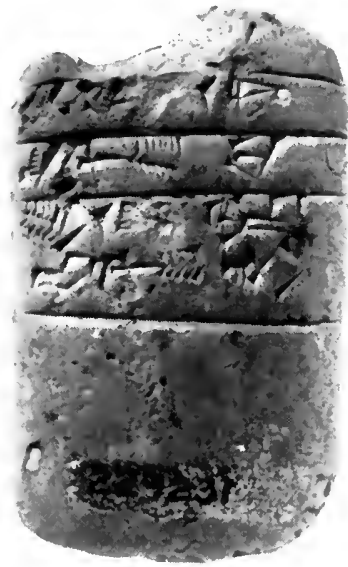

Reverse

\section{TRANSLATION}

Obv. 1) 4 ÉŠ.GÍD 16 GI, north, Pu-Mama the incantation priest;

2) 3 ÉŠ.GÍD $151 / 2$ GI, south, EZEN;

3) 3 ÉŠ.GÍD minus 2 GI, east, Arūqum;

4) 4 ÉŠ.GÍD $5 \frac{1}{2}$ GI, west, ... . of Allulu.

5) [Its area (is) 1$] 5 \mathrm{GÁN}$.

(space)

Rev. 6) [Field]

7) of Pu-bêlì

8) Of Ziba

9) in front of the city Kite. 


\section{Notes}

Lines 1-4. - The measure ÉS̆.GÍD is known to me only from this text, from no. 26 in our collection, and from an Old Akkadian tablet, $M A D$ I 176 . It may correspond to the ÉS found on later tablets. Note that both ÉŠ.GID and ÉS are linear measures of the next order above GI.

Line 2.-Dr. Jacobsen suggests comparison of EZEN with $\grave{I}-z i-n a$ (nos. 15:3 and 19:14) and interpretation of both as Isinna. The $-a$ ending found frequently in personal names of the Old Akkadian period (see, for example, $D u$-ma-ga under no. 50:1 and $D u b$-si-ga under no. 3:2, as well as [D]ar-su-ba, E-nam-ra, Ku-ru-ba, Si-w[i]-ra, Ti-ni-na in Index) and in common nouns (GU.ZI.DA, etc. discussed under no. 7:3) will be treated in a future publication. Cf. also $I$-zi-num in Thureau-Dangin, SAKI p. 168, no. 3; Meek, HSS X 186:2; $M A D$ I p. 210.

Line 3.-With the personal name Á-ru-kum cf. $A-r u-k i$ in gen. in Clay, $P N C P$ p. 59.

Line 4.- Instead of an expected personal name this line contains further information about the field, apparently to the effect that the western boundary of the field touched upon the land or structure belonging to a person named [A]llulu. Reconstruction to $[A] l-l u-l u$ is suggested by the occurrence of the personal name $A l-l u$-lu on the Maništušu Obelisk; see Scheil, Mém. II p. 41.

Line 9.-The phrase in m[i]-ih-ri URU-gi-tim is difficult to interpret. It may mean "as equivalent of the rigitum" or "opposite of the rigitum." The spelling ri-gi-tim suggests a feminine noun from the root $\mathrm{RG} / \mathrm{K} / \mathrm{Q}^{3}$. The only noun which $\mathrm{I}$ know to be based on this root is riqitum, representing some internal part of the body; the word is frequently encountered in religious literature and New Babylonian texts. But how could it possibly fit into our context? Should we read perhaps URU-Gi-tim and compare this place name with $K i-d e^{\mathrm{KI}}$ or $K i-t i^{\mathrm{KI}}$ discussed under no. $33: 50$ ? The latter suggestion is confirmed by the occurrence of URU-Ki-d $\grave{e}^{\mathrm{KI}}$ in geographic lists recently published by Selim J. Levy in Sumer III (1947) p. 52, no. 61 , where the name is misread as úru-DI-NE. 


\section{6 (FM 229249)}

Lines 1-4 give the measurements of the four sides of a field. The purpose of the additional measurements in lines $5 \mathrm{f}$. is not clear.

Unfortunately line 7, containing the area of the field, is only partially preserved. This line is inscribed upside down; no. 42 presents the same anomaly.

\section{Transliteration}

Obv. 1) $[x]$ GUD 2 ÉŠ.GÍD 3 GI [I]M.MAR.TU

2) $[x$ GUD $x]+1$ ÉS̆.GÍD 1 GI $[\mathrm{I}] \mathrm{M} . \mathrm{KUR}$

3) 1 GUD 1 ÉS̆.GÍD IM.U

4) 1 GUD 2 ÉŠ.GÍD $[x]+1$ GI IM.[MIR]

5) $1 \frac{1}{2}\left[\right.$ ÉŠ.GÍD IM].U $U_{5}$

6) 3 ÉŠ́.GÍD 1 GI IM.MAR.T[U] (space)

Rev. 7) $[x]+1$ GÁN $20 \mathrm{SAR}$

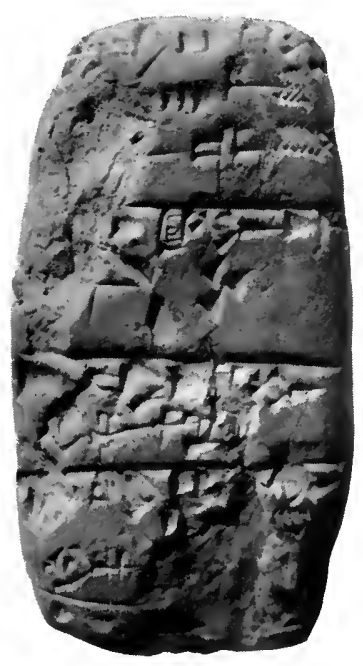

Obverse

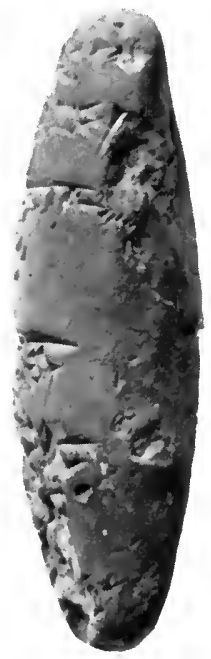

TABLET 26 (FM 229249)

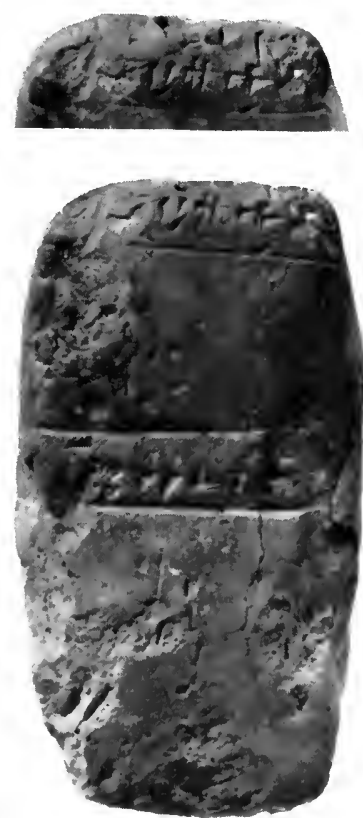

Reverse 
Translation

Obv. 1) [x] GUD 2 ÉŠ.GÍD 3 GI, west;

2) $[\mathrm{x}$ GUD $\mathrm{x}]+1$ ÉŠ.GÍD 1 GI, east;

3) 1 GUD 1 ÉS.G.GID, south;

4) 1 GUD 2 ÉŠ.GÍD $[\mathrm{x}]+1$ GI, no[rth];

5) $11 / 2$ [ÉŠ.GÍD, so]uth;

6) 3 ÉŠ.GÍD $1 \mathrm{GI}$, west. (space)

Rev. 7) $[\mathrm{x}]+1$ GÁN 20 SAR.

\section{Notes}

Lines 1ff.- It is possible that the measure GUD, for which I can find no parallels, corresponds to UŠ, but this is not sure. In favor of this supposition it may be noted that US is the linear measure of the next order above ÉS̆ (here and in no. 25 written ÉŠ.GÍD).

Line 3.- Note the writing $\mathrm{HU}$ with inscribed SI as against SI.HU in line 5 and in no. 25:2. 


\section{7 (FM 229218)}

Seven persons are "given," for an unspecified purpose, to the priest of the local temple. Perhaps they are workers hired by the priest to perform certain services. Cf. also the note on no. 28 .

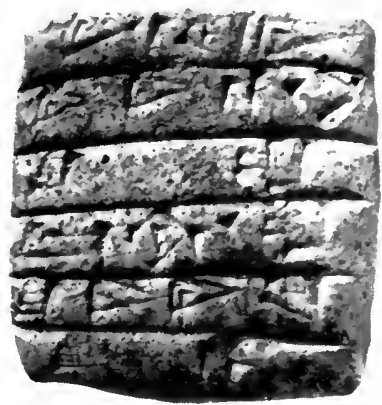

Obverse

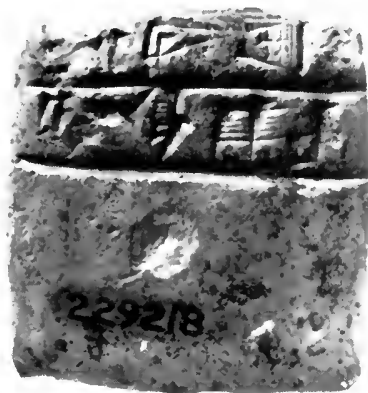

Reverse

TABLET 27 (FM 229218)

TRANSLITERATION

Obv. 1) ARÁD-zu-ni

2) $\grave{I}-l i-a-h i$

3) $\grave{S} u-u m$

4) $I p-t e-u-u m$

5) $\check{S} u-i-l i-s u$

6) $U \dot{U}-a$

Rev. 7) Hu-ni-zu

8) $a$-na SANGA 


\section{8 (FM 229219)}

A list of names of nine persons, similar in form to no. 27, but even more abbreviated; not only the purpose of the memorandum, but also the name or the title of the person to whom these nine persons are presumably being "given" is onitted.

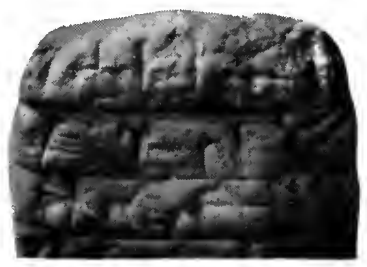

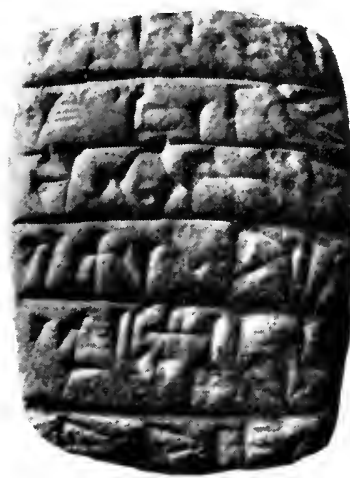

Obverse
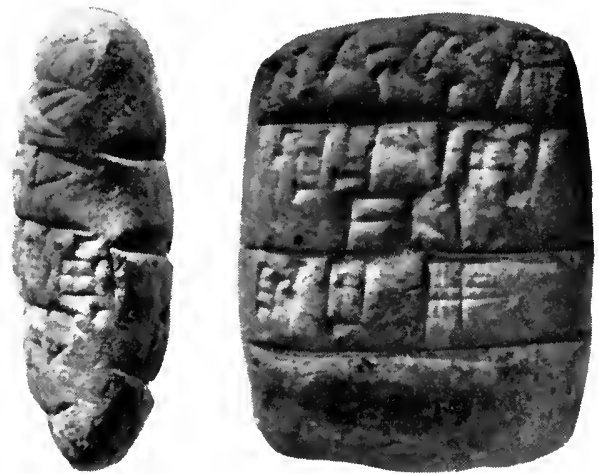

Reverse

TABLET 28 (FM 229219)

TRANSLITERATION

Obv. 1) $E \check{s}_{4}-d a r-\ldots$.

2) Āš-ma-tum

3) DINGIR-na-zi-ir

4) A-hu-li-bur-ra

5) $E \check{s}_{4}-d a r-d a m-g a-a t$

6) $\bar{I}-l i ́-d a n$

Rev. 7) A-ha-KUG.BABBAR-sa

8) $L a-\dot{a}-r a-a b$

9) $E-l u-s a$ 


\section{Notes}

Line 4.-The name $A$-hu-li-bur-ra lacks mimation, on which see the remarks on no. 49:12, and it can be compared with Li-bur-ri-im (in gen.) in our no. 30:5. Because of the spelling Li-bur-ra-am in Old Babylonian texts, Stamm, MVAG XLIV 155, n. 4, rejected the traditional derivation of this and other such names from the verb abārum, "to be strong," and proposed instead bârum, "to be clear, bright." In favor of this interpretation Stamm offered no convincing evidence. In my opinion, the writing with double consonants in these names as well as in many others, such as $U$-bar-rum for Ubārum, ${ }^{\mathrm{d}} \operatorname{Sin}$-i-din-nam for Sin-iddinam, is of no consequence as long as no such spellings as $* U$-ba-ar-rum or ${ }^{* d} \operatorname{Sin}$-i-di-in-nam are found. In other words, we may establish a rule that double writing expressed by means of a three-letter syllabic sign plus either a three-letter or a two-letter syllabic sign and conflicting with grammar can normally be disregarded. We may, if we choose, try to transliterate such spellings as $U-b a(r)-r u m,{ }^{\mathrm{d}} \operatorname{Sin}-i-d i(n)-n a m$, etc. Since the spellings $-l i-b u(r)-r a$ and $L i$-bu(r)-ri-im permit the interpretation as abārum or bârum we must try to find the right interpretation through other considerations. Our choice is against $a b \bar{a} r u m$, since this word is poorly attested in Akkadian, and in favor of buärum, "to be (firm)," parallel to kuānum in Old and Middle Assyrian, both in qal and in picel.

Line 7 .- Since the reading $A$-ha-KUG.BABBAR-sa does not seem to yield a good meaning we may have to consider the possibility of interpreting lines 6f. as Ilī-dan brother of Kaspūša. For the latter name see no. 21:3.

Line 8.-The personal name $L a-\dot{a}-r a-a b$ evidently corresponds to $L a-\grave{a}-r a-a b$, found frequently in the Old Akkadian tablets from Tell Asmar quoted in $M A D$ I p. 211. 
29 (FM 229235)

Since the complete inscription contains only the names of two individuals together with the names of their fathers, the purpose of this short memorandum must remain unknown. Interesting are the names Gal-pum=Kalbum, "dog," and Šubarijum, "Subarian," father of Gal-pum. "Subarian" as a personal name appears quite frequently in the published and unpublished tablets of the period. See on these occurrences the index to my $A S$ no. 22. A personal name Kalbu occurs also in Gelb, Purves, and MacRae, OIP LVII; cf. also the spelling 1 gal-pum UD.KA.BAR, "1 dog of bronze," in Luckenbill, OIP XIV 103:9. 


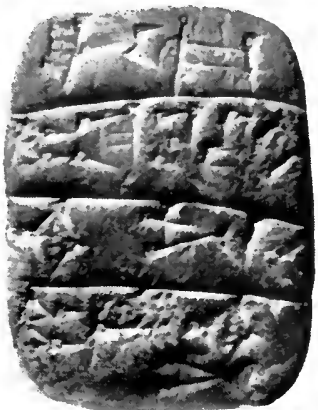

Obverse

TABLET 29 (FM 229235)

\section{Transliteration and TRANSLATION}

Obv. 1) Gal-pum

2) DUMU Su-ba-ri-im

3) Na-num

4) DUMU Zi-na-num

Rev. (uninscribed)
Kalbum

son of Šubarijum, Nanum son of Zinanum. 


\section{0 (FM 229228)}

A list of eight persons, of whom two are designated as ŠE ̌.SAL and three are designated as $k u-l u-\grave{u}$ at the end of the inscription. The two appellatives are clearly connected with each other.

The two persons Izaza and Alili are designated as being the ŠES.SAL of other men. This appellative is known to me only from an Old Akkadian tablet published in Scheil, Mém. XXIV 342:7f., where we read $M a-m a$ ŠEŠ.SAL $\check{S} u m$-su, translated as "sister" by Scheil (and possibly from $M A D$ I 250 iii 22). The logogram SAL. ŠE for "sister," cited by P. Kraus, MVAG XXXVI 113, is most probably SAL.KU=NIN, as is normal in Old Babylonian. Inasmuch as no evidence is known to me for ŠEŠSAL or SAL.ŠE $\check{S}=$ ahâtu, "sister," we must search for another interpretation of this logogram. Possibly ŠE ̌̌S.SAL of our text is identical with SAL.ŠE ̌ having the Sumerian reading SIŠ and Akkadian equivalent sik-ri-tu in the syllabary Rm 2, 26:9, published by Meissner, Supplement zu den assyrischen Wörterbüchern (Leiden, 1898), Autographien, pl. 24. This difficult word was first translated as "weibliche Männer" (root ZKR) by Landsberger in Zeitschrift der Deutschen Morgenländischen Gesellschaft LXIX (1915) 519ff.; later he abandoned this interpretation and in $A O F$ X 145 was inclined to follow the translation "Abgesperrte"= "Haremsfrauen" (root SKR) proposed by Ungnad in $Z A$ XXXVIII (1929) 194. G. R. Driver and Sir John C. Miles, in a study entitled “The SAL-ZIKRUM 'Woman-Man' in Old Babylonian Texts," Iraq VI (1939) 66-70, proposed the translation "eunuch" or "epicene" for SAL-ZIKRUM and differentiated it from "zikrîtu or "figrî/êti, which they translate as "enclosed woman."

The appellative $k u-l u-\grave{u}$, applied to three persons listed at the end of the inscription, should correspond to the word kulu'um, discussed by Meissner in AOTU I 1 (1916) p. 50 and translated by him as "male prostitute," "lover."

\section{TRANSLITERATION}

Obv. 1) 1 A-ti-e

2) [1] $E \check{s}_{4}-d a r-d a m-g a-a t$

3) [1] $E \check{s}_{4}$-dar-ra-bi-at

4) $1 \dot{I}-z a-z a$

5) ŠEŠ.SAL Li-bur-ri-im

6) 1 A-li-li

7) ŠE Š.SAL $A$-bí-bi 
Rev. (space)

8) 1 Sá-lim-me-ni

9) $1 E \check{s}_{4}-d a r-d u-[g u] l-t i$

10) $1 R i-i^{\top}$-tum

11) $k u-l u-\grave{u}$

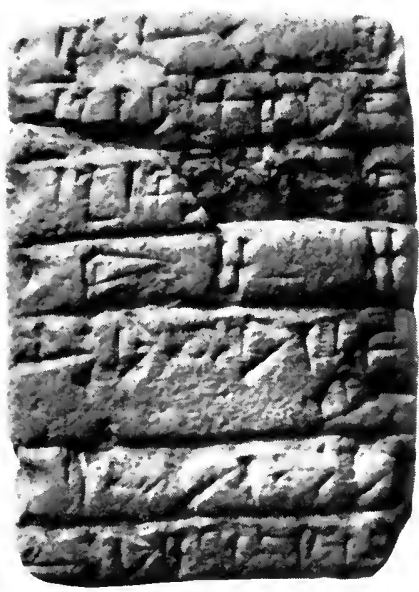

Obverse
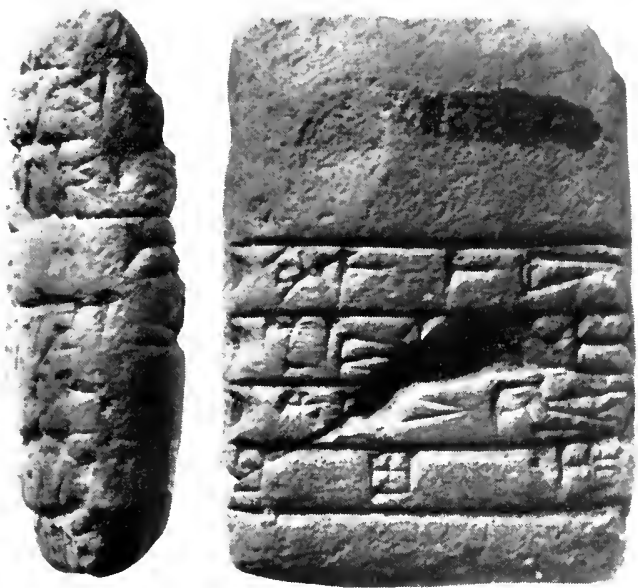

Reverse

TABLET 30 (FM 229228)

\section{NoTES}

Line 4. - The reading of $N i-z a-z a$ as $\grave{I}-z a-z a$ is based on comparison with the spelling $I-z a-z a$ in T. Fish, Catalogue of Sumerian Tablets in the John Rylands Library (Manchester, 1932) 5:5, Mém. XVIII 180 ii 7 and 12, and XXVIII 404:18.

Line 5.-The genitive form Li-bur-ri-im as compared with the nominative $L i$-pù-ru-um, in no. 49:6 shows that personal names could be declined in the Old Akkadian period. Such cases of declension are rare, however, since, with the exception of Li-bur-ri-im, [M]amá-tim (no. $51 \mathrm{x}+10$ ), and Su-ba-rí-im (no. 29:2), all other examples show lack of declension; cf. the names $D a$-bi-lum (no. 2:16), Dar-e-tum (no. 3:9), E-la-me-tum (no. 9:10), I-ni-um (no. 4:7), $\grave{E}$-[n]i-um (no. 7:30), Maš-tum (no. 3:6), $\check{S} u$-na-ak-pum (no. 9:8), and $Z i$-na-num (no. 29:4), all nominatives in form, genitives in syntax.

Line 10.-For the personal name $R i^{-}{ }^{-}{ }^{\top}{ }^{\top}-t u m=R \overline{\mathrm{e}}$ îtum see $\mathrm{n}$. to no. $6: 4$. 


\section{1 (FM 229234)}

The tablet first enumerates one donkey, one garden, and one house in Akkad and then ends abruptly with $L u$-ga-lu-mu-uk, which can hardly be anything other than a personal name. In spite of the fact that $\breve{u} u$ is normally singular (but cf. Meëk, HSS X 198:6), it seems to apply here not only to the house, but also to the donkey and the garden, that is, all three objects were in Akkad. But the relationship of these to Lugalumuk cannot be determined.

\section{Transliteration and Translation}
Obv. 1) 1 ANŠE.BAR.AN
1 BAR.AN-donkey,
2) 1 GIS̆.SAR
1 garden,
3) $\grave{u} 1 \mathrm{E}$ and 1 house
4) $\check{s} u A-g a-d \grave{e}^{\mathrm{KI}}$ of (in) Akkad
Rev. 5) Lu-ga-lu-mu-uk
(belonging to) Lugalumuk. 


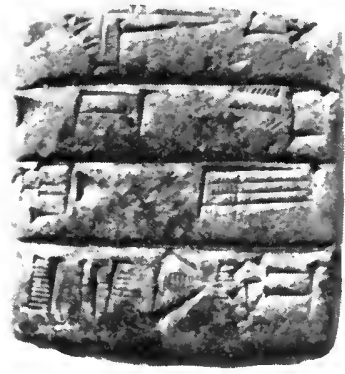

Obverse

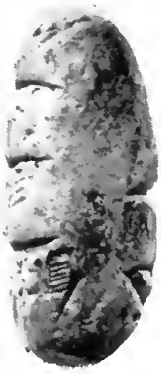

TABLET 31 (FM 229234)

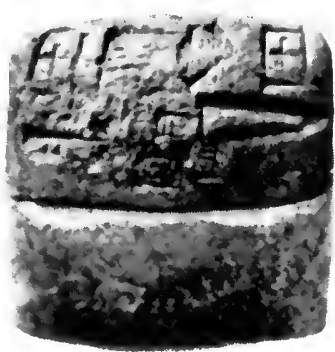

Reverse

\section{Notes}

Line 1.-ANŠE.BAR.AN occurs frequently in the older texts, but exactly what kind of donkey it denotes is as yet uncertain. For references see Deimel, $\breve{S} L$ II $74: 182$ and 208:24. It may be of importance in future identifications of this animal to note that ANŠE.BAR.AN.SAL and ANŠE.BAR.AN.AMAR.SAL are found distributed together with different classes of ANŠE.LIBIR to various persons in tablets of the Old Akkadian period, MAD I 6 and 8 (discussed above under no. 21:4).

Line 5.-Lu-ga-lu-mu-uk sounds like a Sumerian name composed of LUGAL plus an unknown element -umuk. The logogram ${ }^{L}$ U.MUG listed in the glossary to San Nicolò and Ungnad, Neubabylonische Rechts- und Verwaltungsurkunden I p. 153 (under šandanakku) and in Deimel, $\check{S} L$ II 411:146 is to be read as AS̆GAB. 


\section{2 (FM 229239)}

A well-preserved tablet recording the loan without interest of 1 female lamb to Kališ-țâb and the loan, evidently at a certain established rate of interest, of 4 PI of barley to Išaša.

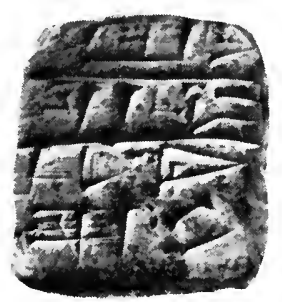

Obverse

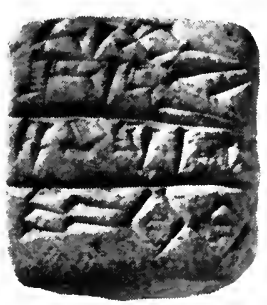

Reverse

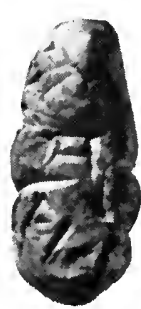

TABLET 32 (FM 229239)

Transliteration and Translation

Obv. 1) 1 SILA $_{4} \cdot$ SAL

2) $i \grave{s}-d \grave{e}$

3) $G a-l i-i \check{s}-\mathrm{DUUG}$

Rev. 4) hu-bu-da-tum

5) 4 (PI) ŠE $i s ̌-d \grave{e}$

6) $I$-sá-sá
1 female lamb

(is) with

Kališ-țâb, free of interest.

4 PI of barley (are) with Išaša.

\section{Note}

Lines 2 and 5.-On the reading and meaning of $i \check{s}$-dè, "with," "from," in Old Akkadian see Meek in RA XXXIV (1937) 63f. 


\section{3 (FM 229201)}

This is the largest tablet in the collection and the only one inscribed in four columns. The inscription is very well preserved and all the signs are relatively easy to decipher. More difficult is the interpretation of the inscription.

In lines 1-17 are enumerated provisions, trees, and objects of wood. Lines 18-43 contain identical or similar entries, most of which are accompanied by the names of persons for whom they may have been destined. Following a blank space on the tablet, lines 44-50 contain perhaps the names of the individuals who took care of the transportation and the names of the two places to which shipment was made. A separate shipment of provisions, implements, and trees seems to be described in lines 51-55. The last column of the tablet, comprising lines $56-62$, seems to list the persons to whom this shipment was made.

Lines $8-17,33 f$., and 36 exhibit a feature that is unique among the tablets of this collection, namely, the presence of checkmarks beside certain entries in the list. These ancient checkmarks, like our modern ones, are made in the form of an " $\times$," except that the strokes are made not from top to bottom but from left to right. Why certain items were thus checked and others not cannot be ascertained.

The custom of checking certain entries in a list is very old. Examples are to be found on some tablets of the Pre-Sargonic period, as in Nikolskii, Drevnosti Vostochnyi a ("Trudy vostochnoí kommissii imperatorskago Moskovskago arkheologicheskago obshchestva," vol. III, part 2 [St. Petersburg, 1908]) 41 and 52, and in Barton, PBS IX 1, no. 83. This custom is evidenced also in the later period, as in the Old Akkadian tablets $M A D$ I 86 and 232; in Thureau-Dangin, RTC 96; and in Meek, HSS X 51, 187, 188.

The names of the various plants mentioned in the inscription have been translated, following R. Campbell Thompson, A Dictionary of Assyrian Botany (London, 1949). The untranslated words are given in their Sumerian forms. 


\section{Transliteration and Translation}

Col. i

Obv. 1) 40 (QA) NINDA.

BAPPIR

2) 2 (PI) ZÍD.ŠE

3) 45 GIŠ̀.ÙR

4) 2 GIŠ.SINIG GAL

5) $2^{\mathrm{GIS}} a-z a-a n$

6) GIŠ 5 GIŠ.K[A]

7) 2 GIŠ.MAR

8) 2 (erasure) GIŠ. $\times \mathrm{DA}$

9) 2 GIŠ. $\mathrm{KID}_{5} \times$

10) 10 ŠU SU.SU $X$

11) 2 GÚ SU. $\times \mathrm{SU}$

12) 1 GIŠ.ŠE.Ù TUR $\times$

13) 1 na-ba $\times$ tum

14) 8 GÚ GIŠ.MA.NU $X$

15) 4 GIŠ.GÜ.ŠUBUR $\times$

16) $1 \times{ }^{\mathrm{GIS}}$ al-lum

17) 40 GIŠ.KA $k i-i \check{s} \times z a-b i$

18) [40 (QA) NINDA].

\section{BAPPIR}

(rest of col. i broken away; nothing or at most one line missing)

Col. ii

19) 2 (PI) ZÍD.ŠE

20) 40 GIŠ.ŠUBUR

21) Du-gul-tum

22) $20 d i r-k u-l i$

23) 30 GIŠ.ŠUBUR

24) $S u$-ni-tum

25) $40 \mathrm{ME}-K i$-dè

26) 40 A-ga-ga

27) $26 \mathrm{Ba}-\mathrm{lu}$-sa

28) 30 GIŠ $L a-w i$-ip-tum

29) $30 E \check{s}_{4}-d a r-d a-r i$

30) $15 \mathrm{~A}-\mathrm{li}-\mathrm{li}$

31) 80 si-na-at ki-iš-za!-bi

32) šu-ut Ib-ri-me

33) 2 GIŠ. $\times \mathrm{KID}_{5}$

34) $1 \times$ GIŠ.KA DUBBIN
40 QA of beer bread,

2 PI of barley flour,

45 beams,

2 large tamarisk trees,

2 myrtle trees, wood for 5 pegs,

2 wooden spades,

2 wooden boards,

2 wooden trays,

10 "hands" of door bands,

2 "necks" of door bands,

1 small ŠE.Ù-tree,

1 (part of a chariot),

8 talents of laurel sticks,

$4 \ldots$...

1 hoe,

40 pegs for threshing boards, [40 QA] of beer [bread], 
35) 1 ŠU SU.SU

36) 40 GIŠ $k i-i \check{s}-z a-b i \times$

37) 4 GIŠ.NAG.BAL
1 "hand" of a door band, 40 wooden (pegs) for threshing boards, 4 wooden .....,
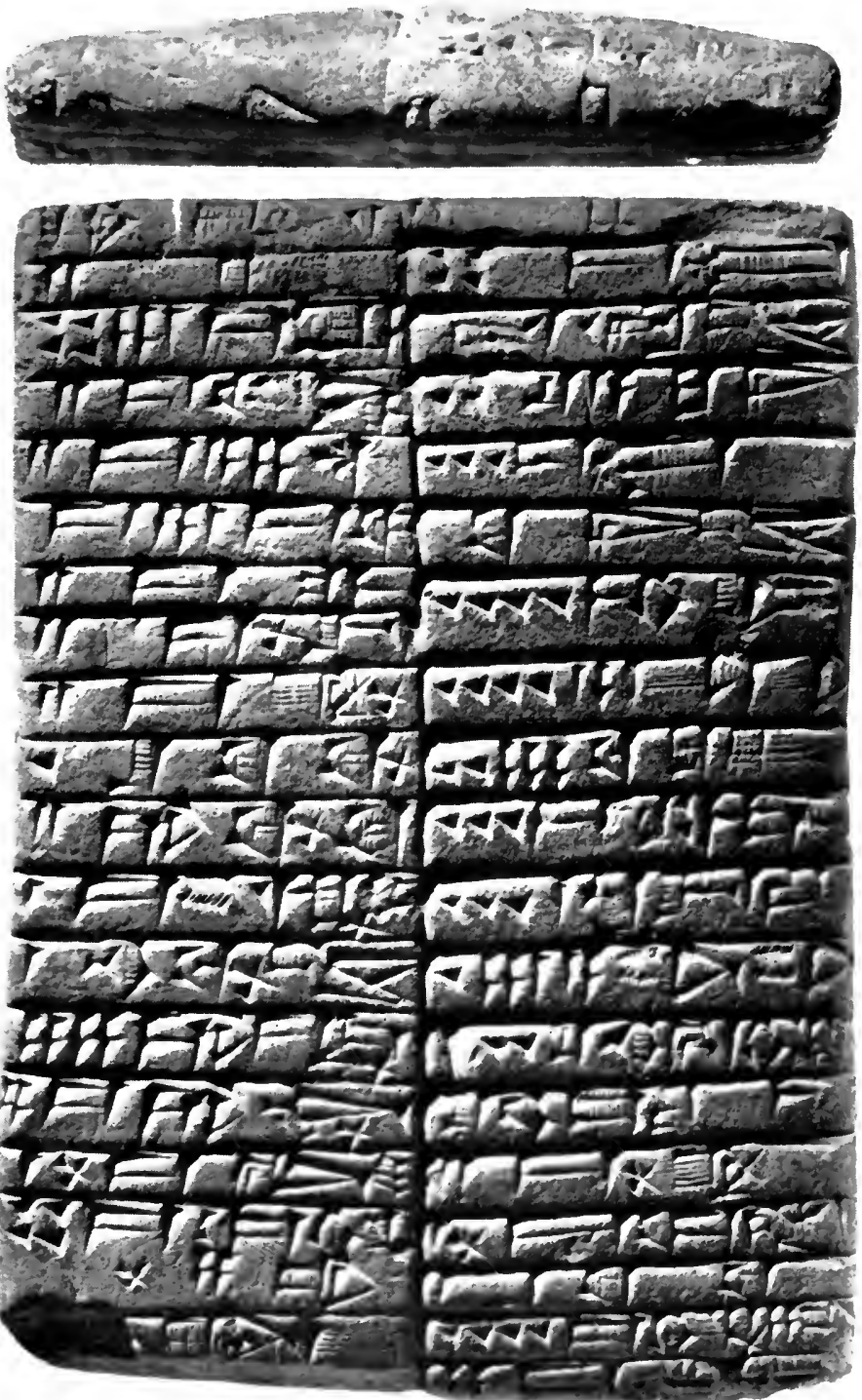

Obverse

TABLET 33 (FM 229201) 
Col. iii

Rev. 38) $30 E$-zé-zé [...]?

39) 2 GIŠ.KID $5 \check{S} u-u m$

40) $7 \mathrm{KID}_{5}{ }^{\mathrm{d}} \mathrm{UTU}-\mathrm{SA}$

41) 2 KUŠ.LAL.A.GÁ

42) GIŠ $e$-ni Ù.URU.A

43) 4 GIŠ.NISABA (space)

44) DINGIR-dan

45) $\breve{S} u-E \check{S}_{4}-d a r$

46) Zu-zu a-na Ban-ga ${ }^{\mathrm{KI}}$

47) Gu-gu TUR (double line)

48) Nin-líl-iš-gi-in

49) $N a-b i-u m$

50) in $K i-d e^{K \mathbf{I}}$ (double line)

51) ŠU.NIGÍN GÚ $E \check{s}_{4}$-dar-UR.SAG

52) $u$-bi-lam

53) 50 (QA) ZÍD.ŠE 1 GIŠ́.MAR
30 (trees) Ezeze,

2 wooden trays Šu ${ }^{\prime} u m$,

7 (wooden) trays Šamaš-bîtī,

2 sacks,

....,

4 soda plants

(space)

Ilum-dan,

Šu-Eštar,

Zuzu, to (the city of) Banga (brought it).

Gugu the Younger, (double line)

Ninliliš-kîn,

Nabi'um

(are) in (the city of) Kite.

(double line)

Total load (which) Eštarqarrād

brought:

50 QA of barley flour,

1 wooden spade,

54) 2 (PI) NINDA.BAPPIR 2 PI of beer bread, 4 beams, 4 GIŠ.ÙR

55) 50 GIŠ.ŠUBUR

1 NISABA

50 ŠUBUR-trees, 1 soda plant

Col. iv

(space)

56) $a-n a A-t i-t i$

57) $M a-a t-n a-h u-u m$

58) $S a-a-n i-i \check{s}$

59) $U m-m i-m i$

60) ù En-ni-lí

61) KUG.GI (space)

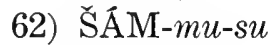

(space)

for Atiti, Matnahum,

Ša’aniš,

Ummimi, and Enn-ili.

Gold

(space)

(is) its price. 

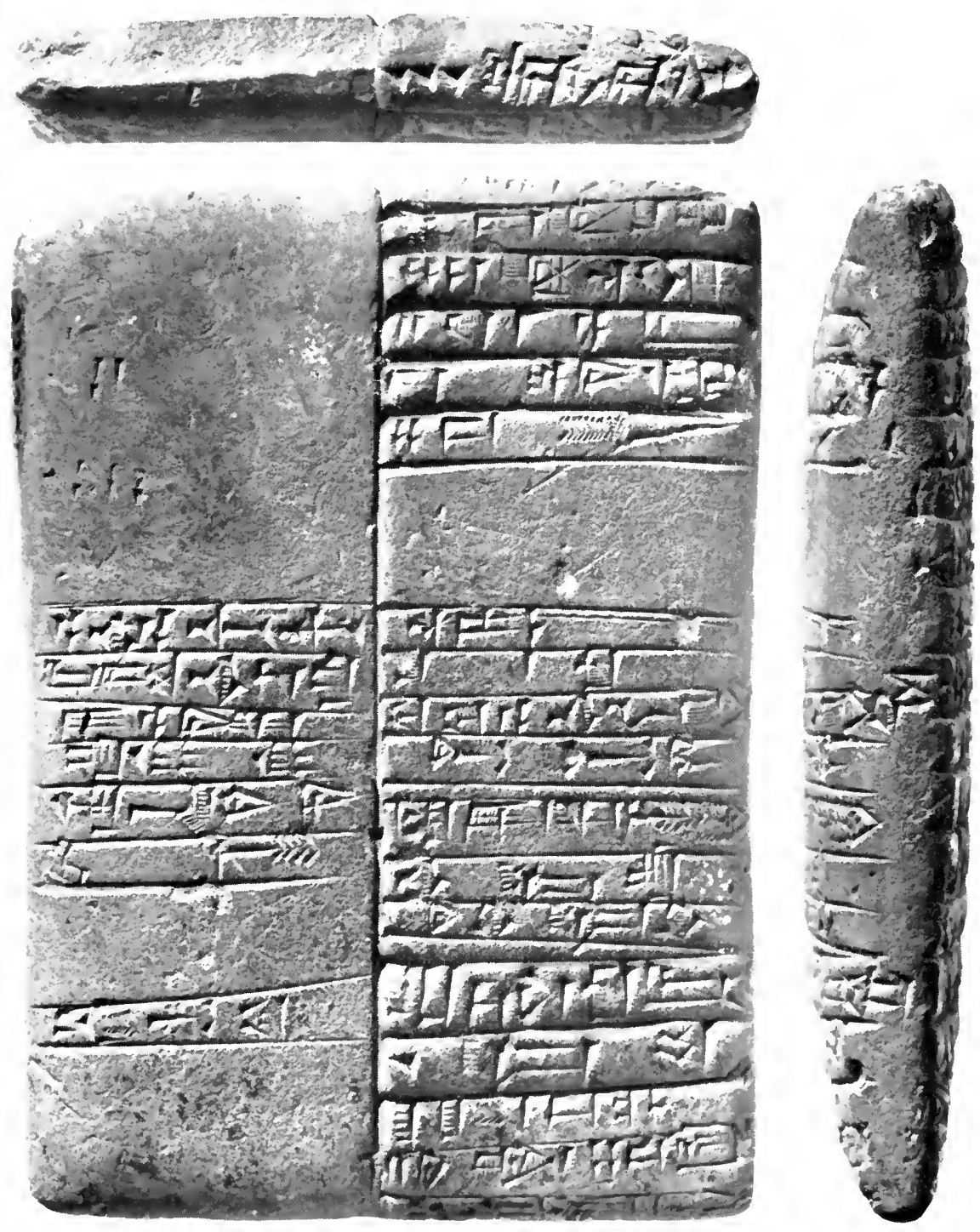

Reverse

TABLET 33 (FM 229201) 


\section{Notes}

Line 1.-BAPPIR here as well as in lines 18 and 54 is the wellknown ingredient used in making beer. According to numerous prescriptions of the Pre-Sargonic period beer was made from three main ingredients: (a) emmer or barley,, (b) KA $\breve{S}+\mathrm{GAR}$ (later S̆IM + GAR or BAPPIR), and (c) $\mathrm{MUN}_{\mathrm{x}}(\mathrm{BULUUG})$. Since $\mathrm{MUN}_{\mathrm{x}}$ is almost certainly "malt" (cf. Hrozný, Das Getreide im alten Babylonien I 154), it follows that BAPPIR cannot be "malt" as taken by some scholars. Since it is made into loaves of bread (NINDA) it cannot be a liquid as proposed by Poebel in $Z A$ XXXIX (1930) 156-60. The exact translation of BAPPIR is as yet unknown. The translation of NINDA.BAPPIR as "beer bread," here followed, is provisional and noncommittal. On the whole problem, besides Poebel and Hrozný, cited above, see mainly W. Förtsch in $O L Z$ XIX (1916) 101-5; H. F. Lutz, Viticulture and Brewing in the Ancient Orient (Leipzig, 1922); Deimel in Orientalia XXXII (1928) 57ff.; A. Götze in MVAG XXXII 1 (1928) 64-77; E. Huber in Reallexikon der Assyriologie II (1938) 25-28; idem, Bier und Bierbereitung bei den Völkern der Urzeit. I. Babylonien und Ägypten (Berlin, 1926) (unreliable from the linguistic point of view); L. F. Hartman and A. L. Oppenheim, On Beer and Brewing Techniques in Ancient Mesopotamia, Supplement to the Journal of the American Oriental Society no. 10 (1950).

Line 3.-The end of the sign ÜR here as well as in line 54 differs from the normal writing. From our text and from other similar texts of the same period (such as MAD I 272) we get the impression that GIŠ.ÙR represented a real tree. Perhaps the secondary meaning "beam" developed as a result of the fact that the wood of this tree was particularly suitable for making beams for the roof.

Lines $5 f$.-With $2^{\text {GIŠ }} a$-za-an GIŠ 5 GIŠ.K[A], "2 myrtle trees, wood for 5 pegs," in our text cf. GIŠ.ŠUBUR GIŠ $u$-rí-i $[m]$, "ŠUBUR-trees, wood for the roof," in no. 39:1f. On GIŠ.KA, "pegs," see note to line 17 .

Lines 10f.-The logogram SU+SU is used for the Akkadian $i a-\dot{u}$ (var.: $e-a$ ) and kurussu of a door (also of a plow); see Deimel, $\check{S} L$ II 7:39. The meaning of these words is difficult to determine because of their rare occurrence in the Akkadian sources. Perhaps they denote the leather bands or fastenings by means of which the doors were attached to the wall. See also W. Muss-Arnolt, Assyrischenglisch-deutsches Handwörterbuch (Berlin, 1905) pp. 439f. and Ungnad in $Z A$ XXXI (1917/18) 50f. 
ŠU, "hands," and GÚ, "necks," presumably denote certain parts of the door bands, depending on the position in which they were used, but closer identification is as yet impossible.

Line 12.-Our GIŠ. ̌́E.Ù (also in no. 43:17) is possibly the equivalent of GIŠ.ŠE.U.KU, the normal Sumerian logogram for "fir cone."

Line 13. - The word na-ba-tum may correspond to na-ba-du ša GIŠ.MAR, some part of a chariot, in a late syllabary published in $C T$ XII 15 rev. ii 22 (also Deimel, $\breve{S} L$ II $12: 2$ and 45). Cf. also na-pa-du, made of wood, in J. A. Knudtzon, Die El-Amarna-Tafeln I (Leipzig, 1915) no. 13:27, and 62 GIŠ na-ba-tum LAM in David W. Myhrman, BE III 77:3.

Line 14.- Cf. $x$ GÚ GIŠ.MA.NU in Thureau-Dangin, RTC 221 vi and 22 rev. ii.

Line 15.-The sign after GÚ is perhaps ŠUBUR; it differs slightly from the ŠUBUR sign in lines 20,23 , and 55 , but it resembles the sign in no. 39:1 (see p. 177). What GIŠ.GÚ.ŠUBUR is-if read correctly - it is hard to say.

Line 17.-Comparison of

40 GIŠ.KA $k i$-iš-za-bi in line 17 with 80 si-na-at $k i$-iš-za-bi in line 31 and 40 GIŠ $\quad k i-i \breve{s}-z a-b i$ in line 36

leads to the conclusion that the expressions GIŠ.KA, si-na-at, and GIŠ are more or less synonymous. Since KA is the normal Sumerian logogram for Akkadian šinnum, plur. šinnātum, "tooth," it seems quite simple to connect the first and second expressions. The third expression gives simply " 40 pieces of wood," or, perhaps better, "40 wooden (teeth)," of the type used on an implement called $k i-i \check{s}-z a-b i$, a form which can be analyzed grammatically only as the oblique case of the plural.

The exact meaning of the entire phrase becomes clear when we compare it with šin-ni kir-zap-pi in a late religious text, II $R$ 60:61a and $\mathrm{b}$. The first word is šinne in the oblique case of the plural, and its use is parallel to that of the form šinnātum (see Delitzsch, $A H W B$ p. 676b). The second word is kirzappum, which is usually translated as "footstool" in the existing Akkadian dictionaries.

One logogram for kirzappum is GIŠ.GİR.GUB (Deimel, $\breve{S} L$ II 444:46), which, as the individual signs in the logogram show, must mean "a wooden footstand." The other logogram is GIŠ.BAD (Deimel, $\breve{S} L$ II $69: 74=296: 33$ ), which is found also in the combination 
KA.GIŠ.BAD.DA, discussed by Landsberger, Die Serie ana ittišu (Roma, 1937) pp. 170f. According to him, GIŠ.BAD is an agricultural implement used in connection with threshing (in Akkadian "opening") of the grain; it has "teeth," and it is drawn by oxen. According to Landsberger this would suggest the meaning "threshing board" ("Dreschschlitten") for GIŠ.BAD. The Akkadian equivalent for GIŠ.BAD was unknown to Landsberger.

From the juxtaposition of $s i-n a$-at (var. GIŠ.KA) $k i-i s ̌-z a-b i$ in our text, šin-ni kir-zap-pi in Rawlinson, loc. cit., and KA.GIŠS. BAD.DA in Landsberger, loc. cit., it is obvious that the terms $k i-i s ̌-z a-b i$ and $k i r-z a p-p i$ are identical. The dissimilation of two contiguous sibilants into a liquid plus a sibilant in the example kišzappum > kirzappum can be observed also in Akkadian kussû > kursû, Syriac kursajā, Arabic kursijjun, "throne," "chair" (see Meissner in MVAG X 4 [1905] 272). Similarly, Hebrew KRSM developed from the picel form KSM, "to cut" (as suggested to me by the late Prof. S. I. Feigin of the Oriental Institute). On this problem see also C. Brockelmann, Grundriss der vergleichenden Grammatik der semitischen Sprachen I (Berlin, 1908) $243 \mathrm{ff}$.

The "teeth" mentioned in connection with kišzappum or kirzappum show clearly that this word cannot mean "footstool" in our texts, for it is hard to visualize the possible significance of "teeth" on a footstool. On the other hand, the term "teeth" is perfectly logical in connection with a threshing board. I myself have often seen "toothed" threshing boards in use in Turkey. The following description of threshing in the vicinity of Alishar in Turkey is taken from J. A. Morrison, A Unit of Land Occupance in the Kanak Su Basin of Central Anatolia (dissertation at the University of Chicago [Chicago, 1939]) p. 39:

Threshing is accomplished with the threshing sled-the deven, which, in size and shape, resembles the New England "stoneboat"... It consists of a plank approximately one and one-half meters long and sixty centimeters in width, slightly turned up at one end, and its under side studded with sharp flints....

As soon as a stack of unthreshed grain has been piled as high as it conveniently can be, threshing begins. Enough is pulled off the top of the stack to form a loose layer about forty centimeters thick around its base and extending outward from it some three or four meters. Over this layer around the stack the deven is hauled by a pair of bullocks, or more rarely, a horse. Being turned up at its forward end, the deven rides on top of the layer. The driver stands or sits on the deven to give it additional weight.... As the deven goes round and round the stack, the flints in its under surface cut the stalks of grain into short pieces and remove the kernels of grain from their 
heads. Every few minutes the layer is stirred and turned, so that no kernel shall be left in its head. When inspection shows that the process is complete, the mixture of chopped-up straw and grain is pulled down from the stack. ... When the entire stack has been ground up in this manner, the winnowing begins.

The fact that the word kišzappum or kirzappum means "threshing board" in our texts does not exclude the meaning "footstool" in other texts. In Akkadian, the word denoted originally a footboard, that is, simply the board on which one stood. The secondary meaning "footstool," namely, the board on which one rested one's feet, could easily have been developed from it. In Sumerian, the logogram GIŠ.GİR.GUB, “footstool,” is clearly distinguished from GIŠ.BAD, "threshing board."

Line 20.-For GIŠ.ŠUBUR in this line as well as in lines 23 and 55 in this inscription see Deimel, $\breve{S} L$ II 53:4. In a slightly different form this logogram appears also in our text no. 39:1.

Line 22.-- Tarkullum or tirkullum is the pole used as the mainmast on ancient ships. See A. Salonen, "Die Wasserfahrzeuge in Babylonien," Studia Orientalia VIII 4 (1939) pp. 111f. and 127.

Line 25.-For the element $K i$-dè in the personal name ME-Ki-dè cf. the Old Akkadian personal name NIN-Ki-dè in E. Burrows, Archaic Texts ("Ur Excavations Texts" II [London, 1935]) pl. XLVIII, no. 33:4, and the geographic name $K i$-dè ${ }^{\mathrm{KI}}$ discussed below under line 50.

Line 32.-With Ib-ri-me in our text may be compared the geographical name $I b-r i-m e^{\mathrm{KI}}$ in two texts of the same period from Tell Asmar (MAD I 18:2 and 57 rev. $\mathrm{x}+2$ ).

Line 34.-Comparison of GIŠ.KA! ÚR + KÍD in our text with GIŠ.SAG DUBBIN in the late syllabary published by Meissner in AOTU I 1, p. 59:50f., makes it clear that the sign ÛR + KÍD in our text is a defective writing for DUBBIN (composed of KAD+ KÍD + ÚR). According to this syllabary the logogram denotes some part of a wagon, perhaps a part of the wheel. Cf. also x GIŠ.KA [GIŠs. DUBBIN] in MAD I 325:2 and KA GIŠ.DUBBIN in ThureauDangin, ITT I p. 28, 1429.

Line 37.-GIŠ.NAG.BAL occurs often in the Old Akkadian and Ur III texts and denotes some object made from the wood of the HAŠHUR-tree. Cf., for example, GIŠ.HAS̆HUR NAG.BAL in De Genouillac, ITT II 1, 4644:1, or GIŠ.NAG.BAL GIŠ.HAS̆HUR, ibid. no. 4646:1 (references supplied by Dr. Geers). 
Line 40.--The name ${ }^{\mathrm{d}}$ UTU-SA is evidently identical with ${ }^{\mathrm{d}} \mathrm{UTU}-\mathrm{E}^{-}$in nos. 18:3 and 19:9, although the confusion between SA and the similar in form sign E cannot be epigraphically explained. Cf. ${ }^{\mathrm{d}} \mathrm{UTU}-\hat{\mathrm{E}}$ and ${ }^{\mathrm{d}} \mathrm{UTU}-\mathrm{SA}$ (MAD I p. 226 passim), DINGIR-É

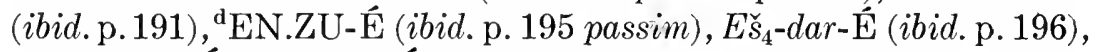
and $B a-l u h-\hat{E}, B a-l u-u ́ h-\hat{E}$ (discussed above under no. 18:17). Note the remarks in MAD II 62.

The ending -ša in the names Ba-lu-sa (1. 27), KUG.BABBAR-sa (nos. 21:3 and 49:10), Mim-ma-sa (no. 37:5), Šum-ma-sa (no. 11:14), $E$-lu-sa (no. 28:9), and $M e-\grave{u}$-sa (nos. 18:2 and 19:6) is best explained as the feminine singular pronominal suffix.

Line 41.-The order KUŠ.LAL.A.GÁ here and also in no. 34:7 is unusual as against the normal KUŠ.A.GÁ.LAL (Deimel, $\breve{S} L$ II 7:183). The corresponding Akkadian word is naruqqum, not "ein Teil des Schuhes" as translated by Deimel, loc. cit., but "sack," used for carrying and measuring grain and flour. Especially instructive is the comparison of 4 KUŠ.LAL.A.GÁ ZÍD.Š́E, " 4 sacks of barley flour," in our text no. 34:7 with such examples as 6 na-ru-uq qé-mu-um, "6 sacks of flour," in a Cappadocian tablet published by Clay, BIN IV 188:19f., and elsewhere. See also n. to no. 34:4.

Line 42.-I do not understand GIŠ $e$-ni Ù.URU.A. With the first word cf. possibly $e-n u$ in no. 7:21; with the second, the phrase $b a-l a$ U.URU +A in no. 40:6.

Line 47.-Normally we should expect in this line some such verbal form as "they brought" or the like (as in line 52). Since it is impossible to derive such meaning from GU.GU.TUR, it is necessary to assume that the verb was omitted, as so frequently in our schematically written tablets (on this problem see pp. 175f.). Then GU.GU.TUR should express the name of a person. Gugu as a personal name appears frequently in the texts of the Third Dynasty of Ur (see Schneider in Orientalia XXIII 39). On the use of GAL, "the Elder," and TUR, "the Younger," in personal names see Meek, HSS X p. xv.

Line 50.- Our geographic name $K i$-d $\dot{e}^{\mathrm{KI}}$ is evidently identical with $K i-t i^{\mathrm{KI}}$, found frequently in the tablets of the later periods from the Diyala region. See H. Frankfort, S. Lloyd, and T. Jacobsen, OIP XLIII 189. For the reading URU-Gi-tim see n. to no. 25:9.

Line 61.-The occurrences of gold are rather rare in Old Akkadian, as the chief metal of exchange commerce was silver. The relationship in value of gold to silver is $8: 1$ according to the text in 
De Genouillac, ITT II 2, 4647 and 71/2:1 according to an unpublished text Louvre AO 8638.

Line 62.-The spelling ŠÁM-mu-su shows that the word for "price" is a plurale tantum, as normally in other texts of Old Akkadian period; cf., for example, ŠÁM-me above (no. 10:9). 


\section{4 (FM 229202)}

A list of objects and provisions similar to no. 33 except that there are no accompanying personal names.

Several of the signs in this inscription are peculiarly written; evidently the scribe was not well versed in cuneiform writing. Cf. the sign MU in line 3 , ŠAKAN in line 5, TÚG in lines $6,10,11,12$, GÍD in line 8 and perhaps also in line 12 .

\section{Transliteration AND Translation}

Obv. 1) $\left.{ }^{\lceil} x\right\rceil+2$ KUŠ MÁŠ

2) nam-ha-ru ZÍD. ̌̀ E

3) 1 AN.ZA.MU

4) 2 EDIN.A.SU

5) 2 ŠAKAN IÀ.NUN. DÜG

6) TÚG.GU.ZI.DA. SÍG

7) $30(\mathrm{QA})$ ŠE 4 KUŠ. LAL.A.GÁ ZID.Š́E

8) 2 GIŠ.GÍD

9) $[1 M] A . \mathrm{NA} S I ́ G$ ÍB. $L A L$

Rev. 10) 2 TÚG. ̌́AG 4 .GA.DÜ

11) 1 TÚG.SÍG

12) 1 TÚG.(erasure)GÍD

13) 2 HI.HI.NA $\left.{ }^{\top} \mathrm{X}\right]+2$ kidskins

containers for/of barley flour,

1 pot,

2 water-skins,

2 jugs of sweet butter,

(1) woolen GU.ZI.DA-garment, 30 QA of barley, 4 sacks of barley flour, 2 wooden staffs, 1 mina wool-girdle,

2 ŠAG 4 .GA.DÜ-garments, 1 coat, 1 mat, 2 HI.HII.NA-garments. 


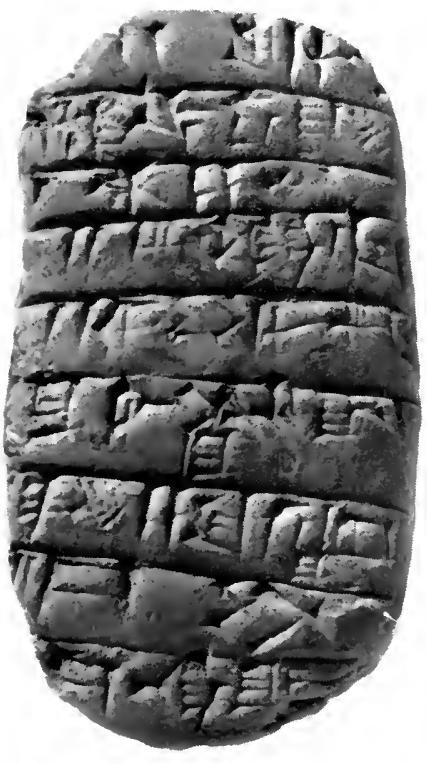

Obverse

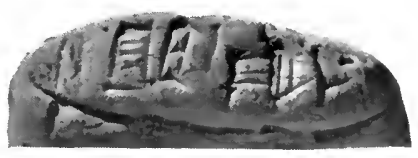

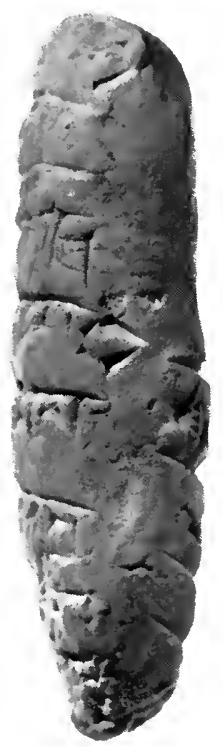

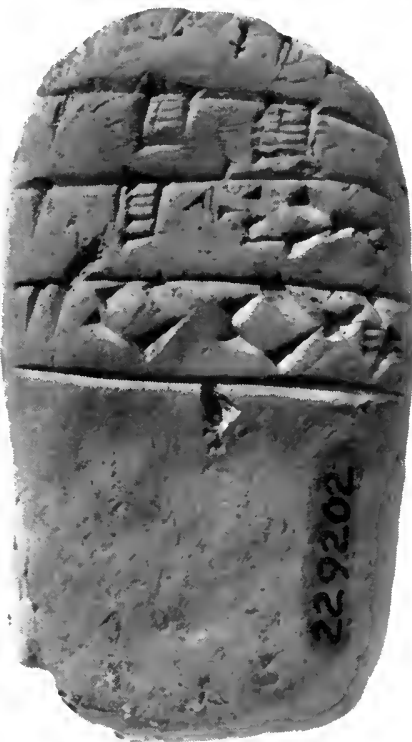

Reverse

TABLET 34 (FM 229202) 


\section{NoTES}

Line 3.-The last sign in AN.ZA.MU is not very clear, but it cannot be AM. The logogram probably corresponds to AN.ZA.AM,

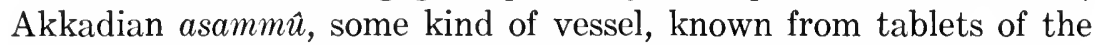
Third Dynasty of Ur, for example, in-Pinches, The Babylonian Tablets of the Berens Collection (London, 1915) no. 89 ii 14f.; Hackmann, BIN V 2:36, and in a syllabary published in II $R 44$ no. 8; see also Pinches, op. cit. p. 110, and Langdon in RA XV (1918) 158.

Line 4.-The logogram EDIN.A.SU (also in no. 7:11) is probably identical with SU.A.EDIN.LAL, Akkadian nâdu, "water-skin" (Deimel, $\check{S} L$ II 7:184 and 579:219). Cf. also KUŠ.EDIN.A.SU in Thureau-Dangin, RTC 222 rev. i 7 and 8; 225:3; etc. Similar cases of logograms with and without LAL can be observed in the comparison of KUŠ.LAL.A.GÁ, discussed above under no. 33:41, with KUŠ.A.GÁ in our no. 48:3 and 6 and in an Old Akkadian tablet transliterated in Thureau-Dangin, ITT I 1210. Cf. also 9 KUŠ!. A.GÁ and 1 KUŠ.A.GÁ.LAL in Dossin, Mém. XVIII 83:5f., which suggests that the two logograms denote two similar but slightly differentiated objects.

Line 5.- $\breve{S} A K A N$ is a jug or pitcher used for carrying butter and other fats; it is used also as a measure. See Deimel, $\check{S} L$ II 428:1-5.

Line 6 .- The reading of the sign SÍG, although not clear on the tablet, is made plausible by the fact that the kusitum-garment is sometimes made of wool. On this problem see n. to no. 7:3.

Line 9.--The reading of [ $1 M] A$.NA $S I ́ G / T U G G$ ÍB. $L A L$ is doubtful but it receives a certain amount of support from the occurrence of 1 SÍG ÍB.LAL in an unpublished text in the Yale Museum. ÍB.LAL occurs also below in no. 38:5. For TÚG.ÍB.LAL see Deimel, $\breve{S} L$ II 207:35; for the translation "girdle" cf. Gadd in Studia Orientalia I (1925) 28 and 30.

Line 10.-On the $\check{\mathrm{S} A G_{4}}$.GA.DÜ-garment see Deimel, $\breve{S} L$ II $536: 244$, where, however, only the reference to De Genouillac, Tablettes de Dréhem (Musée du Louvre, "Textes cunéiformes," vol. II [Paris, 1911]) 5496, is correct. For the older periods see, for example, Thureau-Dangin, RTC 102 ii $\mathrm{x}+4$, and in our collection no. $7: 6$.

Line 11.-The word TÚG.SÍG is equated in Deimel, $\breve{S} L$ II 536:291 with Akkadian ulinnu and sissiktu, some kind of coat. 
Line 12.-Our TƯG.GÍD (written over erasure) is perhaps identical with TƯG.GÍD, having the Sumerian reading mudru and the Akkadian equivalent burû, "mat." See Deimel, $\breve{S} L$ II 536:229 and Meissner in MVAG XII 3 (1907) p. 162. The signs cannot be read as TÚG.UŠUM.

Line 13.-The same ending as is found in HI.HI.NA occurs in

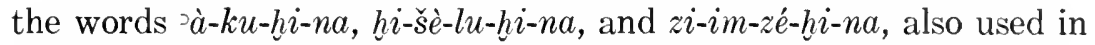
connection with garments, in an Old Akkadian text published in Hilprecht, $B E$ I 11. The suffix -hina looks foreign and may serve as a gentilic-adjectival formation with words denoting the origin or quality of garments. See also Gelb, Purves, and MacRae, OIP LVII under -hina. 


\section{5 (FM 229241)}

A very interesting text in view of the fact that the mode of expression changes from indirect to direct discourse. The contents of the inscription are as follows: According to lines 1-6 Siwira, Tešîtum, and Tâb-ilì each took certain amounts of silver. Then in lines 7-10 it is said that he - evidently Tâa-ili-gave to me-an unknown person - certain garments and a specified amount of silver. In the last line the unknown person gave to "him"- - that is, to Ṭâb-ilì-a certain garment.

\section{Transliteration and Translation}

Obv. 1) 5 GÍN KUG.BABBAR 5 shekels of silver

2) $\check{u} u S i-[w] i-r a \quad$ of Šiwira,

3) 1 GÍN KUG.BABBAR 1 shekel of silver

4) $\mathrm{Te}$-si-tum (of) Tešîtum

5) 1 GÍN KUG.BABBAR 1 shekel of silver

Rev. 6) Tab-i-li

7) $1^{\text {TÚG }} b u$-ru-tum (of) Tâb-ilī,

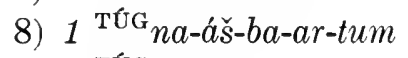
1 burutum-garment,

9) $1^{\mathrm{TUG}} z i$-im-tum 1 našpartum-garment,

10) 1 GÍN KUG $i$-ti-nam 1 simdum-garment,

11) 1 TÚG.BAL ${ }^{\top} a^{\top}-t i$-šum 1 shekel of silver he gave to me. 1 BAL-garment I gave to him. 


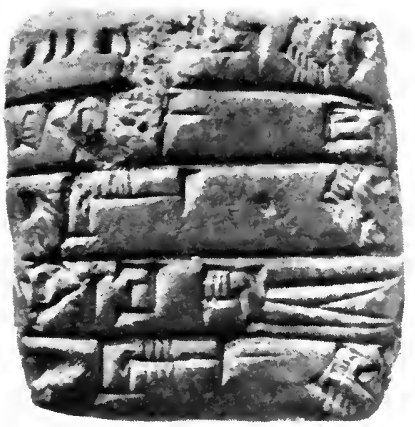

Obverse
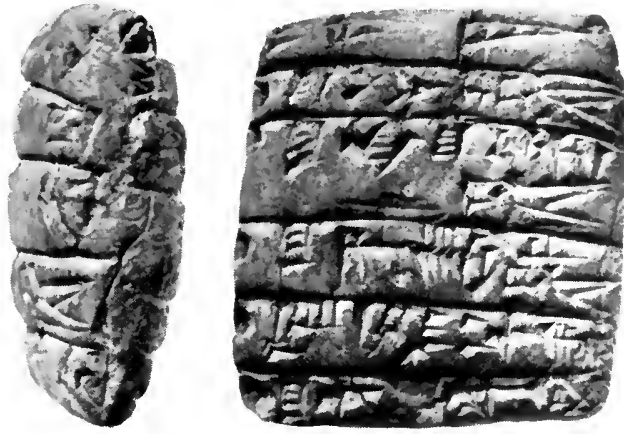

Reverse

TABLET 35 (FM 229241)

\section{Notes}

Line 2.-The reconstruction of the name $S i$ - $[w] i-r a$ is based on its clear occurrence in $M A D$ I 163 iii 29.

Line 6.-The name TAB-NI-NI is taken here as Tab-i-lí = Tâbilī, but possibly it could also be interpreted as Tabnî-ilī or Tappä-ilī.

line 8.-The na-áš-ba-ar-tum-garment is probably identical with the na-áš-ba-ru-um-garment frequently found in the tablets of the Old Akkadian period, as in Thureau-Dangin, ITT I p. 5, 1082; De Genouillac, ITT V 9297:1; MAD I 169:3.

Line 9.-For the translation of simdum see the discussion under no. $7: 8$.

Line 10.-For the writing of KUG.BABBAR as KUG see Deimel, $\check{S} L$ II 468:4. The writings KUG and KUG.BABBAR are both represented in Thureau-Dangin, RTC 101 and in MAD I 302.

Line 11.-The BAL-garment occurs in the form TÚG.BAL in De Genouillac, ITT V $6674 \mathrm{x}+2$, and elsewhere, in the form TUG. TÚG.BAL in MAD I 187:22. 


\section{6 (FM 229248)}

Tablet concerning barley, field, and wool (lines 1-24). Following a small blank space on the tablet, all those items are summarized in lines 25-30. Unfortunately the closing lines are not sufficiently well preserved to allow of an interpretation with any degree of certainty. Tablet no. 36 resembles in appearance no. 7 , both being presumably written by the same scribe.

\section{Transliteration AND Translation}

Obv. 1) 10 ŠE.GUR ŠE.HAR. 10 GUR of HAR.AN-barley $\mathrm{A}[\mathrm{N}]$

2) Na-bi-um ik-sur

Nabi ${ }^{\top}$ um ....-ed.

3) 10 (GUR) Na-bi-um

10 GUR Nabi’um

4) $a-n a E-n a-n a$ to Enana

5) EDIN $i$-dim the potter gave.

6) ŠE.HAR.AN È-ni-um

7) $\check{s} u N a-b \imath-u m$ Of the HAR.AN-barley of Enium

8) in i-te-su

9) $i k-s u_{4}-r a$

10) 10 (GUR) $i[n]$ É- $t i$

11) $L a$-n[i] SAL.LÚ.TÚG

12) 5 (GUR) $[i] n$ É-t $i$

13) TÚG.DU ${ }_{8}$

14) 5 (GUR) [...]-lum

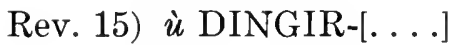

16) in [...]-tim

17) $I$-[n]a-na-num which Nabi’um in/with his .... .....ed, 10 GUR are in the house of Lan[i] the woman-fuller, 5 GUR are in the house of the upholsterer, 5 GUR of ... .lum

18) 30 'SÍG ${ }^{\top}$ MA.NA and of Ilum-. . . . in [. .]. .

Inananum (received).

19) in $\mathrm{NA}_{4}$ KUG.BABBAR (measured by) the "stone of silver,"

20) Bi-za-num Bizanum

21) $w a-b i ́ l-s i-i n$ is their porter.

22) 5 (GUR) Bi-za-num 5 GUR (of barley), Bizanum

23) $[w] a-b i l-s u$

24) 14 ' GĀN (space)

25) $[\check{S} U \cdot N I G I ́ N] 45$ ŠE.GUR is its porter.

[4] GÂN of field. (space)

[Total] 45 GUR of barley, 
26) $[\check{S} U-N I G I ́ N] 4 \mathrm{GÁN}$ 30 SÍG MA.NA

27) $[\ldots$. . d]a $N a-[b] i-u m$

28) $[$....]-tum a-pù-su

29) [šu-ut a]-na É-ti-su $-n u$

30) $[u]-s[a ́-r] i ́-b a$

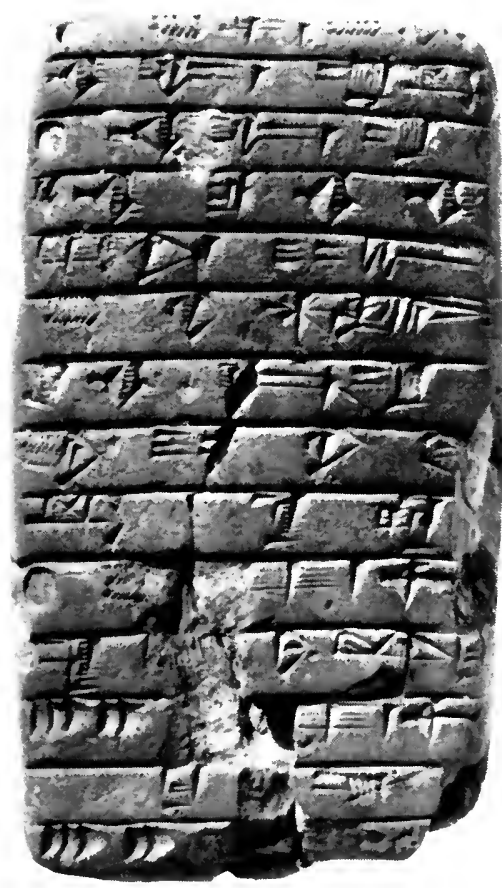

Obverse
[Total 4 GÁN of field, 30 minas of wool, [..... Nabi'um $[\ldots]$ tum his father, [which in] to their house [caused to enter].

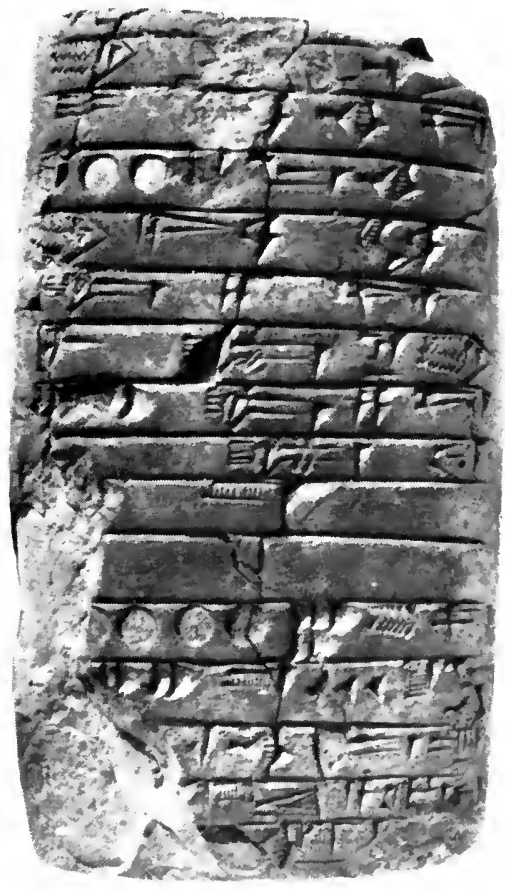

Reverse

TABLET 36 (FM 229248)

\section{Notes}

Line 1. - ŚE.HAR.AN (here and in line 6) denotes probably barley of a certain quality. To my knowledge, this word is attested nowhere else.

Line 2.-Ik-sur in this line, $i k-s u_{4}-r a$ in line 9 , and $i k$-su-ra in

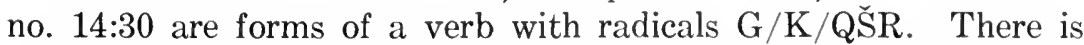
in Akkadian a verb GŠR, pret. igšir, pres. igaššir, meaning "to make strong," "to fasten," as well as a verb KŠR, pret. ikšur, pres. ikaššar, meaning "to repair" or the like. But these meanings 
seem hardly appropriate in connection with barley. W. Gesenius, Hebräisches und aramäisches Handwörterbuch über das Alte Testament ed. F. Buhl (14th ed., Leipzig, 1905) p. 669a, tentatively connects the Hebrew word QŠR, "to bind," with Akkadian KŠR, "to repair," on the basis of the assumption that the original meaning of the latter may have been "to join." This meaning fits the context of our tablet better.

This verb occurs in the form a-ga-sa-ar (also with barley as object) in another Old Akkadian text in Meek, HSS X 5:15, translated by Meek, op. cit. p. xix, as "I will make it good." Comparable perhaps is also É $k i$-šè-ir-tim, ibid. no. 10:8. From our text it seems that the verb KŠR expresses some agricultural activity in connection with grain. See also n. on line 8.

Line 5.-On EDIN, “Tonnen-Töpfer,” see Deimel, $\breve{S} L$ II 168:10.

Our verb $i$-dim might possibly be connected with the verb adāmum, meaning "to procure," found frequently in the Cappadocian texts (see J. Lewy in $Z A$ XXXVIII 249). But since this verb is found nowhere else in Akkadian literature, and since even in Cappadocian its use is restricted to the permansive, it seems doubtful whether the two passages allow of comparison.

More plausible seems the explanation that $i$-dim stands for $i$-din. This is not so far-fetched as it may appear at first glance, because several other instances in which a word with final $n$ is written with a syllable ending in $m$ are known. See the writings $i \check{s}-k u m$ and $l i$-šà-ki-im from ŠKN or $i$-na-di-im and $i$-na-ti-im from NDN cited by Gelb in AJSL LIII 184. Similarly, the geographic name Taškun-Eštar is written three times as $T a-a \check{-}-k u-u n-E \check{s}_{4}-d a r$, but once as $T a-a s ̌-k u-u m-E \check{s}_{4}-d a r$ in the Old Babylonian tablets referred to by L. Waterman, Business Documents of the Hammurapi Period (London, 1916) p. 30. The best parallel to our case is found in ŠU.NIGÎN 10 GIŠ.IŠ.DÉ É $D a-b a-l u m a$-na Ku-ku $i$-dí[m], "total of 10 IŠ.DE-logs of a house D. gave to K.," in an unpublished Old Akkadian text Iraq Museum no. 28860.

Line 6.-Although $\grave{E}-n i$-um looks like an adjective construed with ŠE.HAR.AN it should be interpreted as a personal name in view of the occurrence of this name in no. 7:30.

Line 8.-The interpretation of in i-te-su as in itēšu, "within his boundaries," that is, "within his territory," or as in iděšu, "in/by his hands/sides," does not seem plausible. Perhaps we have here the agricultural implement $i t t \hat{u}$, on which see Meissner in AOTU I 1, p. 34. According to the text discussed by Meissner, ittû has a 
peg (sikkatu), a bowl (itgurtu), and a hole (pilšu). Still another interpretation would result from translating in ittišu as "in his term."

Line 11.-- The sign $\mathrm{n}[\mathrm{i}]$ in this personal name is not clear, but its reconstruction is rendered plausible on the basis of comparison with La-ni in Scheil, Mém. II p. 47, and Meek, HSS X 205:3. On the rendering of LÚ.TUGG as "fuller" see n. to no. 16:7.

Line 13.-The profession TÚG.DU $\mathrm{U}_{8}$ occurs frequently in Old Akkadian and texts of the Third Dynasty of Ur; see Meek, HSS X 222 ii 9; Thureau-Dangin, ITT I p. 20, 1314; De Genouillac, ITT II 3488 rev. 4; 4192:11; etc. Thureau-Dangin, loc. cit., translates the word as "tisserand," in English "weaver." Deimel's translation in $\breve{S} L$ II 167:40 as "upholsterer" seems to fit some Old Akkadian texts soon to be published. 


\section{7 (FM 229250)}

The tablet deals with the distribution of animals, skins, garments, etc. to various individuals. The end of the text presents a certain amount of difficulty; if my understanding of the text is correct, the silver was taken by Ginunu, while Bêlī-țâb received bread, oil, and straw.

\section{Transliteration AND Translation}

\begin{tabular}{|c|c|c|}
\hline Obv. 1) & 2 MÁS̆ & 2 kids \\
\hline 2) & $I-s u-G I$ & Išû-kîn, \\
\hline 3) & KUŠ GUD & (1) oxskin \\
\hline 4) & $U m-m i-E \check{s}_{4}-d a r$ & Ummī-Eštar, \\
\hline 5) & $1 \mathrm{SILA}_{4}$ Mim-ma-sa & 1 lamb Mimmaša, \\
\hline 6) & $1 \mathrm{DUN}$ & 1 pig \\
\hline 7) & ARÁD-zu-ni & Warassuni, \\
\hline 8) & $m a-a d-l a ́-u m$ & (1) pail \\
\hline E. 9) & TÚG.TÚG & (and 1) TÚG-garment \\
\hline v. 10) & $M a-s ̌ u m$ & Mašum, \\
\hline 11) & 2 TÚG !.SÍG & 2 coats \\
\hline 12) & $\grave{I}-l i ́-l i ́$ & Ilili, \\
\hline 13) & KUG.BABBAR & silver \\
\hline 14) & Gi-nu-nu & Ginunu, \\
\hline 15) & $B e-l i$-DÜG & Bêlī-țâb \\
\hline 16) & NINDA IÀ & bread, oil, \\
\hline 17) & IN.U & (and) straw. \\
\hline
\end{tabular}



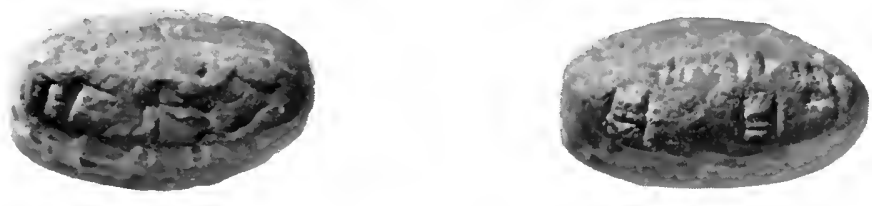

Lower Edge

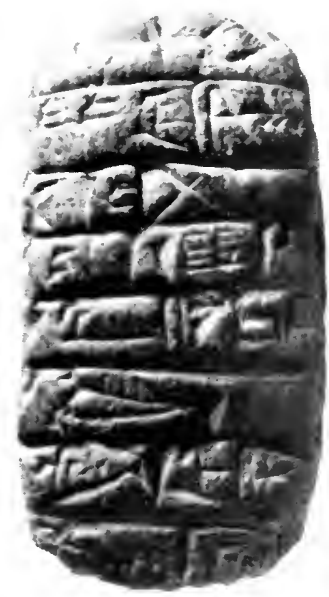

Obverse

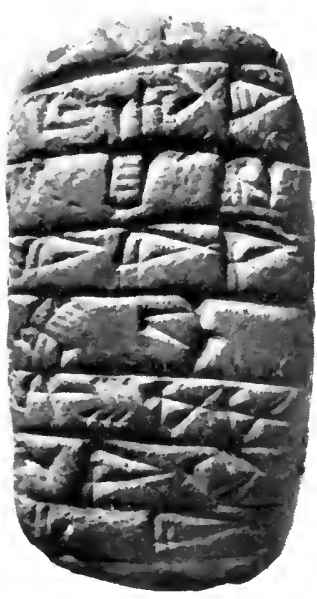

Reverse

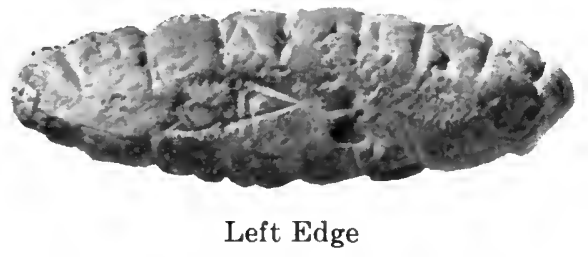

TABLET 37 (FM 229250) 


\section{Notes}

Line 5.-The personal name Mim-ma-sa occurs also in other Old Akkadian tablets, such as Scheil and Legrain, Mém. XIV $31 \mathrm{x}+4$ and $M A D$ I 163 iii. See also the discussion on mim-ma-su under no. 8:14.

Line 8.-The word ma-ad-lá-um of our text may possibly be identical with madlu, a contracted form found in later texts. For references see Scheil in $Z A X$ (1895) 202:10; Thureau-Dangin, ibid. XVII (1903) 199f.; and Muss-Arnolt, Assyrisch-englisch-deutsches Handwörterbuch p. 1016a, who all read šadlû. Bezold, Babylonischassyrisches Glossar, p. 106a, reads this word as madlu, from the root $D L_{6}{ }_{6}$, "to draw water," and proposes for the noun, though with due hesitancy, a translation "a receptacle for drawing water."

Line 9.-TÚG.TÚG occurs also in an Old Akkadian tablet, $M A D$ I 171 and possibly in our no. 38:2.

Line 12. - The reading of NI.NI.NI as $\bar{I}-l i-l i$ is based on the occurrence of the form $I$-li-li beside $I$-li-li in the texts from Gasur. See Meek, HSS X p. xxxiii. On the reduplicated form see the remarks on p. 325 .

Lines 16f.-No other explanation suggests itself for the signs GAR NI IN.U in these lines than to read them as NINDA IA IN.U and translate "bread, oil, (and) straw." The writing IN.U for the normal IN.NU is known in texts of the Third Dynasty of Ur. Cf., for example, IN.U ŠAG ${ }_{4}$.GAL GUD.ŠE, "straw for fodder of fattened oxen," in Hackmann, BIN V 228:7, and similarly ibid. no. 229:4; C. E. Keiser, Selected Temple Documents of the Ur Dynasty ("Yale Oriental Series," vol. IV [New Haven, 1919]) 256 iv 76; Barton, Haverford Library Collection of Cuneiform Tablets or Documents from the Temple Archives of Telloh III (Philadelphia, no date) pl. 122, no. 259:6; Legrain, Le temps des rois d'Ur, Planches (Paris, 1912) 376:9 (references supplied by Dr. Geers). From the occurrence of GIŠ́.GIGÍR IN.U, "wagon(load) of straw," in an Old Akkadian tablet in Meek, HSS X 203:4 we know that straw was measured by wagon loads, just as in modern farming practice.

NINDA IÀ occurs also in other tablets of this collection, for example, in nos. 42:10 and 48:4. They represent the staple food of the ancient Mesopotamians. 
38 (FM 229214)

A small tablet with badly preserved signs. A list of entries with no details of ownership.

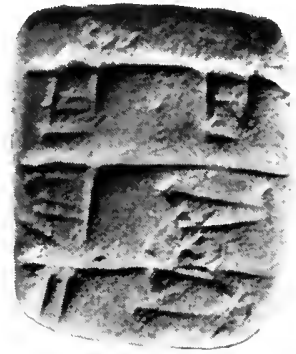

Obverse

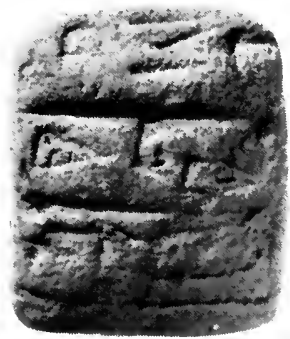

Reverse

TABLET 38 (FM 229214)

Transliteration and Translation

Obv. 1) $\check{S} E$

2) TÚG.TÚG

3) KUŠ.DUN

4) 2 AMAR

Rev. 5) İB.LAL

6) IÀ.SIG.A

7) GIŠ.APIN
Barley, TÚG-garment, pigskin

2 calves, girdle, thin oil, plow.

\section{NoTES}

Line 2.-The signs look like TÚG.KU, but perhaps they are miswritten for TÚG.TÚG, which occurs in text no. 37:9, q.v.

Line 3.- On the form of the sign DUN see the remarks in the Introduction, p. 177. Cf. also KUŠ DUN in ITT V 9308 rev. 3. The DUN-animal denotes a pig in the old texts, according to Deimel, $\zeta L$ II 53:1 and 467:1. Skeletal remains of pigs have been found in great numbers in the Diyala region (see Hilzheimer, Animal Remains from Tell Asmar pp. 27-32). In fact, according to Hilzheimer, the largest percentage of skeletal remains found at Tell Asmar were those of pigs (ibid. pp. 47f.).

Line 5.-For İB.LAL, see n. to no. 34:9.

Line 6.-The Sumerian word SIG has the meanings "weak," "small," "thin," and it is used in connection with grain, bread, and garments; see Deimel, $\check{S} L$ II 592. The meaning "late" (for which see Landsberger in $A O F$ III [1926] 164-172), used with reference to oil, that is, oil made from late olives, could also be considered. 


\section{9 (FM 229216)}

Distribution of pieces of wood, trees, and perhaps alloyed copper to various persons.

\section{TrANSLiteration AND TRANSLATION}

(3 lines erased)

Obv. 1) GIŠS.S̆UBUR

2) GIŠ $u-r i-i[m]$

3) $\mathrm{Li}$-bur (space)

Rev. 4) LÙ.LÙ.URUDU (space)

5) GIŠ. ....

6) Ad-mar

7) DINGIR-GI

8) Be-lí

9) DUMU $B u-b u$

10) $I-z u-u r-b a-s[u]$

L.E. 11) DUMU AMA.TU 'UGULA' NAGAR
(3 lines erased)

SUUBUR-trees

wood for the roof

Libûr.

(space)

Alloyed copper, (space)

.....-tree

Admar, Ilum-kîn,

Bêlì

son of Bubu, Ișșur-pašu

son of AMA.TU 'foreman' of the carpenters.

\section{Notes}

Lines $1 f$.-From comparison with $2^{\text {GIŠ }} a$-za-an GIŠ 5 GIŠ.K[A], "2 myrtle trees, wood for 5 pegs," in no. 33:5f. we can deduce that GIŠ.ŠUBUR GIŠ $u-r i-i[m]$ in our text should be translated as "ŠUBUR-trees, wood for the roof." However, cf. also GIŠ $u$-ri-e, "beams" (acc. plur.), in Lutz, Early Babylonian Letters ("Yale Oriental Series," vol. II [New Haven, 1917]) 117:17 and 20. Possibly the same word is used for "beams" and "roof" in Akkadian, owing to the fact that in the oriental adobe houses, roofs were made of beams. For GIŠ.ŠUBUR see n. on no. 33:20.

Line 3.- Li-bur here and in no. $48: 1$ is interpreted as a personal name because of its similarity to $L i$-bur-ri-im in no. 30:5 and $L i$ pù-ru-um in no. 49:6. For the formation Libûr, "may he be firm!," cf. Liblut, "may he live!," in Old Akkadian texts, MAD I 233:4 and 265:17.

Line 4.-The Sumerian logogram LÙ.LÙ corresponds to Akkadian bullulum, and it is used with reference to mixing and smelting of metals. See Deimel, $\check{S} L$ II 345:13. 
Line 6.-The personal name $A d$-mar occurs on numerous tablets from the Diyala region (for example, $M A D$ I $328: 5$, rev. $\mathrm{x}+3$, and 336:15).

Line 11.-The personal name AMA.TU occurs also on several Old Akkadian tablets, as in MAD I 163 iv 14, v 6, etc.

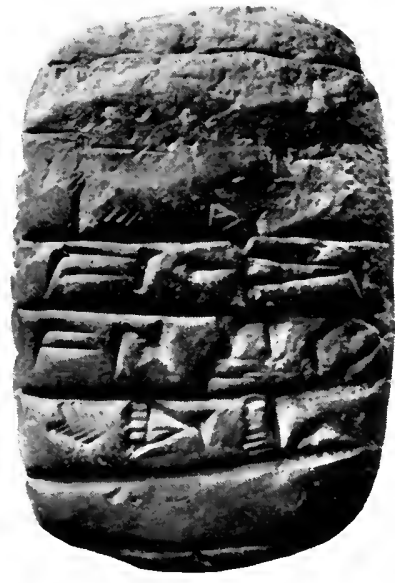

Obverse

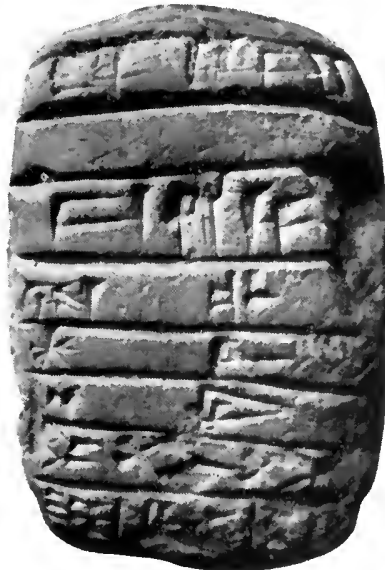

Reverse

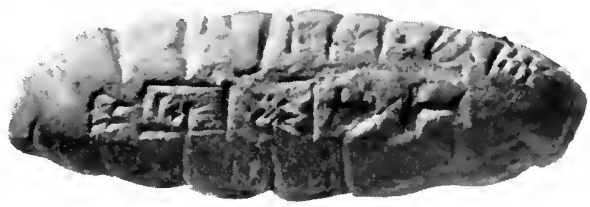

Left Edge

TABLET 39 (FM 229216) 


\section{0 (FM 229251)}

The obverse is well preserved; on the reverse some of the words are only partly readable. Since I am not sure of even one word on the whole tablet, I am forced to assume that it is a school exercise composed entirely of unconnected words. It must be admitted, however, that the tablet is not like a school tablet in form, and the handwriting is better than one would expect to find in an exercise.

\section{TransLiteration}

Obv. 1) $\grave{u}$-wa-am $\grave{u}$-im

2) $z a-l a-a m$ ZÍD.IM

3) $1 \mathrm{NUM}$

4) $\grave{u} m u-u \check{s}-t \grave{\text {-num }}$

5) $1 \mathrm{DU}$

6) $b a-l a$ Ù.URU +A

7) $\check{s} a-m a-a k-t u m$

8) $t u-n u-\operatorname{ar}[-\mathrm{x}]$

Rev. 9) la-gi-tum

10) $s i-i p-t e-[\ldots]$

11) ma-tim [...].

12) me-en-[...].

13) $a-n[a \ldots .]-.m e$

14) $[\ldots] T U \dot{G} \cdot S I G_{5}$

15) s[a-t]u-e a-ri-im

16) [.... $]^{\mathrm{d}}$ NIN.GAL i-ti-num

17) ....-num ....

L.E. 18) $a-r i-i m$ 

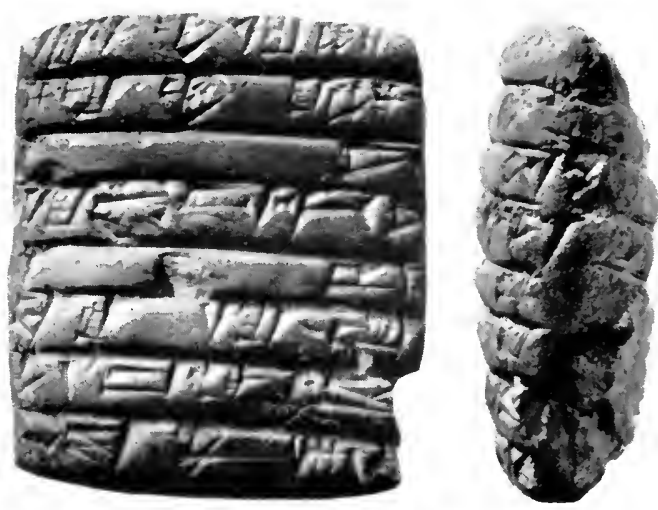

Obverse
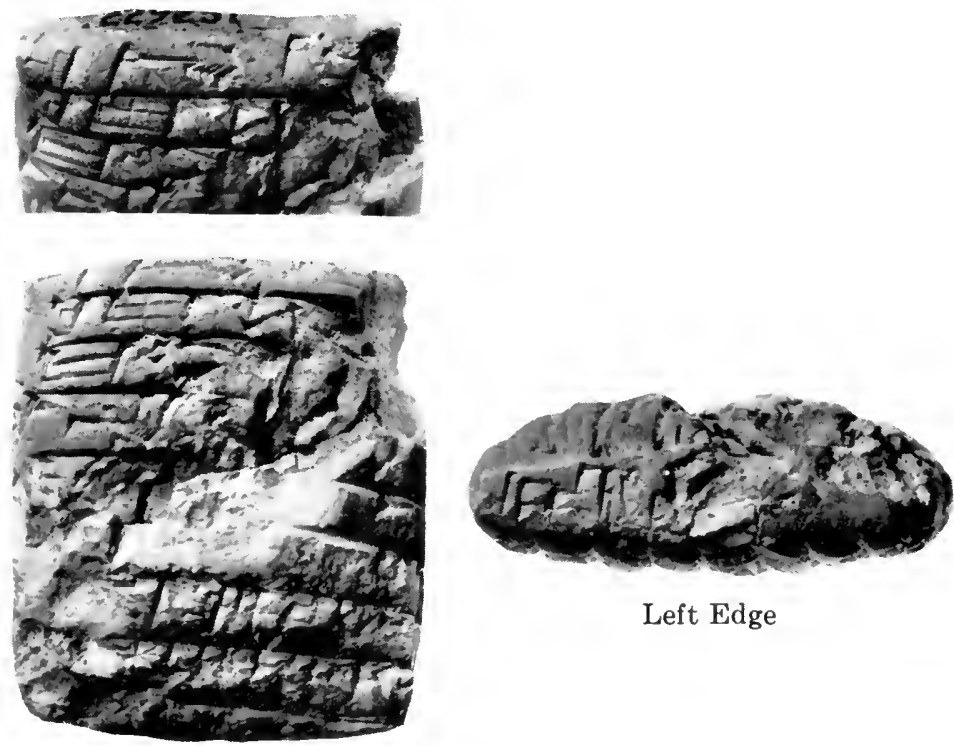

Left Edge

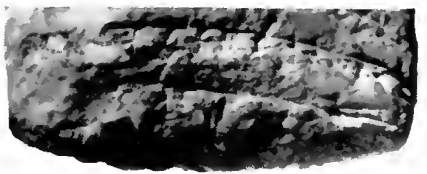

Reverse

TABLET 40 (FM 229251) 


\section{1 (FM 229221)}

List of objects or perhaps a school tablet. Obverse is readable, reverse badly preserved.

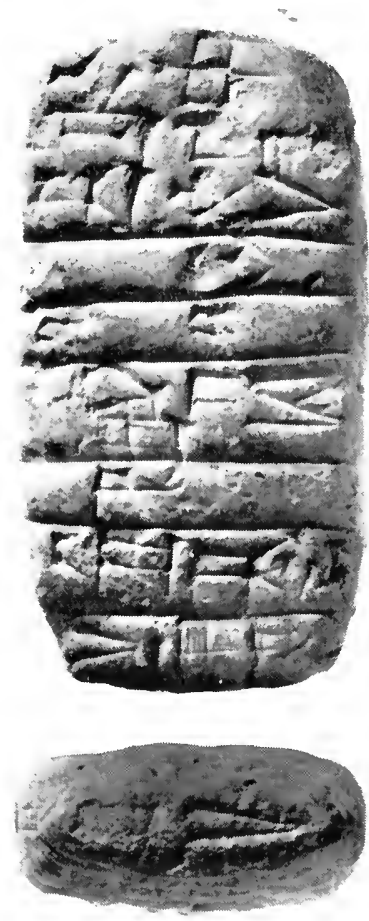

Obverse

TABLET 41 (FM 229221)

\section{Transliteration}

Obv. 1) na-ak-da-ma-at ap-tim Rev.

2) KAM

3) $\mathrm{DU}_{8} \cdot \mathrm{DU}_{8}$

4) li-tum GUR

5) GI

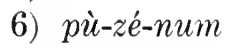

7) húp-sa-šum

8) NISABA
Rev. (double line)

9) šu $a-n a x-x$

10) GIŠ $x-x$

11) TÚG.TÚG $x-a-n i$ SI.A

12) TƯG.TÚG É.GAL AL

13) 4 AMAR

14) $t i-k u m$

15) $s u / z u-m u-u k-t u m$

16) ÉŠ.KÀR

L.E. 17) GIŠ.MA 

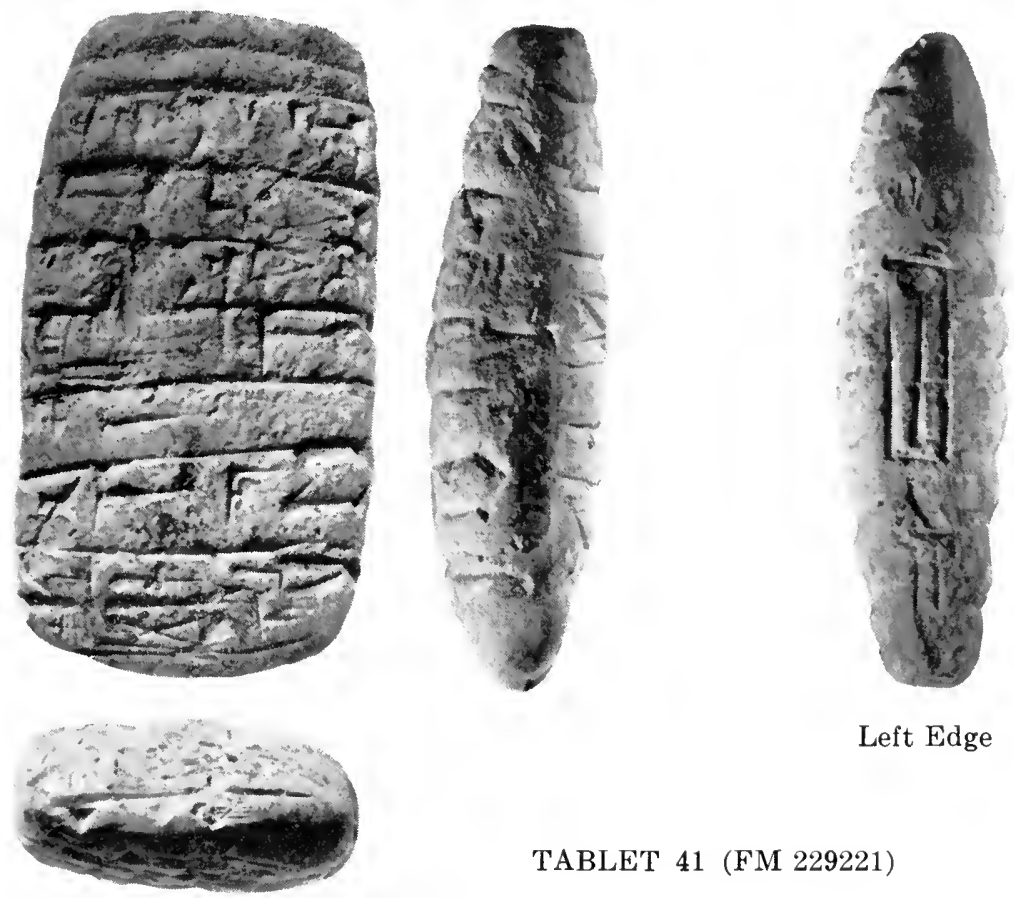

Left Edge

Reverse

TABLET 41 (FM 229221)

\section{NoTES}

Line 1.--The expression naktamāt aptim, literally "covers for the window," probably refers to the wooden shutters or blinds used to protect the window opening. The feminine form naktamtum is new; normally the masculine form naktamum is used in Akkadian. As suggested by Dr. Jacobsen, these window covers may correspond to the wooden grilles such as are used in the windows of modern oriental houses or as are found in the ancient Old Akkadian houses excavated at Tell Asmar. See H. Frankfort, Iraq Excavations of the Oriental Institute 1932/33 ("Oriental Institute Communications," no. 17 [Chicago, 1934]) pp. 13f. See also the picture of the clay window grille from Susa reproduced by G. Contenau in $R A$ XXXII (1935) 151.

Line 5.-GI, "reeds," occurs perhaps also in no. 23:7.

Line 6.-The Akkadian word businnum denotes originally the plant called in English mullein, candlewick, or high taper, in German Königskerze or Wollkraut, in Latin Verbascum thapsus, whose 
thick woolly leaves were used for making wicks for candles or oil lamps. Hence in Akkadian the same word is used also for "wick." See discussion by H. Holma in OLZ XVI (1913) $291 \mathrm{ff}$.

Line 7.-Our húp-sa-šum corresponds to hupšašûm, known from syllabaries to denote some kind of pot." See Deimel, $\check{S} L$ II 309:61 and 322:21 and 39. The syllabic value hup in the Old Akkadian period is proved by the occurrence of $a-n a$ Húp-nim ${ }^{\mathrm{KI}}$ in Meek, $H S S \times$ 92:5 (read as $K a b-n i m^{\mathrm{KI}}$, ibid. p. xlii, and as $H u \dot{u} b-n i m^{\mathrm{KI}}$, ibid. p. xlvii) as compared with $H u-u p-n i^{\mathrm{KI}}$ in Ur III texts, C.-F. Jean, Sumer et Akkad (Paris, 1923) VII 3 and the unpublished tablet Oriental Institute A 4316:7. The identity of Old Akkadian Hupnum with Hupni of the Third Dynasty of Ur is further strengthened by geographic considerations. The Oriental Institute tablet just cited contains also an occurrence of the well-known $\mathrm{GÁN}-h a r^{\mathrm{KI}}$, to be read as Kár-har ${ }^{\mathrm{KI}}$, because of a variant $H a-r a-h a r^{\mathrm{KI}}$ in the unpublished Ur III tablet A 2695 (see Gelb apud Frankfort, Lloyd, and Jacobsen, OIP XLIII 161 n.* and $A S$ no. 22, p. 57). Now, since Karhar or Harahar is identical with Harhar of the Assyrian historical inscriptions and is situated somewhere east of the Kirkuk region (see the references in R. P. Boudou in Orientalia XXXVIff. [1929] 73f.), Hupnum of the Gasur tablet should naturally be situated somewhere in the close vicinity of Gasur-Nuzi.

Line 14.-Ti-kum is perhaps equivalent to $t i g(g) \hat{u} m$, some kind of drum. 


\section{2 (FM 229207)}

The inscription is badly preserved and fails to make sense. School tablet? In line 10 NINDA IÀ is written upside down in relation to the rest of the inscription. Similarly in no. 26 .

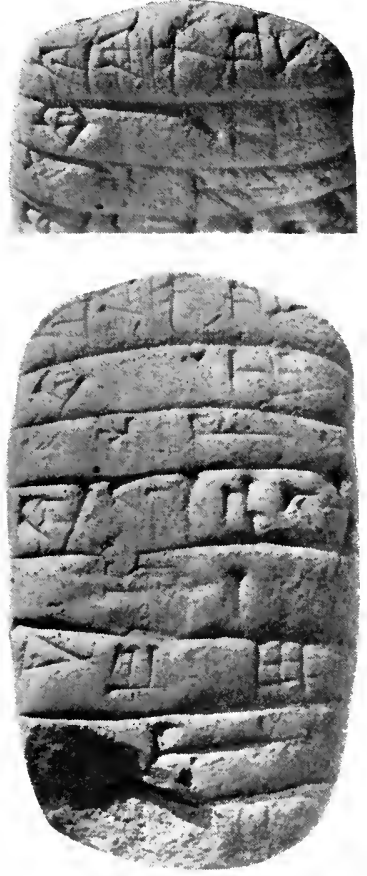

Obverse

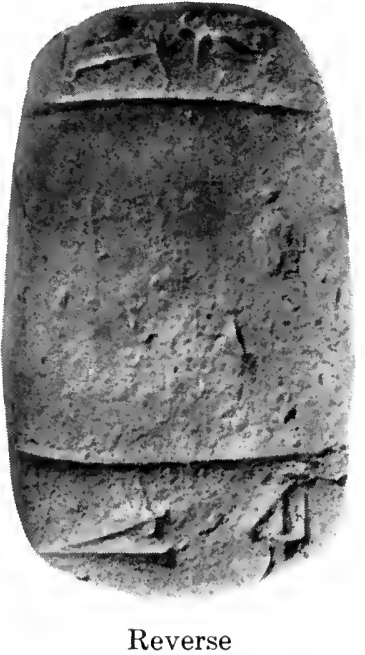

TABLET 42 (FM 229207)

TRANSLITERATION
Obv. 1) $z u-z u-u b-? \mathrm{BI}$
2) $s a ́-\grave{u}$
3) ŠE. ${ }^{d}$ INNIN
4) $Z u-z u a-n a$
5) $G \bar{A} N$
6) $\dot{I}-l u-l u$
7) $[\ldots] \mathrm{GI}$
8) $[\ldots] \ldots$

Rev. 9) $m a-\ldots$.

10) NINDA IÀ (written upside down)

\section{Notes}

Line 1.-The signs look like $z u-z u-u b$ not $s u$-su-ub.

Line 3.-With our ŠE. ${ }^{\mathrm{d}} \mathrm{INNIN}$ cf. [ک̌SE].INNIN, a kind of barley, in $M A D$ I $297: 10$. 


\section{3 (FM 229209)}

The disparate length of the lines and the general lack of any apparent connection in sense between the individual lines give the tablet the appearance of a school tablet. "Below are given some notes to words which are at least partly intelligible. Most of the words appear in plural.

\section{TRANSLITERATION}

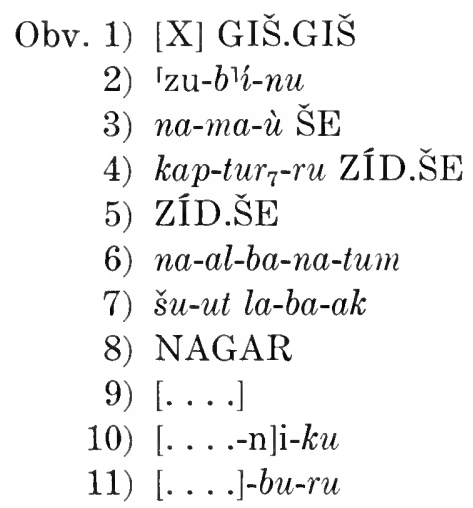

Rev. 12) ki-um

13) dah-hu NI.DU

14) $a$-ni-ik GUR

15) $u b-b u$

16) DA.NAGAR $\check{s} u$-[x]-ga-e

17) GIŠ.ŠE.Ù TUR

18) IÀ ù á-si-su

19) $a-n a \mathrm{AS̆GAB}$

20) za-bi-lu... 


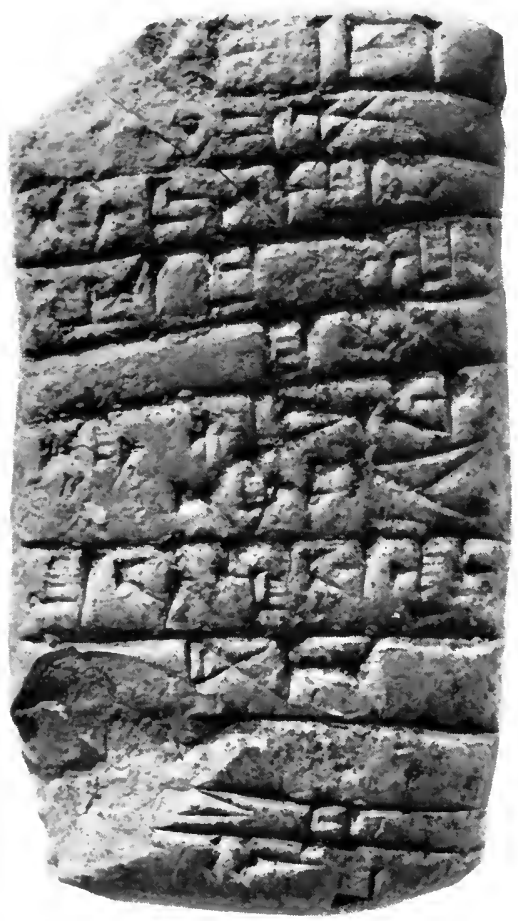

Obverse

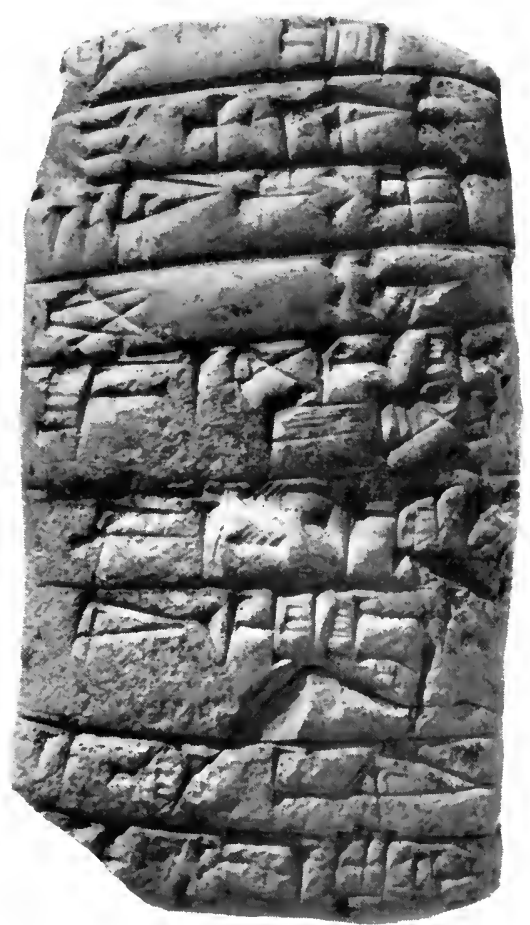

Reverse

TABLET 43 (FM 229209) 


\section{NoTES}

Line 1.-For GIŠ.GI ̌̀= epinnum, "plow," or nîrum, "yoke," see Deimel, $\breve{S} L$ II 296:79.

Line 2.-The word ${ }^{r} z u / s u^{\top}$-bi-nu may stand for later suppinnum, a metal or wooden implement.

Lines 3 and 4.- The words $n a-m a-\grave{u}$ and $k a p-t u r_{7}-r u$ are used with reference to carrying barley (ك̌SE) and barley flour (ZÍD. $\breve{S E}$ ) respectively and should denote some kind of receptacles. The first word is unknown to me. The second is probably identical with kapturrum (written kap-KU-ru), which occurs in syllabaries and is translated "ein best. Behältniss aus Leder" by Delitzsch, $A H W B$ p. $348 \mathrm{~b}$.

Line 6.-Nalbanātum, plur. of nalbattum or nalbanum, "brick mould."

Line 12.-The word $k i$-um occurs also on an Old Akkadian tablet, $M A D$ I 274:3, in a list including chariots, trees, pots, etc.

Line 15.-Uppum means "drum" or part of a door, perhaps "door-handle." The latter meaning may be preferred here if the interpretation of the word in the next line as part of a door is correct.

Line 16.-The logogram DA.NAGAR cannot denote a part of an arrow, as proposed by Deimel, $\check{S} L$ II $336: 130$, since according to the text cited by Deimel (Scheil and Legrain, Mém. XIV 86 passim) DA.NAGAR costs five shekels of silver or five times as much as a bow, which costs only one shekel of silver. In rev. col. iii of the same text we note $10+3$ DA.NAGAR LAL 3 GIŠ.TI, that is, "10+3 DA.NAGAR minus 3 arrows," implying that DA.NAGAR contained a standard number of arrows. The word may very well denote a box in which arrows are kept, while GAR DA.NAGAR (ibid. no. 7 rev. 7 and 10) would mean "a bread-box."

In our occurrence of DA.NAGAR šu-ga-e there is a break between $\check{s} u$ and $g a$, but presumably nothing is missing. The word $\check{s} u$-ga-e may correspond to Akkadian šukûm, šugûm, derived from Sumerian SUKU and translated as "door-pole" by E. Speiser in Journal of Cuneiform Studies II (1948) 225ff. As against this correspondence we should note that the expected form in Old Akkadian should be su-ku-e not šu-ga-e.

Line 17.-GIŠ.ŠE.Ù TUR occurs also in no. 33:12, q.v.

Line 18.- The signs IÀ ù á-si-su are fairly clear. But how are they to be translated-"oil and its ašium?" 
Line 20.-The first word can be read as $z a / a / e-b \imath / n e / d \grave{e}-l u$. Could the second word be a defective $\mathrm{DUN}_{4}$ or SUUDUN? Some similar but not identical forms appear in texts of the Third Dynasty of Ur; see Schneider, Die Keilschriftzeichen der Wirtschaftsurkunden von Ur III (Roma, 1935) no. 185. Cf. also the use of the verb ZBL with tupšikkum in Delitzsch, $A H W B$ p. $250 \mathrm{~b}$. 


\section{4 (FM 229213)}

List of provisions and various objects and materials or a school tablet. The tablet is difficult to interpret.

\begin{tabular}{|c|c|c|}
\hline \multicolumn{3}{|c|}{ Transliteration and TRAanslation } \\
\hline Obv. 1) & ŠE.NUMUN & Seed barley \\
\hline 2) & $P \grave{u}-p \grave{u}$ & Bubu \\
\hline 3) & SIMUG & the smith (and) \\
\hline 4) & EDIN & EDIN. \\
\hline 5) & KUŠ.ŠUHUUB & Leather sandal(s) \\
\hline 6) & tab-ri-um IGI PA.AL É & $\begin{array}{l}\text {. . . of the ŠABRA-official of } \\
\text { the estate, }\end{array}$ \\
\hline 7) & $\begin{array}{l}\text { tab-ri-um IGI AB+ÁS̆ } \\
\mathrm{URU}^{\mathrm{KI}}\end{array}$ & $\ldots$ of the elder of the city, \\
\hline 8) & $\begin{array}{l}\text { KUG.GI KUG. } \\
\text { BABBAR }\end{array}$ & gold, silver, \\
\hline Rev. 9) & ŠE.NUMUN & seed barley, \\
\hline 10$)$ & $i \check{s}^{-} \mathrm{g} i_{4}{ }^{\top}-u m$ & (an object of wood) \\
\hline 11) & $\hat{E} \breve{s}-r a$ & Ešra \\
\hline 12) & AŠGAB & the leather worker. \\
\hline 13) & ŠE.BA É & $\begin{array}{l}\text { The barley allotment of the } \\
\text { estate. }\end{array}$ \\
\hline 14) & ŠE.NUMUN & Seed barley \\
\hline 15) & $A$-mur-DINGIR & Amur-ilum. \\
\hline 16) & $M U N$ & Salt. \\
\hline L.E. 17) & $S I G_{4}$ & Bricks. \\
\hline
\end{tabular}

\section{NOTES}

Line 4.-EDIN is evidently a personal name in view of the

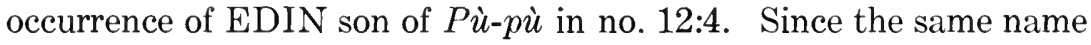
is mentioned in our text directly after $P \grave{u}$-p $\dot{u}$, it is possible that both tablets refer to the same persons.

Lines $6 f$.-The exact translation of tab-ri-um (also perhaps in no. 48:8) is unknown to me. ŠI may be interpreted as a genitive of $\check{u} u$ or as IGI, "in front." Could tab-ri-um be simply a personal name? Is line 7 a scribal correction of line 6 ?

Line 10. - Our $i \check{s}-{ }^{\top} g i_{4}{ }^{\top}-u m$ probably corresponds to GIŠ $i s ̌-g i_{4}-u[m]$ $L I \check{S}$ in an Ur III text transliterated in De Genouillac, ITT II 4646 rev. 6. But cf. also 1 TÚG.BAR.DÍB IŠ.GI $I_{4}$ in Thureau-Dangin, RTC 203:4. 

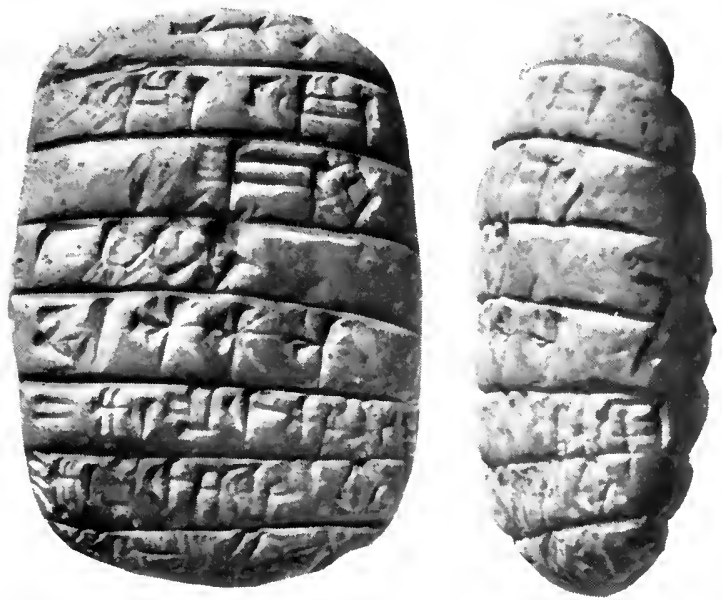

Obverse

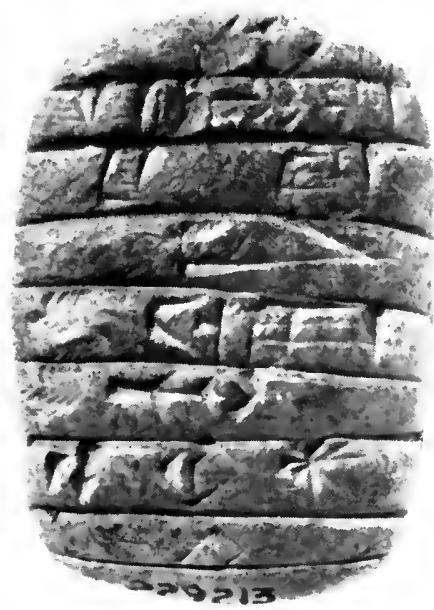

Reverse

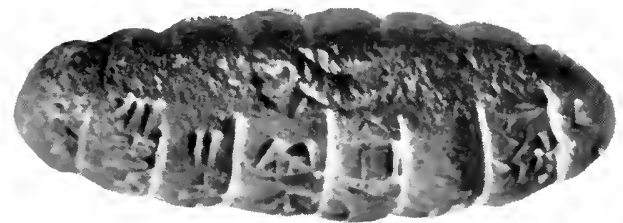

Left Edge

TABLET 44 (FM 229213) 


\section{5 (FM 229225+229229)}

Tablet badly preserved. Only some personal names are understandable.
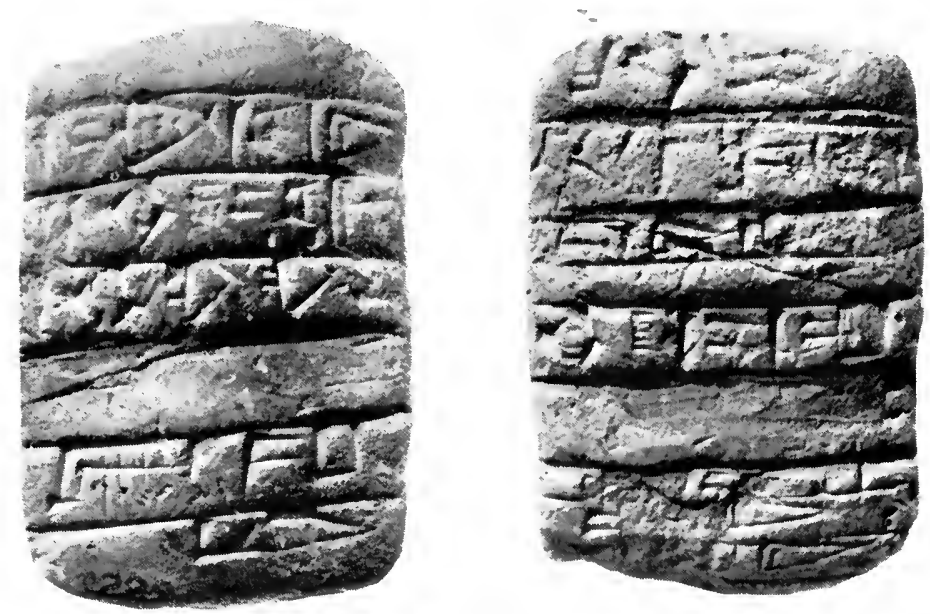

Obverse

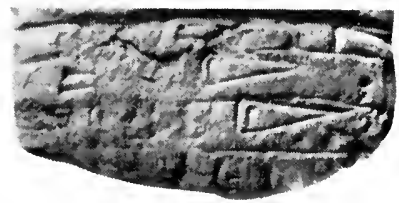

Reverse

TABLET 45 (FM 229225+229229)

TRANSLITERATION

Obv. 1) [....]

2) DUMU ARÁD-zu-ni

3) $a-n a I-s u-G I$

4) $a-n a$ GUD.GUD (space)

5) GÍN URUDU

6) AS̆GAB
Rev. 7) $\check{u} u-u t S I G_{4}$
8) ...
9) $D a-n i-a$ (space)
10) Na-bi-um (space)
11) ....-zu
12) Tab-ni
13) ....-ni
14) $\ldots .-i b$ 


\section{6 (FM 229240)}

The tablet is badly written. It was obviously composed by a scribe whose knowledge of cuneiform writing was inadequate.

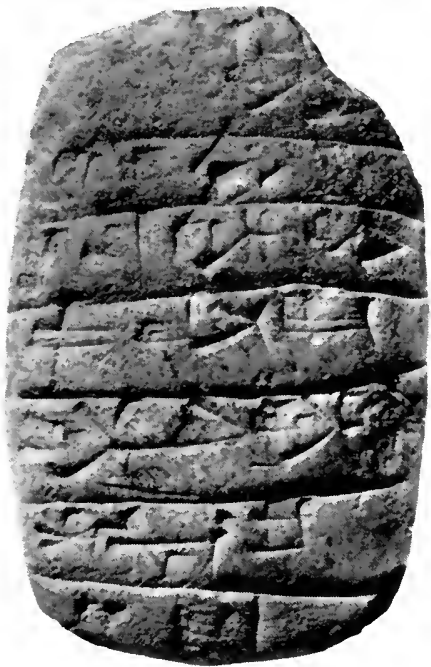

Obverse

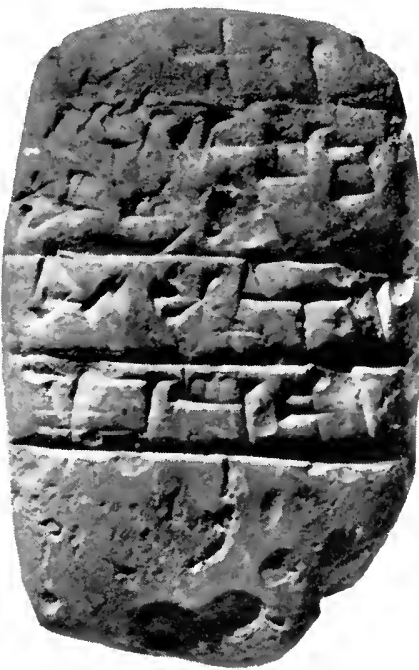

Reverse

TABLET 46 (FM 229240)

TrANSLITERATION

Obv. 1) $K A \check{S}$ šu si-[im]-tim

2) ù PA.TE.SI

3) šu si-im-tim

4) PA.AL É

5) $K A \breve{S}$ LÚ ...

6) ${ }^{\mathrm{d}}$ INNIN-GUR

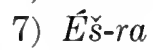

Rev. 8) ŠE. $H U$

9) KUG.BABBAR ù si-im-tim

10) GEMÉ- ${ }^{d}$ Innin

11) IŠ.NUN.GUR 


\section{7 (FM 229217)}

Obverse almost completely destroyed; reverse mostly preserved, but the sense of the inscription is elusive.

\section{Transliteration and Translation}

Obv. 1) IÀ. ${ }^{\top} G I S^{1}$

2) ZÍD.ÁŠ́.AN

3) $[\ldots]$

4) $[\ldots]$ ?

5) DIN[GIR-....]

6) en-ma

Rev. 7) $a-n a Z u-z u$

8) $a-n a \breve{\mathrm{S}} \mathrm{E}$

9) $\mathrm{UKU}_{\mathrm{x}} \cdot \mathrm{US}$

10) $a-n a \mathrm{AB}+\overline{\mathrm{A}} \check{\mathrm{S}}$

11) $g u-d u-s i-i \check{s}$

12) GIĽ.NI ki-ti-i[m]

13) GIŠ.NI
[Sesame] oil, emmer flour, $[\ldots]$

$[\ldots] ?$ Ilu[m-....] (said)

thus

to Zuzu:

For barley

of the soldiers

to the witnesses

in order to make sacred

carded wool.

\section{Notes}

Line 2.-For ZÍD.ẢŠ.AN, “emmer flour," see also Meek, HSS X 56, 57, etc., and for references to emmer, Deimel, $\check{S} L$ II 339:22 and 55 .

Line 9.--The first sign in UKU $U_{\mathrm{x}}$.UŠ is the GIN sign as it is usually written in texts of this period. See also no. 52:4 and the note in Deimel, $\breve{S} L$ II 348:1.

Line 11.--Interesting is the form $g u$-du-si-iš $=q u d d u s ̌ i s ̌$, "to make holy, sacred," identical in formation with hussusiš on another Old Akkadian tablet published in Meek, HSS X 197:13 and discussed by Meek in $R A$ XXXIV 66.

Line 13.-For GIŠ.NI = pušikkum, some kind of wool, see Deimel, $\check{S} L$ II 296:75d. This logogram occurs in connection with SíG, "wool," in an Old Akkadian text, Scheil and Legrain, Mém. XIV 7:3 and 5. The word pušikkum is also written with the Sumerian logogram SÍG.GA.ZUM.AG.A, which means "carded wool," that is, "wool which has been cleansed with a comb." See especially Deimel, $\breve{S} L$ II 319:98 and 539:66a; Meissner in AOF V $(1928 / 29)$ 184, n. 1 ; idem, $A S$ no. 1, p. 54, n. 1; Jacobsen in AJSL LV (1938) 


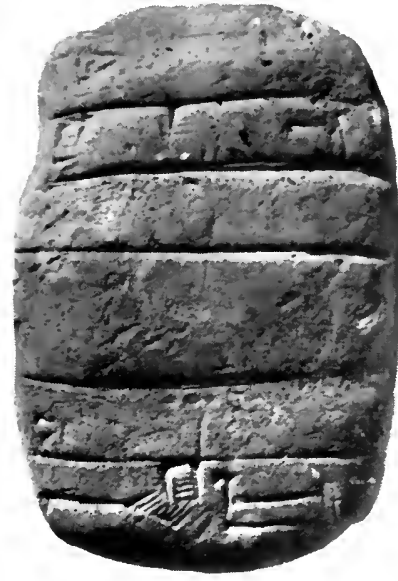

Obverse
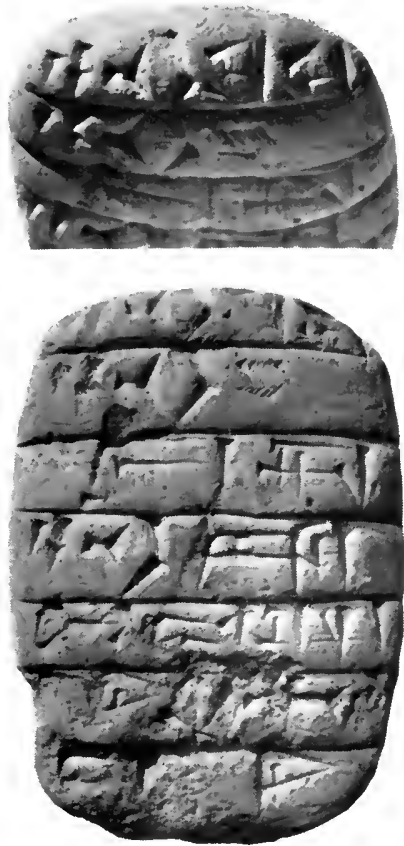

Reverse

TABLET 47 (FM 229217)

421. A picture of an Egyptian comb used for the purpose of separating and cleansing vegetable fibers or wool is shown in Lutz, Textiles and Costumes among the Peoples of the Near East (Leipzig, 1923) p. 17. 


\section{8 (FM 229223)}

The tablet is very badly preserved and only a word here and there can be deciphered and understood.

\section{Transliteration}

(1 line erased?)

Obv. 1) Li-bur

2) A ̌sGAB

3) 'in' KUŠ.A.GÁ

4) NINDA IÀ

5) ZÍD.GÚG

6) 'in' KUŠ.A.GÁ

7) $B e-l i-. .$.

\author{
Rev. 8) 'tab-ri`-um \\ 9) 'É'.MUHALDIM \\ 10) ....-at $\breve{\mathrm{S}} \mathrm{E}$ \\ 11) $\check{S} E[1] \mathrm{i} / \check{\text { saa-si }}$ \\ (space) \\ 12) .... \\ L.E. 13) TÚG $g u-z i-t i$-[im]
}

\section{Notes}

Line 3.- On the logogram KUŠ.A.GÁ here and in line 6 see n. to no. $34: 4$.

Line 5.-The logogram GÚG expresses some legume, the specific type of which is unknown. On it, as well as on ZIID.GUGG, "flour of GÚG," found for example in $C T$ X 21 iv 14, see Deimel, $\breve{S} L$ II 345:5.

Line 13.-The reconstruction of this line is not sure. See note on kusîtum, discussed under no. 7:3. 

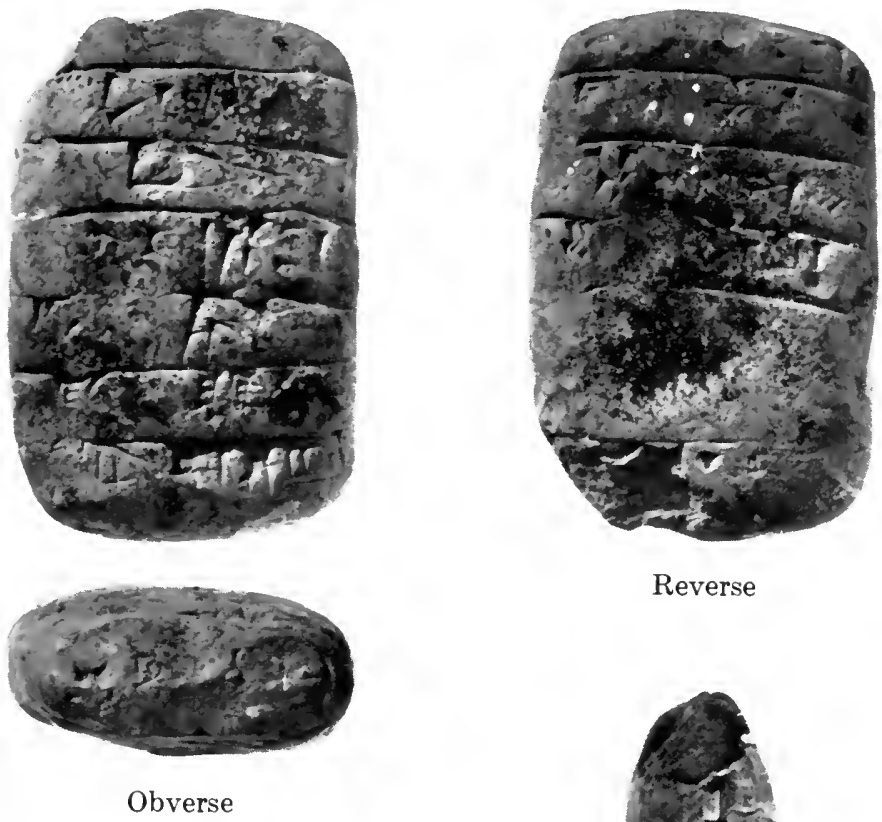

Reverse

TABLET 48 (FM 229223)

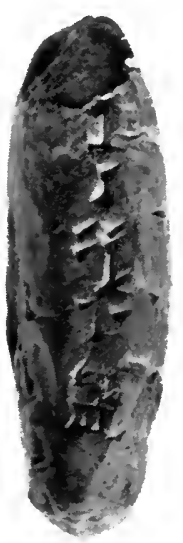

Left Edge 
49 (FM 229203)

Since the inscription is incompletely preserved its character cannot be defined. The preserved parts contain only personal names. The first two women named are defined as $r u-k u$-ma-um in line 5. The word rugummāa um, sing. in the collective sense, from the root RGM, "to claim (legally)," evidently indicates that the women had been or were to be claimed through a juridical process. This word, as well as such comparable forms as muhurrā'um and huluqqāam from the Old Akkadian tablets published in $M A D$ I $21,268,275$, and 323 , was recently studied by Poebel, $A S$ no. 9, pp. xif. A larger study on nouns of this formation was written by von Soden, "Nominalformen und juristische Begriffsbildung im Akkadischen: Die Nominalform "qutullā’," Symbolae Paulo Koschaker dedicatae (Leiden, 1939) pp. 199-207, with additions in Orientalia n. s. XV (1946) 423-426. His assumption, however, that the formation is of late date in Akkadian is contradicted by the existence of the Old Akkadian forms in the tablets cited above.

\section{Transliteration}

Obv. 1) $<1>T a-t a$

2) DUMU.SAL $I \check{s}-b u-a$

3) 1 ME-İr-ra

4) DUMU.SAL Da-KA-KA

5) $r u-k u-m a-u m$ (double line)

6) 1 Li-pù-ru-um

7) $1 E \check{s}_{4}-d a r-B A L A G$

8) 1 Gi-nu-nu

9) 1 Ar-ku-ku

10) 1 KUG.BABBAR-sa

11) $1 \grave{I}-l u-l u$

12) [1] $I-l u-d a m-k u$

13) 1 ARÁD-zu-ni (erasure) (about 1-3 lines missing)

Rev. (beginning destroyed) (large space)

$\mathrm{x}+1)$ 1 I-da-ra-a[k]

$\mathrm{x}+2)$ DUMU Um-[....]

$\mathrm{x}+3) \quad s a-t i-d a g[u]-z i-[\mathrm{im}]$ 


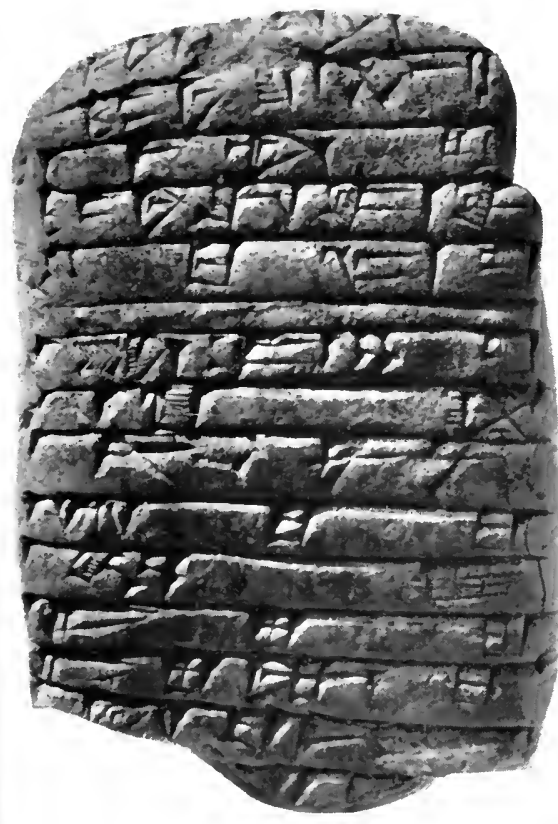

Obverse

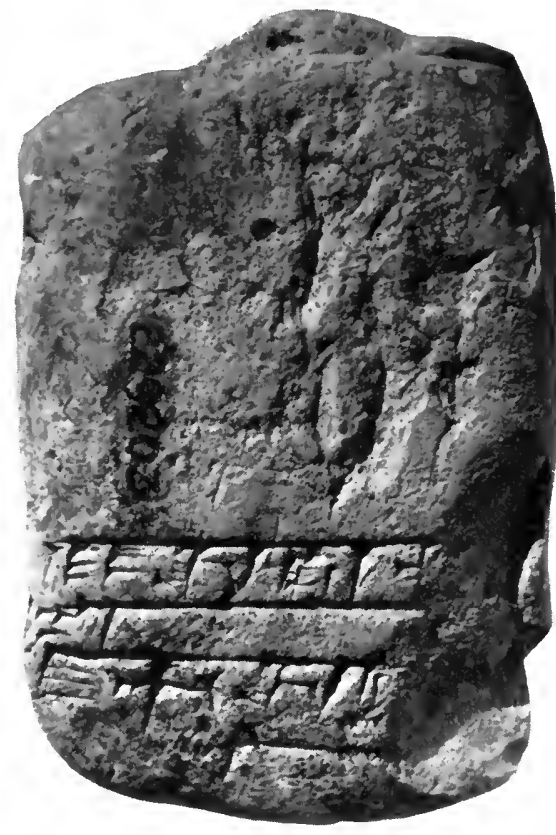

Reverse

TABLET 49 (FM 229203)

\section{NOTES}

Line 12.-The name $I-l u-d a m-k u$ occurs also elsewhere, for example, in the Old Akkadian tablets cited in MAD I p. 204, and is parallel in its formation to $\bar{I}-l u-d a-n u$ (ibid.). Since the name $\bar{I}-l u-d a m-k u$ can hardly be interpreted as Ilū-damqū, "the gods are good," because such formations in the plur. are unattested in Akkadian onomastic practice, we should probably take $I-l u-d a m-k u$ as Ilum-damqum, "good god." These two names, just like Da-lim (no. 6:1), En-na-nu (no. 23:5), and $A$-h̆u-li-bur-ra (no. 28:4), lack mimation; since mimation is regularly preserved in the Old Akkadian period, the names must be considered as archaisms from a period in which mimation had not yet been developed. See also the $n$. to no. 8:12.

Rev. line $x+3 .-$ This line is too broken to allow of any safe reconstruction. The possibilities are $s a-t i-d a g[u]-z i$ - $[i m]$ or $g[u]-z i-$ [ti-im] "(2 men), the measurers (dual) of the chair" (kussi um) or "of the garment" (kusîtum). 


\title{
50 (FM 229247)
}

The half of the tablet which contains personal names is well preserved; the other half is mostly destroyed.

\section{TRANSLITERATIOON}

\author{
Obv. 1) Du-ma-ga \\ 2) $U m-m i-E \check{s}_{4}-d a r$ \\ 3) $E \check{s}_{4}-d a r-\mathrm{MI}$ \\ 4) Dar-e-tum \\ 5) Bí-láa $M U \check{S} E N .[D U ̃]$ \\ 6) $L a ́$-wi-ip-tum \\ 7) $W a-z u-z u$ \\ 8) $\mathrm{Zu}-\mathrm{zu}$ \\ 9) Gur-bi-bi \\ 10) $\bar{I}-l i ́-a-b i$ \\ Rev. 11) Da-ad-lul-tum \\ (rest almost entirely destroyed)
}

\section{Notes}

Line 1.-The personal name $D u$-ma-ga is identical with $D u-m a$ qum on a seal published by C. H. Gordon in Iraq VI pl. III, no. 12. On the $-a$ ending see $n$. to no. 25:2.

Line 11.-The personal name Da-ad-lul-tum occurs in Meek, $H S S \mathrm{X}$ p. xxix and frequently in $M A D$ I p. 187. 


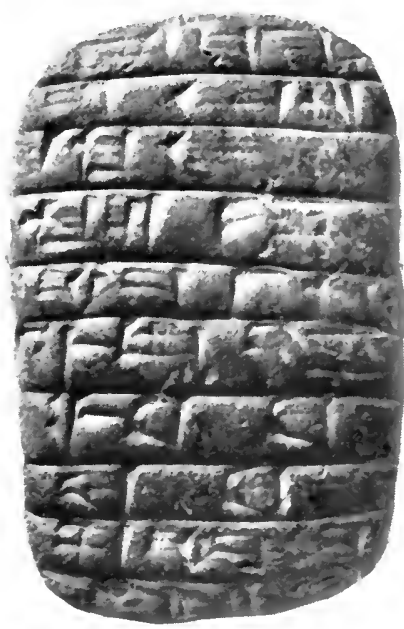

Obverse

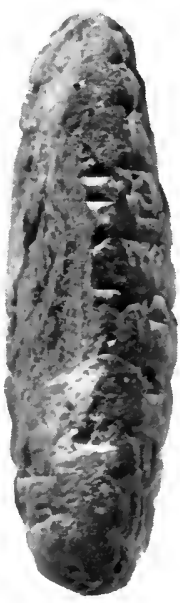

Left Edge
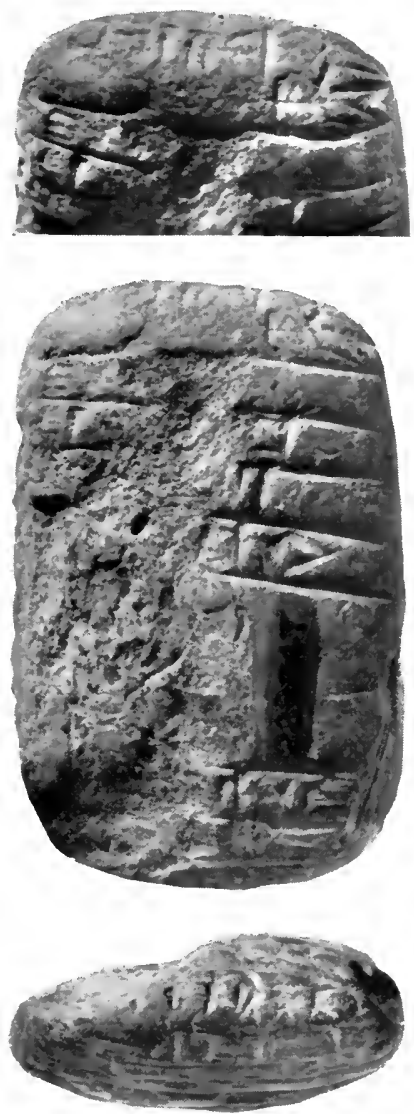

Reverse

TABLET 50 (FM 229247) 


\section{1 (FM 229244)}

Flaked-off fragments of a tablet with the major part of the reverse preserved.

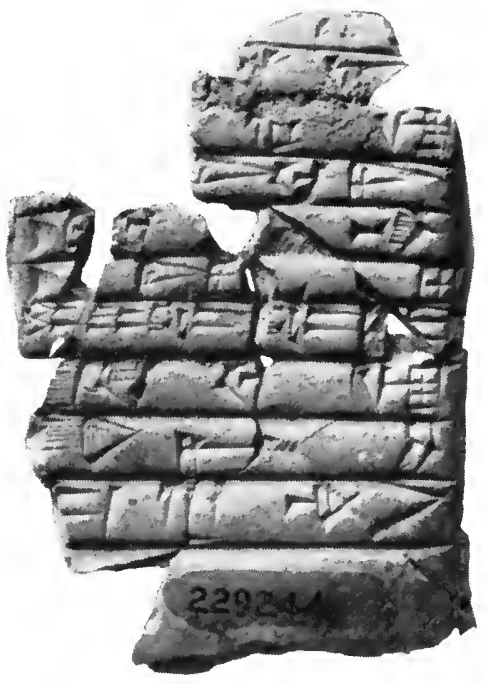

Reverse
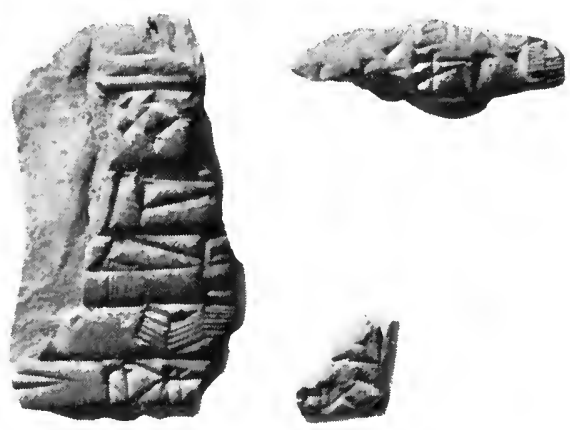

Fragments

TABLET 51 (FM 229244)

\section{Transliteration}

(Obverse destroyed)

$$
\begin{aligned}
& \text { Rev. } \mathrm{x}+1)[\ldots \mathrm{PA}] \cdot \mathrm{RIM}_{4} \\
& \mathrm{x}+2)[\mathrm{KÁ}]{ }^{\mathrm{d}} \text { Tišpak } \\
& \mathrm{x}+3)[i t]-m \dot{a}-\grave{u} \\
& \mathrm{x}+4)[1 \quad \grave{I}]-l i-b a-n i \\
& \mathrm{x}+5) 1 L[u]-b a-[\mathrm{x}]-n a \\
& \mathrm{x}+6) 1 \grave{I}-l u-l u \\
& \left.\mathrm{x}+7) \text { DUMU I-bi-bi SAG.ZU[G } \mathrm{G}_{7}\right] \\
& \mathrm{x}+8)[D] a r-s u-b a \dot{u} \\
& \mathrm{x}+9) g a-z i-r u \\
& \mathrm{x}+10)[M] a-m a ́-t i m
\end{aligned}
$$




\section{Notes}

Lines $x+2 f$. - - The reconstruction of these lines is based on comparison with $\mathrm{KA}{ }^{\mathrm{d}}$ Tišpak it-ma, "he swore in the gate of Tišpak," in no. 7:26. The plur. form $i \operatorname{tma}^{\prime} \bar{u}$ is found in another Old Akkadian text published in Scheil and Legrain, Mém. XIV 44 rev. 6: ni-išs LUGAL . . . [i]t-ma-ì, "they swore by the king."

Line $x+5$.- The sign $L[u]$ is almost sure. Between $b a$ and $n a$ there is a break, with room for possibly one sign, but perhaps nothing is missing, and the whole name is $L[u]-b a-n a$, comparable with Lú-ba-na in Meek, HSS X 153 iii 20, which contains the element $b a-n a$, as in DINGIR-ba-na, $A-b i-b a-n a^{\mathrm{KI}}$ (cited in Ungnad, $M V A G$ XX 2, pp. 47f.), etc. This form will be discussed in the near future.

Line $x+7$.-The SAG.ZUG ${ }_{7}$ official, Akkadian šassukkum, called "the scribe of the fields," had charge of the land register. See von Soden in ZA XLI 233-236.

Lines $x+8 f f$. - The interpretation of these three lines as " $[D]$ aršuba and the fullers of Mamatum" seems plausible. The name Daršuba is unknown to me. The personal name Ma-ma-tum occurs in Scheil and Legrain, Mém. XIV 40:8; 71 rev. i 8; Meek, HSS X 188 iv 3. Our writing $[M] a-m a$-tim with the MÁ sign presupposes length or some similar feature, as in the common writing Iš-má-DINGIR in the Old Akkadian period. 


\section{2 (FM 229252)}

A well-preserved letter from Ginunu to Ilī-ahì. If I understand the text correctly, Ginunu is complaining about the fact that Ilī-ahi has stopped sending bread for the soldiers, and then asks him whether he needs certain items expressed by two words which I do not understand. Perhaps they are ingredients used in making bread.

The use of double consonants in the words su-tu-uh-ha-tim in line 6 and te-er-ri-iš in line 8 is rather unusual for this period. Were it not for the fact that Ginunu is mentioned in this tablet (on this individual see above, p. 173), one would be inclined to consider the possibility that this tablet comes from a later period or from a different region, in which the custom of writing double consonants was developed earlier than in the Diyala region (see also above p. 179).

\section{Transliteration AND TRANSLATION}

Obv. 1) en-ma

2) Gi-nu-nu

3) $a-n a \dot{I}-l i-a-h i$

4) NINDA UKU $U_{x} \cdot U S$

5) mi-num da-ap-ru-us

Rev. 6) su-tu-uh-ha-tim

7) $\grave{u}-l u k i-s a-m a-r i$

8) $t e-e r-r i-i \check{s}$
Thus (says)

Ginunu

to Ilì-ahì:

Bread of the soldiers

why did you deny (withhold)

(and) the ....

or the ....

(why) do you request?

\section{Notes}

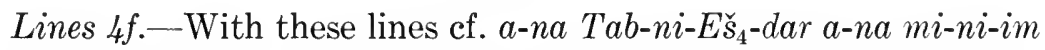
$i$-bi-ir-ša ta-ap-ru-za, "why did you deny the food to Tabnî-Eštar?," in an Old Babylonian letter published in CT XXIX 1a 15-18, and translated by Ungnad, $B B$ no. 96 . On the word mi-num, "why," ef. mi-núm ù-la $a$-bi $a d-d a$, "why are you not my father?," in L. C. Watelin and S. Langdon, Excavations at Kish III (Paris, 1930) pl. XI W. 1929, 160:4ff.

Lines 6f.- In spite of diligent search I have not been able to find any parallels to the words $s u$-tu-uh-ha-tim in line 6 and $k i$-sa$m a-r i$ in line 7 . The first word seems to be a noun formed on the root $\breve{S_{7}}{ }_{7} \mathrm{H}$, "to grow"; the second may possibly be gišimmaru, "date (palm)," but this cannot be proved. The possibility of reading the first word as ${ }^{\mathrm{KUS}} t u-u h$-ha-tim or sud/t/tuh hattim should also be considered. 

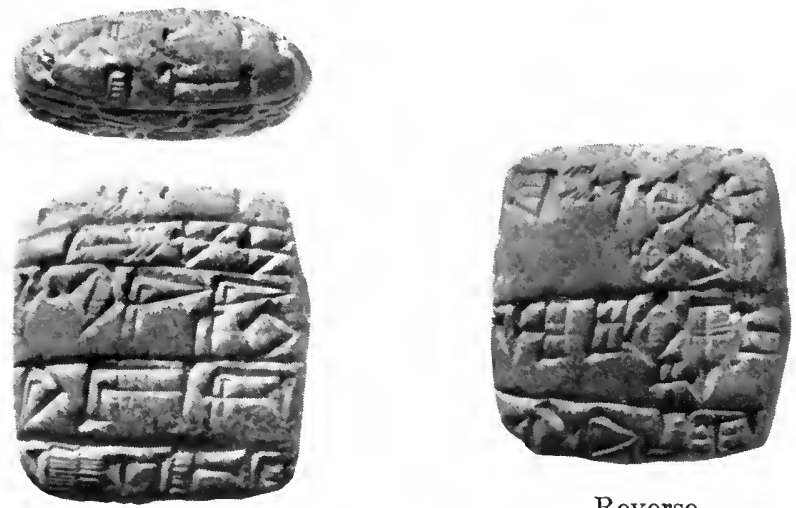

Reverse

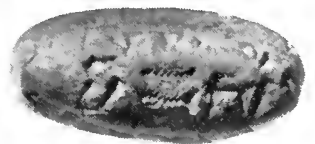

Obverse

TABLET 52 (FM 229252) 


\section{3 (FM 229253)}

This is a puzzling letter owing partly to its bad preservation and partly to the internal textual difficulties which it presents. The translation below is offered with due reservations.

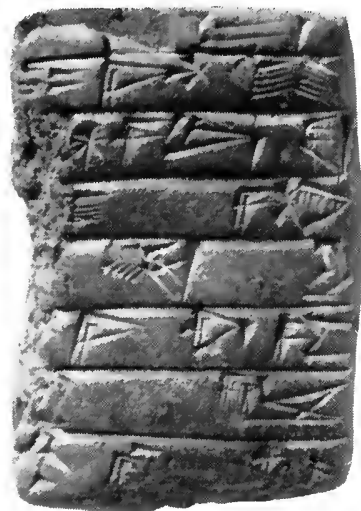

Obverse

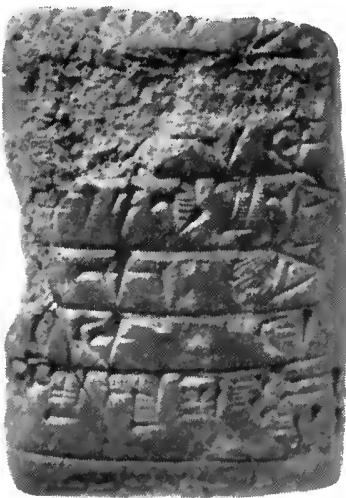

Reverse

TABLET 53 (FM 229253)

\section{Transliteration and Translation}

Obv. 1) 'en

2) I-gu-núm

3) $[a-n] a$ DINGIR-al-su

4) $[\mathrm{m}] \mathrm{i}-\mathrm{s} u m$

5) $[a ́ a s ̌ s-t u-r u$

6) ' 'a'-ni-ir-kum

7) ' ${ }^{\top} i^{\top}$-tum

8) ha-ra-nam

Rev. 9) $a-h u-z[a-a] m$

10) $[\ldots]$. .

11) $[\ldots-d] a-b a$

12) GÁN $a-n a S u_{4}-b e-l \hat{n}$

13) $[i]-t i-i n$

14) ZÍD.BA-su

15) $\grave{u}-l a e-b i-i \check{s}$
Thus (says)

Ikûnum

to Ilum-alšu:

As

I wrote,

I killed (the animals) for you. (As for) the rest, the road

I took

....

the field to Šu-bêlī

[he] gave

(and) his flour ration he cannot make. 


\section{Notes}

Line 4.--Although the first sign is partly destroyed, its reading is relatively sure. The word mišum with the meaning "why" is frequently found in Cappadocian in interrogative clauses. In our text, in view of the subjunctive form $[\dot{a}]]_{s}-t u-r u$, an indefinite meaning, "whatever" or the like, seems more appropriate. On mišum cf. the discussion by von Soden in ZA XLI $114 \mathrm{f}$.

Line 14.- The reading of the signs is clearly ZÍD.BA, which must mean "flour ration." The word is not attested elsewhere. For TÚG.BA beside ŠE.BA, IÀ.BA, and SÍG.BA see Delitzsch, Sumerisches Glossar (Leipzig, 1914), p. 60.

Line 15. - The form $e-b i$-iš in our tablet corresponds to the commonly used present form ippiš of the Old Babylonian period. See the examples in J. Kohler and A. Ungnad, Hammurabi's Gesetz II 121; Ungnad, $B B$ p. 267; and elsewhere. Several occurrences of $i$-pi-eš, $i$-pi-šu, etc. are found also in Poebel, PBS V 142 rev. ii. Thus Old Akkadian and Old Babylonian pret. îpuš, pres. i/eppǐs corresponds to later Babylonian îpuš, ippǔs, and to Assyrian êpǔs, eppaš. Ungnad's derivation of eppiš (really eppeš in his opinion) from eppaš (Babylonisch-assyrische Grammatik; [2d ed.; München, $1926] \S 47 f$ ) is unnecessary. 


\section{Indices of Proper Names}

\section{PERSONAL NAMES}

The personal names are arranged in the order of the Latin alphabet. The logograms in Akkadian names have not been transliterated into Akkadian but retained in their Sumerian form in harmony with their treatment in the main part of this study.

The following abbreviations for genealogical relationships are used in the list: s. for son, gs. for grandson, f. for father, gf. for grandfather, d. for daughter, br. for brother, h. for husband, and w. for wife.

The paternal relationship is normally described by the phrase A DUMU B, "A son of B," as in Ma-šum DUMU Maš-tum (no. 3:5f.), or by A DUMU B DUMU C, "A son of B, (who is) the son of C," as in DINGIR-na-zi-ir DUMU KA-Me-ir DUMU İ-me-Dur-ùl (no. 9:3ff.). But often, though less frequently, we find the phrase A šu B, "A he of B," as in E-gi šu Tab-si-ga (no. 3:1f. and similarly nos. 7:28f.; 25:7f.), or the hybrid phrase A DUMU B š $i$ C, "A son of B, (who is) of C," as in EDIN DUMU Pù-pù ši UR.UR (no. 12:4f. and similarly no. 9:6ff.). From the interchange of $\check{S} u$-i-li-su DUMU $M u-m u$ (occurring three times) with $\breve{S} u-i-l i-s u$ šu $M u-m u$ (occurring once), Meek, HSS X p. xv, drew the conclusion that both DUMU and $\check{s} u$ mean "son (of)." A careful consideration of the extensive evidence provided by the Diyala texts and the Maništušu Obelisk makes Meek's conclusion untenable. In a study soon to be published I hope to be able to prove that šu "he (of somebody)" expresses not a paternal relationship but an affiliation to a clan organization.

The personal names are often preceded by the number 1 , which in the later period developed into the determinative for masculine personal names. In the Old Akkadian period this number was used before both masculine and feminine names, with the result that it is often difficult to ascertain the gender of some of the names. Use of the number in front of the names was not obligatory. This is best proved by no. 14, in which some of the names are accompanied 
by the number and others are not. This determinative appears most commonly in front of the names in lists, as in lists of workers, witnesses, etc.

Almost all the personal names in our list are Akkadian. Their formation is identical with or similar to that of the names used in other areas where Akkadians lived in this period. Sumerian names, such as Ur-Šudda or Ua, are very rare. Interesting and important is the total lack of non-Akkadian and non-Sumerian names in the collection. One name that at present defies all interpretation is Lu-ga-lu-mu-uk (no. 31:5).

A great number of names exhibit reduplication of the type discussed by Meek in his article "The Iterative Names in the Old Akkadian Texts from Nuzi," $R A$ XXXII (1935) 51-55. We have in our texts names that are fully reduplicated, such as Bubu, Dada, Dudu, Gugu, Lili, Tata, Zeze, Zuzu, as well as names that have the second part reduplicated, such as Abibi, Agaga, Agigi, Alili, Allulu, Arkuku, Ašaša, Atiti, Bašušu, Dabubu, Edada, Enana, Eruru, Ezeze, Ginunu, Gurbibi, Ibibi, Ibbubu, Ilala, Ilili, Ilulu, Išaša, Izaza, Kizaza, Manunu, Mututu, Ummimi, Wazuzu.

Hypocoristica ending in $-a$ (or $-j a$ ), so frequent in later periods, occur only in $D a-n i-a, E-s i-a$, and $I \check{s}-b u-a$. Unique is the short form $D a-b i$-lum for $I-d a-b i$-i-li (both in no. 2).

Other features of the personal names are discussed elsewhere: archaisms, such as Amassuni and Warassuni, under no. 8:12; names without mimation under no. 49:12; ending - $a$ under no. 25:2; ending -iš under no. 16:3; DAM corresponding to "Mrs." under no. 16:1; TUR meaning "Jr." under no. 33:47; declension of names under no. $30: 5$.

$\mathrm{AB}+\hat{\mathrm{A}} \breve{\mathrm{S}}$, perhaps not a name

1) No. $47: 10$

$\mathrm{AB}+\overline{\mathrm{A}} \mathrm{S}$ URU ${ }^{\mathrm{KI}}$, perhaps not a name

1) Nos. $17: 16 ; 19: 16 ; 44: 7$

2) E-ru-ru šu $\mathrm{AB}+\overline{\mathrm{A}} \breve{\mathrm{S}}$ A-bí-bi $\mathrm{URU}^{\mathrm{KI}}$, no. $7: 29$

1) No. $30: 7$

2) X, no. $2: 8$

3) br. of NU.BANDA, no. $13: 3$
A-dam-u

1) No. $5: 10$

2) s. of $P \grave{u}-\grave{i}-l \grave{l}$, no. 8:1

Ad-mar

1) No. $39: 6$

A-ga-ga

1) No. $33: 26$

A-gi-gi

1) No. $20: 8$

A-ha-KUG.BABBAR-sa

1) No. $28: 7$ 
A-hu-li-bur-ra

1) No. $28: 4$

A-li-li

1) Nos. $15: 4 ; 33: 30$

2) ŠEŠ.SAL $A$-bi-bi, no. $30: 6$ Al-i-lí

1) s. of $S u-b a-\grave{e}$, no. 8:2 [A]l-lu-lu

1) No. $25: 4$

Al-lum

2) f. of $\check{S} u-N a-n a$, no. $9: 2$ AMA-Ga-zur $(\mathrm{SAG})$

1) No. $20: 2$

A-ma-rí-ǐs

1) TÚG, no. $16: 7$

AMA.TU

1) 'UGULA' NAGAR, f. of $I-z u-u r-b a-s[u]$, no. $39: 11$ A-mur-DINGIR

1) No. $44: 15$

A-nin-u

1) s. of . . . .-na-bí, no. 18:20 ARÁD- ${ }^{\mathrm{d}}$ Innin

1) Nos. $3: 4 ; 11: 4$

ARÁD- ${ }^{\mathrm{d}}$ Tišpak

1) No. $13: 2$

'ARÁD'-Tu-tu

1) s. of Be-li-GUR ${ }_{7}$, no. $4: 12$ ARĀD-zu-ni

1) Nos. $8: 12 ; 11: 1 ; 17: 3 ; 18: 11$; $19: 4 ; 27: 1 ; 37: 7 ; 45: 2 ; 49: 13$ Ar-ku-ku

1) No. $49: 9$

Á-ru-kum

1) No. $25: 3$

$A$-ša-ša

1) Nos. $17: 7,13 ; 18: 7$; $19: 5,15$

$\bar{A} \check{s}$-ma-tum

1) No. $28: 2$
A-ti-e

1) Nos. $18: 9,18 ; 19: 12$ (written $A-t[i-e]$ ); 30:1

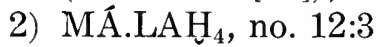
A-ti-ti

1) No. $33: 56$

$B a-l u-s a$

1) No. $33: 27$

$B a-n i$

1) UD.KA.BAR, no. $16: 8$, doubtful

Ba-pù-zum

1) No. 11:2

$B a-\mathrm{r}[\mathrm{i}-\mathrm{i}] \mathrm{s}-t u m$

1) No. $24 x+2$

$B a$-šu-šu, see also $W a-z u-z u$

1) No. $23: 9$

Be-lí

1) s. of $B u-b u$, no. $39: 8$ Be-lí-. . .

1) No. $48: 7$

Be-li-AN.DU்L

1) NAGAR ARÁD $D u-d u$, ši E-la-me-tum, no. 9:9 Be-lí-ba-ni

1) No. $2: 3$

$B e-1[1$-da-t]i

1) 'MUŠSN'.D广், f. of $E n$-[. . . .], no. 12:7

Be-lí-DÜG

1) No. $37: 15$

Be-li-GUR ${ }_{7}$

1) f. of 'ARÁD'-Tu-tu, no. $4: 13$

Be-lí-sa-tu

1) No. $9: 14$ Bí-láa

1) No. $23: 10$

2) $M U \check{S} E N .[D \grave{U}]$, no. $50: 5$ Bi-za-num

1) No. $36: 20,22$ 
$B u-b u, P \grave{u}-p \grave{u}$

1) SIMUG, no. 44:2 (written $P \grave{u}-p \grave{u})$

2) EDIN, s. of $P \grave{u}-p \grave{u}, \breve{s} i$ UR.UR, no. $12: 4$

3) f. of Be-li, no. 39:9 (written $B u$-bu)

4) f. of $I$-dur-GI, no. $12: 11$ (written $B u-b u$ )

Da-ad-lul-tum

1) No. 50:11

Da-bi-lum ( $=I-d a-b i-i-l i)$

1) No. $2: 16$

$D a-d a$

1) No. $22: 4$

2) w. of $\breve{S} u-a-t u m$, no. $20: 4$ Da-KA-KA

1) f. of ME-İr-ra, no. $49: 4$ Da-lim

1) UGULA URU, no. $6: 1$ Da-ni-a

1) Nos. $17: 14 ; 18: 17 ; 45: 9$

Dan-i-li

1) Nos. $1: 8 ; 8: 10,20$

Dar-e-tum

1) Nos. $3: 9 ; 50: 4$

[D]ar-su-ba

1) No. $51 \mathrm{x}+8$

Dar-u-ma

1) No. $15: 1$

DINGIR-, see also under $\grave{I}-l i$ DINGIR-... .

1) Nos. $36: 15 ; 47: 5$

DINGIR-al-su

1) No. $53: 3$

2) DI.TAR, no. $7: 27$

DINGIR- $a-z u$

1) No. $1: 11$

2) DAM.KÀR, no. $16: 4$

DINGIR-ba-ni

1) No. $14: 29$
DINGIR-dan

1) Nos. $4: 3 ; 5: 4 ; 33: 44$

2) $\check{u} u$ GUD.GUD PA.RIM ${ }_{4}$, no. $7: 28$

DINGIR-GI

1) Nos. $12: 12 ; 39: 7$

DINGIR-KÀR

1) f. of $E-d a-d a$, no. 8:7

DINGIR-na-zi-ir

1) No. $28: 3$

2) s. of KA-Me-ir, gs. of $\grave{I}-m e-D u r-\grave{u} l$, no. 9:3

DINGIR-SIPA

1) NAGAR ARÁD-d Tišpak, no. $13: 1$

DINGIR-UR.SAG

1) s. of $\breve{S} u-M a-m a$, no. $12: 8$ $D u-d u$

1) Be-lí-AN.DÙL, NAGAR ARÁD $D u-d u$, ši E-lame-tum, no. $9: 10$

Du-gul-tum

1) No. $33: 21$

Du-ma-ga

1) No. $50: 1$

DUN.Ú

1) ARÁD $S a-a-m i$-išs, no. $16: 2$

$\hat{E}-a-i-l i$

1) No. $1: 7$

E-da-da

1) s. of DINGIR-KÀR, no. $8: 6$

EDIN

1) No. $44: 4$

2) s. of $P \grave{u}-p \grave{u}, \check{s} i$ UR.UR, no. $12: 4$

E-gi

1) $T a b-s i-g a$, no. $3: 1$ É.GI.A

1) No. $20: 9$ 
E-la-me-tum

1) Be-li-AN.DÜL, NAGAR ARĀD $D u-d u, \check{s} i E-l a-$ me-tum, no. 9:10

E-lu-sa

1) No. $28: 9$

En-[....]

1) s. of $B e-$-l[í-da-t]i ' $M U \breve{S} E N$ '. DU, no. $12: 6$

E-nam-ra

1) No. $1: 4$

E-na-na

1) No. $36: 4$

E-ni-um, I-ni-um

1) No. 36:6 (written $\dot{E}-n i-u m$ )

2) $I-g u-n u ́ m$, [s. of] $I-n i-u m$, no. $4: 7 ; I-{ }^{-} g u^{1}-n u m$, s. of $\grave{E}-[n] i-u m$, no. $7: 30$

En-na-nu

1) No. $23: 5$

En-ni-li

1) No. $33: 60$

E-ru-ru

1) $\check{u} u \mathrm{AB}+\check{A} \check{S} \mathrm{URU}^{\mathrm{KI}}$, no. 7:29

$E \check{s}_{4}-d a r-\ldots$.

1) No. $28: 1$

$E \check{s}_{4}-d a r-a l-s u$

1) SIPA UDU, no. $16: 5$

$E \check{s}_{4}$-dar-BALAG

1) No. $49: 7$

Es. $\check{s}_{4}$-dar-dam-ga-at

1) Nos. 28:5; 30:2

$E \check{s}_{4}-d a r-d a-r i$

1) No. $33: 29$

$E \check{s}_{4}-d a r-d u$-gul-t[i]

1) Nos. 19:18;30:9 (written $\left.E \check{s}_{4}-d a r-d u-[g u] l-t i\right)$

$E \check{S}_{4}-d a r-G A L$

1) Nos. $19: 17 ; 30: 3$ (written $\left.E \check{s}_{4}-d a r-r a-b i-a t\right)$
$E \check{s}_{4}-d a r-i-m i-t i$

1) No. $23: 3$

Ešs

1) Nos. $23: 6 ; 50: 3$

$E \check{s}_{4}-d a r-s a-t u$

1) No. $3: 3$

$E \check{s}_{4}$-dar-UR.SAG

1) Nos. $14: 16 ; 33: 51$

E-si-a

1) Nos. $17: 8 ; 18: 8 ; 19: 13$ Éšr $r a$

1) No. $46: 7$

2) AŠGAB, no. 44:11

EZEN, see also $\bar{I}-z i-n a$

1) No. $25: 2$

$E-z e ́-z e ́$

1) No. $33: 38$

Ga-li-ǐ̌-DÜG

1) No. $32: 3$

Gal-pum

1) s. of $S u$-ba-ri-im, no. $29: 1$

Ga-mi-ru-um

1) No. $16: 9$

GEME-. . .

1) No. $17: 15$

GEMÉ- Innin

1) Nos. $15: 5 ; 46: 10$

2) ŠU.I, no. $22: 1$

GEMÉ- $z u$

1) No. $6: 2$

GEME- $z u-n i$

1) Nos. $15: 2 ; 23: 4$

Gi-nu-nu

1) Nos. $3: 8 ; 8: 9 ; 9: 15 ; 10: 7$;

$11: 6 ; 12: 18$ (written

[Gi-nu]-nu); 14:3, 10;

37:14; 49:8; 52:2

[Gi-nu-u] š-sa-am

1) No. $9: 19$ 
$G i-s ̌ u m$

1) No. $7: 22,31$

GUD.GUD, see also following name

1) No. $45: 4$

2) DINGIR-dan, šu GUD. GUD PA.RIM 4 , no. 7:28

$G u-g u$, see also preceding name

1) TUR, no. $33: 47$

Gu-gu-za-núm

1) MUŠEN.DÜ, no. $12: 13$ Gur-bi-bi

1) No. $50: 9$

Hu-li-um

1) No. $1: 5$

Hu-ma-za

1) Nos. $14: 4 ; 20: 5$

$\mathrm{Hu}$-mi-zum

1) UH.ME, no. $8: 5$

$\mathrm{Hu}-n i-z u$

1) No. $27: 7$

$I b-b u-b u$

1) No. $3: 11$

$I-b i-b i$

1) No. $5: 9$

2) SAG.ZU[G $\left.\mathrm{G}_{7}\right]$, f. of $\grave{I}-l u-l u$, no. $51 \mathrm{x}+7$

$I-d a-b i-\hat{\imath}-l i(=D a-b i-l u m)$

1) No. $2: 2$

2) UGULA, no. 12:17

$I-d a-{ }^{\mathrm{d}} \mathrm{EN} . \mathrm{ZU}$

1) GAL.UKU, no. $12: 1$

I-da-ra-ak

1) No. 10:1

2) s. of $U m-[\ldots]$, no. 49 rev. $\mathrm{x}+1$

I-dur-GI

1) s. of $B u-b u$, no. $12: 10$

I-gi-ni

1) No. $5: 15$
I-gu-núm

1) Nos. $5: 5 ; 53: 2$

2) s. of $I-n i-u m$, no. $4: 6$; s. of $\grave{E}-[n] i-u m$, no. $7: 30$

I-la-la

1) Nos. $1: 6 ; 6: 6$

$\bar{I}-l i$-, see also under DINGIR$\bar{I}-l i-a-b i$

1) No. $50: 10$

$\grave{I}-l i-a-h i$

1) Nos. $8: 11,19 ; 27: 2 ; 52: 3$

I-li-ba-ni

1) No. $51 \mathrm{x}+4$

I-li-dan

1) No. $28: 6$

İ-li-DIRIG

1) No. 11:15

İ-li-GAL

1) SANGA, nos. $1: 1 ; 18: 19$

$I-l i-\imath \check{s}-d a-g a[l]$

1) NU.BANDA, no. $4: 11$

İ-li-kára-bí (preceded by DAM)

1) No. 16:1

I-li-lí

1) No. $37: 12$

İ-lí-sa-liq

1) No. $5: 6$

İ-lu-dam-ku

1) No. $49: 12$

'I'T-lul

1) No. $19: 2$

İ-lu-lu

1) Nos. $1: 3 ; 42: 6 ; 49: 11$

2) s. of $I-b i-b i \mathrm{SAG} . \mathrm{ZU}\left[\mathrm{G}_{7}\right]$, no. $51 \mathrm{x}+6$

$\operatorname{Im}_{\mathrm{x}}(\mathrm{DU})-d a-l i k$

1) MUŠEN.DÜ, no. $2: 14$

2) Zé-zé, s. of $I m_{\mathrm{x}}-d a-l i k$ LÚ.MUN ${ }_{\mathrm{x}}$, š $i \breve{S} u-n a-a k-$ pum, no. 9:7 
$\grave{I}-m e-D u r-\grave{u} l$

1) f. of KA-Me-ir, gf. of DINGIR-na-zi-ir, no. 9:5

$I$-[n]a-na-num

1) No. $36: 17$

I-nin-`núm 1

1) X, no. $2: 7$

I-ni-um, see $\grave{E}-n i-u m$

Ip-te-u-um

1) Nos. 6:3 (written Ip-tium) $; 15: 6 ; 27: 4$

I-sá-sá

1) No. $32: 6$

$I \check{s}-b u-a$

1) f. of $T a-t a$, no. $49: 2$

I-su-GI

1) Nos. $20: 1 ; 37: 2 ; 45: 3$

$\grave{I}-z a-z a$

1) S̆E ̌̌S.SAL Li-bur-ri-im, no. $30: 4$

$\grave{I}-z i$-na, see also EZEN

1) Nos. $15: 3 ; 19: 14$

I-zu-ur-ba-s[u]

1) s. of AMA.TU ' $U G U L A{ }^{\urcorner}$

NAGAR, no. 39:10

KA-, see also $P \grave{u}-$

$\mathrm{K}[\mathrm{A}]-b e-l i$

1) $\breve{u} Z Z i-b a$, no. $25: 7$

KA-Ma-ma

1) MA ̌̌s.MA ̌, no. $25: 1$ ${ }^{\mathrm{d}} \mathrm{KA}-\mathrm{Me} e-i r$

1) MA ̌.MAS̆, no. $2: 5$

2) s. of $\bar{I}-m e-D u r-\grave{u l}$, f. of DINGIR-na-zi-ir, no. 9:4 (written KA-Me-ir)

$K i$-za-za

1) No. $17: 12$

KUG.BABBAR-sa

1) Nos. $21: 3 ; 49: 10$
$K u-r u-b a$

1) br. of Ti-ni-na, s. of Ra-biDINGIR, no. 2:10

$L a-a ́ a r a-a b$

1) No. $28: 8$

La-ma-as-tum

1) No. $24 x+4$

$L a-\mathrm{n}[\mathrm{i}]$

1) SAL.LÚ.TÚG, no. $36: 11$ La-wi-ip-tum

1) Nos. 33:28; 50:6 (written Lá-wi-ip-tum)

Li-bur

1) No. $39: 3$

2) AS̆GAB, no. 48:1

Li-bur-ri-im

1) Nos. $30: 5 ; 49: 6$ (written Li-pù-ru-um

Li-li

1) No. $17: 4$

Li-lum

1) No. $23: 1$

$L[u]-b a-[\mathrm{x}]-n a$

1) No. $51 \mathrm{x}+5$

Lu-ga-lu-mu-uk

1) No. $31: 5$

Ma-at-na-hu-um

1) No. $33: 57$

[M]a-má-tim

1) No. $51 \mathrm{x}+10$

Ma-nu-nu

1) No. 10:6

Maš-tum

1) Nos. $18: 1 ; 19: 8$

2) f. of $M a-s ̌ u m$, no. 3:6 $M a-\check{s} u m$

1) Nos. $6: 5 ; 10: 4$ (written $M a$ $\check{s} u[m]) ; 37: 10$

2) s. of Maš-tum, no. 3:5 
$M a-z a-a r-s u$

1) No. $5: 2$

ME-İ $r-r a$

1) d. of Da-KA-KA, no. 49:3 $\mathrm{ME}-K i$-dè

1) No. $33: 25$

$M e-\grave{u}$-sa

1) Nos. $18: 2 ; 19: 6$

Mim-ma-sa

1) No. $37: 5$

Mu-tu-tu

1) No. $1: 10$

$N a-b i-u m$

1) Nos. $7: 21,25 ; 33: 49 ; 45: 10$

2) s. of [....]-tum, no. $36: 2,3$, 7,27

Na-num

1) s. of $Z i-n a-n u m$, no. 29:3

$N a-z i-i r-i-l i$

1) No. $6: 9$

Nin-líl-iš-gi-in

1) No. $33: 48$

NU.BANDA

1) No. $18: 15$

2) br. of $A$-bi-bi, no. $13: 4$ $N u-u m$

1) $U R U D U . \mathrm{X}$, no. $13: 5$

$P \grave{u}-$, see also KA-

$P \grave{u}-\grave{i}-l \grave{\imath}$

1) f. of $A$-dam-u, no. $8: 1$

$P \grave{u}$-pù, see $B u-b u$

$P \grave{u}$ - ${ }^{\mathrm{d}}$ Tišpak

1) No. 4:4 (written $P \grave{u}$ dTišpak)

2) UGULA URU, no. 4:10

\section{Ra-bi-DINGIR}

1) f. of $K u-r u-b a$ and of $T i$ - $\breve{S} u$-BĀD $n i-n a$, no. $2: 13$
$R \bar{e}^{3} \hat{\imath} t u m$

1) Nos. 6:4 (written SIPA-itum) ; 10:3 (written SIPA!tum); 30:10 (written $R i$ - $i_{i}$ - $_{-}$ tum)

$S a-a-m i-i \check{s}$

1) No. $16: 3$

Sa-am-si

1) Nos. 18:4; 19:10 (written $S a-a m-s[i])$

$S a-a-n i-i \check{s}$

1) No. $33: 58$

Sá-lim-me-ni

1) No. $30: 8$

$\mathrm{Sa}$-[ti]-um

1) No. 11:3

SIPA-tum, see $R \bar{e}^{>} \hat{\imath} t u m$

$S i-w[i]-r a$

1) No. $35: 2$

$S u-b a-\grave{e}$

1) f. of $A l-i-l i$, no. 8:3

Su-ba-ri-im

1) f. of Gal-pum, no. 29:2 $S u_{4}-b e-l i$

1) No. 53:12

Su-ni-tum

1) Nos. 17:5, 10; 18:6 (written $\breve{S} u$-ni-tum); 19:11 (written $S u$-n[i-tum]); 21:6 (written Šu-ni-tum); 33:24

2) h. of Um-mi-E $\check{s}_{4}-d a r$, no. $20: 6$

$\check{S} a$-[a]t-be-DINGIR

1) No. $14: 5$

$\check{S} i$-ir-e-si-na

1) f. of $\check{S} u-\mathrm{BA} D$, no. $4: 9$ Šu-a-tum

1) h. of $D a-d a$, no. $20: 3$

1) s. of $\breve{S} i-i r-e-s i-n a$, no. $4: 8$ 
$\check{S} u-E \check{s}_{4}-d a r$

1) No. $33: 45$

Šu-i-li-su

1) Nos. $17: 6 ; 27: 5$

$\check{S} u-M a-m a$

1) No. $14: 2$

2) f. of DINGIR-UR.SAG, no. $12: 9$

Šum-ma-sa

1) No. $9: 18$ (written $\check{S} u[m-m a-s] a)$

2) PA.TE.SI, no. 11:14

Šu-na-ak-pum

1) PA.TE.SI, no. 14:8 (written Š $u-n a-[a k]-p u m)$

2) $Z \dot{e}-z \dot{e}, \mathrm{~s}$. of $I m_{\mathrm{x}}-d a-l i k \mathrm{LU}$. $\mathrm{MUN}_{\mathrm{x}}, \quad \check{s} i \check{S} u-n a-a k-p u m$, no. $9: 8$

$\check{S} u-N a-n a$

1) s. of Al-lum, no. 9:1

$\check{S} u$-ni-tum, see $S u$-ni-tum

$\breve{S} u$-um

1) Nos. $10: 2 ; 17: 1 ; 19: 3$ (written $\breve{S} u-u[m]) ; 27: 3 ; 33: 39$

2) IB, no. $9: 11$

$T a b-i-l i$

1) No. $35: 6$

Tab-ni

1) Nos. $17: 11$ (written Tab-ni); 23:11; 45:12 (written Tabni)

$T a b-s i-g a$

1) E-gi šu Tab-si-ga, no. $3: 2$ Ta-ta

1) d. of $I \check{s}-b u-a$, no. $49: 1$ TE.NA-DINGIR

1) No. $18: 17$

Te-si-tum

1) No. $35: 4$
Ti-ni-na

1) br. of $K u-r u-b a$, s. of $R a-b i-$ DINGIR, no. 2:11

$\hat{U}-a$

1) Nos. $17: 2 ; 18: 10 ; 19: 1 ; 27: 6$

UD-kum

1) No. $5: 8$

$U m-[\ldots]$

1) f. of $I-d a-r a-a[k]$, no. 49 rev. $\mathrm{x}+2$

Um-ma-ni

1) No. $23: 2$

$U m-m i-E \check{s}_{4}-d a r$

1) Nos. $18: 5 ; 19: 7 ; 37: 4 ; 50: 2$

2) w. of Su-ni-tum, no. $20: 7$

$U m-m i-m i$

1) No. $33: 59$

$U r-S u-d a$

1) No. $5: 7$

UR.UR

1) EDIN, s. of $P \grave{u}-p \grave{u}, \quad \check{s} i$ UR.UR

${ }^{\mathrm{d}}$ UTU-É, see also following name

1) UGULA.[. . . .]?, nos. 18:3; 19:9

${ }^{d}$ UTU-SA, see also preceding name

1) No. $33: 40$

$W a-z u-z u$, see also $B a$-šu-šu

1) No. $50: 7$

$Z \dot{e}-z \dot{e}$

1) s. of $I m_{\mathrm{x}}-d a-l i k$ LÚ.MUN $\mathrm{N}_{\mathrm{x}}$, š $i \breve{S} u-n a-a k-p u m$, no. 9:6

$Z i-b a$

1) K[A]-be-lí šu $Z i$-ba, no. $25: 8$ $Z i$-na-num

1) f. of $N a-n u m$, no. $29: 4$

Zum-ti

1) No. $14: 1$ 
$Z u-z u$

1) Nos. $1: 2 ; 23: 8$ (written $\mathrm{Zu}$ zu) ; $33: 46 ; 42: 4 ; 47: 7 ; 50: 8$

2) ARÁD ${ }^{d}$ Innin, no. 8:4 [.... $]$-lum

1) No. $36: 14$ ....-na-bí

1) f. of $A-n i n-u$, no. $18: 21$ [......-ra-tum

1) No. $11: 7$

$\mathrm{X}-s u-d u-u m$

1) No. $5: 13$

[....]-tum

1) f. of $N a-b i-u m$, no. $36: 28$

\section{DIVINE NAMES}

Dur-ùl, deified geographic name; cf. personal name $\grave{I}-m e-D u r-\grave{u} l$ $\hat{E}$-a, cf. personal name $\hat{E}-a-i-l i ́$

${ }^{\mathrm{d}} \mathrm{EN} . Z \mathrm{ZU}$, cf. personal name $I-d a-{ }^{\mathrm{d}} \mathrm{EN} . Z \mathrm{ZU}$

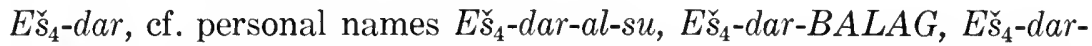

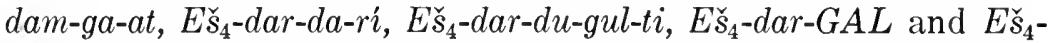

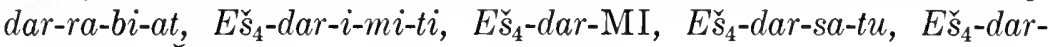
UR.SAG, $\check{S} u-E \check{s}_{4}-d a r$, and $U m-m i-E \check{s}_{4}-d a r$

$G a-z u r_{\mathrm{x}}$, deified geographic name; cf. personal name AMA-Ga-zur (SAG)

${ }^{\mathrm{d}}$ Innin, no. 8:4. Cf. also personal names ARÁD- ${ }^{\mathrm{d}}$ Innin and GEMÉ${ }^{\mathrm{d}}$ Innin

$\grave{I} r$-ra, cf. personal name ME-İr-ra

$K i$-dè, deified geographic name; cf. personal name ME- $K i$-dè

$M a-m a$, cf. personal names KA-Ma-ma and $\check{S} u-M a-m a$

$M e-i r$, cf. personal names ${ }^{\mathrm{d}} \mathrm{KA}-\mathrm{Me}$-ir, KA-Me-ir

$N a-n a$, cf. personal name $\check{S} u-N a-n a$

Nin-líl, cf. personal name Nin-líl-iš-gi-in

$S u-d a$, cf. personal name $U r-S u-d a$

${ }^{\mathrm{d}}$ Tišpak, nos. 7:26; 51 rev. $\mathrm{x}+2$. Cf. also personal names ARÁD-

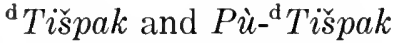

$T u$-tu, deified geographic name; cf. personal name 'ARÁD'-Tu-tu

\section{GEOGRAPHIC NAMES}

$A-g a-d \grave{e}^{\mathrm{KI}}$, nos. $9: 16 ; 31: 4$

Ban-ga ${ }^{\mathrm{KI}}$, no. $33: 46$

Dur-ùl, deified geographic name; cf. personal name $\grave{I}$-me-Dur-ùl E-la-me-tum, gentilic personal name 
$G a-z u r_{\mathrm{x}}$, deified geographic name; cf. personal name AMA-Ga-zur (SAG)

Ib-ri-me, no. 33:32

$K i$-de $e^{\mathrm{KI}}$, no. 33:50. URU-Gi-tim, no. 25:9. Cf. also deified geographic name in personal name ME-Ki $i$-dè

Su-ba-rí-im, gentilic personal name

$T u-t u$, deified geographic name; cf. personal name 'ARĀD'-Tu-tu 


\section{Indices of Text and Museum Numbers}

Text No, Museum No. Text No. Museum No. Text No. Museum No.

$\begin{array}{rrrrrr}1 & 229237 & 19 & 229204 & 37 & 229250 \\ 2 & 229227 & 20 & 229210 & 38 & 229214 \\ 3 & 229230 & 21 & 229208 & 39 & 229216 \\ 4 & 229205 & 22 & 229224 & 40 & 229251 \\ 5 & 229238 & 23 & 229236 & 41 & 229221 \\ 6 & 229245 & 24 & 229242 & 42 & 229207 \\ 7 & 229246 & 25 & 229231 & 43 & 229209 \\ 8 & 229254 & 26 & 229249 & 44 & 229213 \\ 9 & 229206 & 27 & 229218 & 45 & 229225 \\ 10 & 229233 & 28 & 229219 & & +229229 \\ 11 & 229220 & 29 & 229235 & 46 & 229240 \\ 12 & 229222 & 30 & 229228 & 47 & 229217 \\ 13 & 229243 & 31 & 229234 & 48 & 229223 \\ 14 & 229232 & 32 & 229239 & 49 & 229203 \\ 15 & 229215 & 33 & 229201 & 50 & 229247 \\ 16 & 229226 & 34 & 229202 & 51 & 229244 \\ 17 & 229212 & 35 & 229241 & 52 & 229252 \\ 18 & 229211 & 36 & 229248 & 53 & 229253\end{array}$

Museum No. Text No. Museum No. Text No. Museum No. Text No.

$\begin{array}{rrlrrr}229201 & 33 & 229220 & 11 & 229237 & 1 \\ 229202 & 34 & 229221 & 41 & 229238 & 5 \\ 229203 & 49 & 229222 & 12 & 229239 & 32 \\ 229204 & 19 & 229223 & 48 & 229240 & 46 \\ 229205 & 4 & 229224 & 22 & 229241 & 35 \\ 229206 & 9 & 229225 & 45 & 229242 & 24 \\ 229207 & 42 & +229229 & & 229243 & 13 \\ 229208 & 21 & 229226 & 16 & 229244 & 51 \\ 229209 & 43 & 229227 & 2 & 229245 & 6 \\ 229210 & 20 & 229228 & 30 & 229246 & 7 \\ 229211 & 18 & 229229 & 45 & 229247 & 50 \\ 229212 & 17 & \text { joined to } 229225 & 229248 & 36 \\ 229213 & 44 & 229230 & 3 & 229249 & 26 \\ 229214 & 38 & 229231 & 25 & 229250 & 37 \\ 229215 & 15 & 229232 & 14 & 229251 & 40 \\ 229216 & 39 & 229233 & 10 & 229252 & 52 \\ 229217 & 47 & 229234 & 31 & 229253 & 53 \\ 229218 & 27 & 229235 & 29 & 229254 & 8 \\ 229219 & 28 & 229236 & 23 & & \end{array}$




\section{Abbreviations of Books and Periodicals}

AHWB Delitzsch, Friedrich, Assyrisches Handwörterbuch (Leipzig, 1896).

AJSL American Journal of Semitic Languages and Literatures (Chicago, etc., 1884-).

$A O F$

Archiv für Orientforschung III- (Berlin, 1926-).

$A O T U$

Altorientalische Texte und Untersuchungen (Leiden, 1917-21).

AS

Chicago. University. Oriental Institute. Assyriological Studies (Chicago, 1931-).

AS no. 1

MeIssner, BRUno, Beiträge zum assyrischen Wörterbuch I (1931).

AS no. 4

MeISSNER, BRUNo, Beiträge zum assyrischen Wörterbuch II (1932).

AS no. 9 Poebel, Arno, Studies in Akkadian Grammar (1939).

AS no. 11 JaCoBsen, Thorkild, The Sumerian King List (1939).

AS no. 22 Gelb, IGNACE J., Hurrians and Subarians (1944).

$B B$

Ungnad, ARthur, Babylonische Briefe aus der Zeit der Hammurapi-Dynastie (Leipzig, 1914).

$B E$

$B E \mathrm{I}$

Pennsylvania. University. The Babylonian Expedition of the University of Pennsylvania. Series A: Cuneiform Texts (Philadelphia, 1893-1914).

Hilprecht, H. V., Old Babylonian Inscriptions, Chiefly from Nippur (1893-96).

BE III 1 Myhrman, D. W., Sumerian Administrative Documents Dated in the Reigns of the Kings of the Second Dynasty of Ur (1910).

BIN Babylonian Inscriptions in the Collection of James B. Nies (New Haven, Conn., 1917-).

BIN IV Clay, Albert T., Letters and Transactions from Cappadocia (1927).

BIN V Hackmann, George Gottlob, Temple Documents of the Third Dynasty of Ur from Umma (1937).

CT Cuneiform Texts from Babylonian Tablets, etc., in the British Museum (London, 1896-).

EBPN Ranke, Hermann, Early Babylonian Personal Names (Philadelphia, 1905).

HSS Harvard Semitic Series (Cambridge, Mass., 1912-). 
$\operatorname{HSS} \mathrm{X}$

$I T T$

ITT I

ITT II 1-2

ITT III

ITT V

$M A D$

$M A D$ I

$M A D$ II

Mém.

Mém. II

Mém. XIV

Mém. XVIII

Mém. XXII

Mém. XXIV

Meek, Theophile James, Old Akkadian, Sumerian, and Cappadocian Texts from Nuzi (1935).

Mission française en Chaldée. Inventaire des tablettes de Tello conservées au Musée Impérial Ottoman (Paris, 1910-21).

Thureau-Dangin, Fr., Textes de l'époque d'Agadé (1910).

Genoulllac, Henri De, Textes de l'époque d'Agadé et de l'époque d'Ur (1910-11).

Genouillac, Henri DE, Textes de l'époque d'Ur. Deuxième partie (1912).

Genouillac, Henri DE, Époque présargonique, époque d'Agadé, époque d'Ur (1921).

Chicago. University. Oriental Institute. Materials for the Assyrian Dictionary (Chicago, 1951-).

Gelb, I. J., Sargonic Texts from the Diyala Region (1952).

GelB, I. J., Old Akkadian Writing and Grammar (1952).

France. Délégation en Perse. Mémoires (Paris, 1900-).

Scheil, V., Textes élamites-sémitiques. Première série (1900).

SCheIL, V. and LEGraIn, LÉon, Textes élamites-sémitiques. Cinquième série (1913).

Dossin, Georges, Autres textes sumériens et accadiens (1927).

Scheil, V., Actes juridiques susiens (1930).

Scheil, V., Actes juridiques susiens. Inscriptions des Achéménides (1933).

Mém. XXVII Meer, P. E. van Der, Textes scolaires de Suse (1935).

Mém. XXVIII ScheiL, V., Mélanges épigraphiques (1939).

MVAG Berlin. Mitteilungen der Vorderasiatisch-Aegyptischen Gesellschaft (Berlin, 1896-1908; Leipzig, 1909-).

$O I P$

Chicago. University. Oriental Institute. Oriental Institute Publications (Chicago, 1924-).

OIP XIV

LUCKENBILl, DANIEL DAVID, Inscriptions from Adab (1930).

OIP XXVII

GELB, IGNACE J., Inscriptions from Alishar and Vicinity (1935).

OIP XLIII

Frankfort, Henri; Lloyd, Seton; and Jacobsen, Thorkild, The Gimilsin Temple and the Palace of the Rulers at Tell Asmar (1940).

oip lvil Gelb, Ignace J.; Purves, Pierre M.; and Macrae, Allan A., Nuzi Personal Names (1943).

$O L Z$

Orientalistische Literaturzeitung (Berlin, 1898-1908; Leipzig, 1909-).

$P B S$

Pennsylvania. University. University Museum. Publications of the Babylonian Section (Philadelphia, 1911-). 
PBS II 1 Clay, Albert T., Business Documents of Murashu Sons of Nippur, Dated in the Reign of Darius II (1912).

PBS V PoEbel, ARno, Historical and Grammatical Texts (1914).

PBS IX 1 Barton, George A., Sumerian Business and Administrative Documents from the Earliest Times to the Dynasty of Agade (1915).

PNCP Clay, Albert T., Personal Names from Cuneiform Inscriptions of the Cassite Period (New Haven, 1912).

$R$

RA Revue d'assyriologie et d'archéologie orientale (Paris, 1884-).

RTC Thureau-Dangin, Françors, Recueil de tablettes chaldéennes (Paris, 1903).

SAKI ThUREAU-DangIN, FrançoIs, Die sumerischen und akkadischen Königsinschriften ("Vorderasiatische Bibliothek," Bd. I, Abt. 1; Leipzig, 1907).

$\check{S} L \quad$ DeImel, ANTON, Šumerisches Lexikon (Roma, 1930-).

TMH Texte und Materialien der Frau Professor Hilprecht Collection of Babylonian Antiquities im Eigentum der Universität Jena (Leipzig, 1932-).

TMH V PoHL, Alfred, Vorsargonische und sargonische Wirtschaftstexte (1935).

TMH N.F.I/II PohL, ALFRED, Rechts- und Verwaltungsurkunden der III. Dynastie von $U r$ (1937).

VAS Berlin. Königliche Museen. Vorderasiatische Abteilung. Vorderasiatische Schriftdenkmäler (Leipzig, 1907-17).

WZKM Wiener Zeitschrift für die Kunde des Morgenlandes (Wien, 1887-).

$Z A \quad Z$ Zitschrift für Assyriologie und verwandte Gebiete (Leipzig, 1886). 
Publication 748 






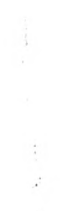



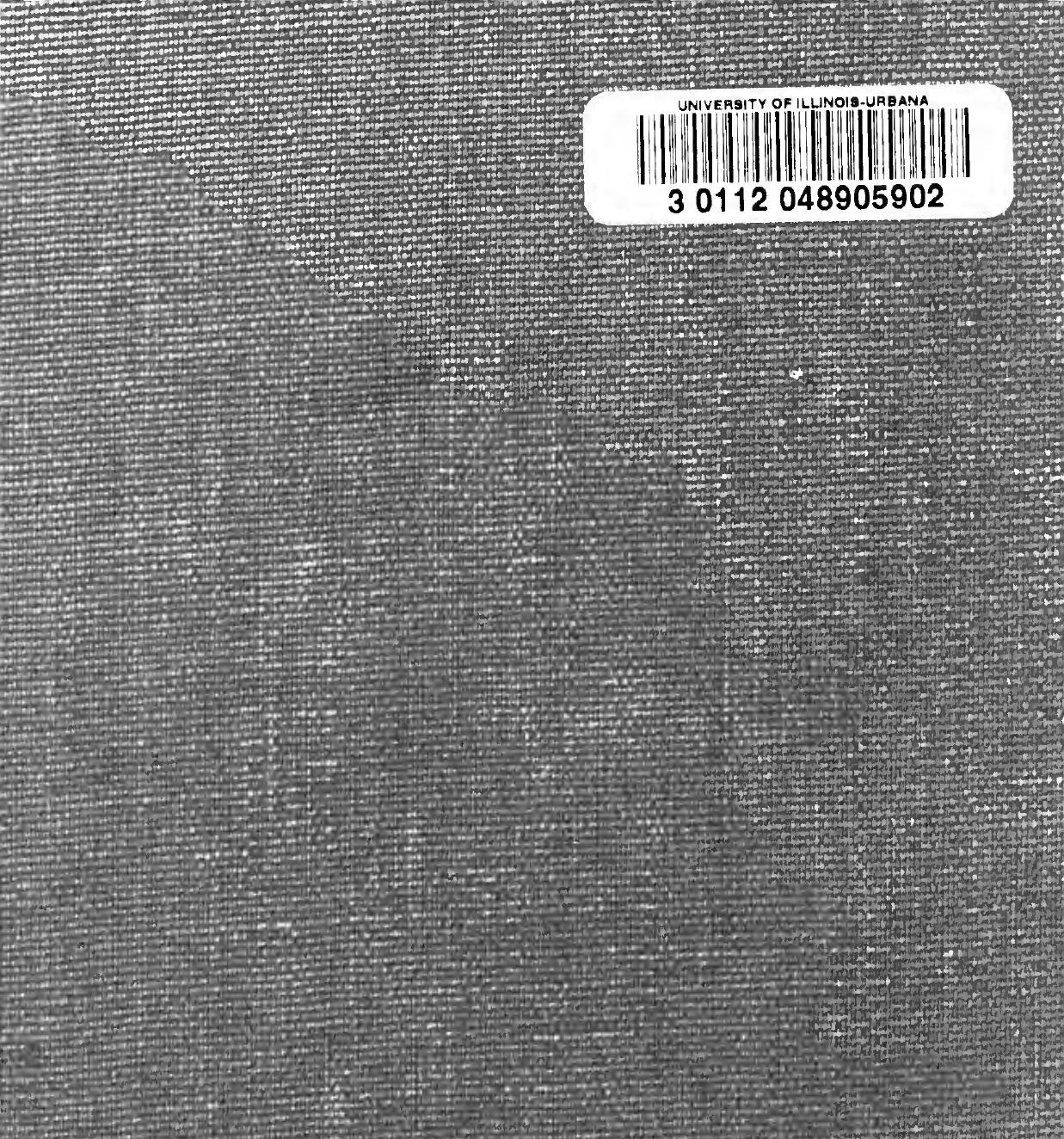